\title{
Media Coverage of the Federal Election of 2008 and the
}

\section{Two Solitudes at the Public Broadcaster}

\author{
By Amanda Pfeffer
}

A thesis submitted to the Faculty of Graduate Studies and Research in partial fulfillment of the requirements for the degree of

Master of Journalism

Carleton University

Ottawa, Canada

(C)2011, Amanda Pfeffer 
Library and Archives

Canada

Published Heritage

Branch

395 Wellington Street Ottawa ON K1A ON4 Canada
Bibliothèque et

Archives Canada

Direction du

Patrimoine de l'édition

395 , rue Wellington

Ottawa ON K1A ON4

Canada
Your file Votre référence

ISBN: 978-0-494-83178-6

Our file Notre référence

ISBN: 978-0-494-83178-6
NOTICE:

The author has granted a nonexclusive license allowing Library and Archives Canada to reproduce, publish, archive, preserve, conserve, communicate to the public by telecommunication or on the Internet, loan, distribute and sell theses worldwide, for commercial or noncommercial purposes, in microform, paper, electronic and/or any other formats.

The author retains copyright ownership and moral rights in this thesis. Neither the thesis nor substantial extracts from it may be printed or otherwise reproduced without the author's permission.
AVIS:

L'auteur a accordé une licence non exclusive permettant à la Bibliothèque et Archives Canada de reproduire, publier, archiver, sauvegarder, conserver, transmettre au public par télécommunication ou par l'Internet, prêter, distribuer et vendre des thèses partout dans le monde, à des fins commerciales ou autres, sur support microforme, papier, électronique et/ou autres formats.

L'auteur conserve la propriété du droit d'auteur et des droits moraux qui protège cette thèse. $\mathrm{Ni}$ la thèse ni des extraits substantiels de celle-ci ne doivent être imprimés ou autrement reproduits sans son autorisation.
In compliance with the Canadian Privacy Act some supporting forms may have been removed from this thesis.

While these forms may be included in the document page count, their removal does not represent any loss of content from the thesis.
Conformément à la loi canadienne sur la protection de la vie privée, quelques formulaires secondaires ont été enlevés de cette thèse.

Bien que ces formulaires aient inclus dans la pagination, il n'y aura aucun contenu manquant. 


\begin{abstract}
The Canadian Broadcasting Corporation began as a nation-building project with a mandate to foster a "national consciousness and identity." Its founders hoped the CBC would play a role in creating that "we feeling" among members of Canada's two solitudes. Since then, however, the Corporation has been accused of failing in that mandate, contributing instead to linguistic cleavage. This thesis considers whether the Corporation is still failing today, by comparing media coverage of the 2008 election campaign through the nightly national newscasts of the French and English services. This thesis offers the historical and social context, and finally, considers whether the $\mathrm{CBC}$ lives up to its challenging mandate.
\end{abstract}




\section{Acknowledgments}

I would like to thank the people who supported this work, in particular, those who generously gave their time and contributed ideas for the advancement of public service journalism. I would also like to thank my thesis advisor, Chris Waddell whose encouragement and enduring patience led to the successful completion of this work. Finally, I'd like to thank my family who believed in me throughout.

Amanda Pfeffer. 


\section{Table of Contents}

Chapter 1 Introduction 1

11 One Broadcaster Two Services $\quad 4$

12 Elections and TV News $\quad 7$

13 The Role of Public Broadcasting 8

14 Canada's Unique Publıc Broadcaster $\quad 15$

$\begin{array}{lr}15 \text { This Thesis } & 20\end{array}$

Chapter 2· Canada and the Challenge of Nationalism 23

21 Theories of Nationalism and the Canadian Reality 25

22 The Role of the Public Broadcaster French vs English 29

23 The Paradox of the Mandate 33

Chapter 3- The Public Broadcaster and Linguistic Cleavage in Canada 35

31 Clashing Myths The Story of Two Canadas 39

32 The Corporation and Political Cleavage 41

33 The Media and Canadian Federal Electıon Campaigns 48

34 The Issue of Culture in Quebec $\quad 51$

Chapter 4 Distinct Societies/Distinct Journalısts 56

41 Medıa 'Gatekeepıng' and 'Agenda Settıng' 68

Chapter 5: Coverage of the 2008 Federal Election Campaign 69

51 Television Coverage Le Telejournal and The National 74

522008 by the Numbers $\quad 75$

53 Section One Campaıgn Begıns $\quad 80$

54 Section Two "Culture en Perıl" 90

55 Section Three The Road to Election Day 102

$\begin{array}{lr}56 \text { The Lead Project } & 112\end{array}$

Chapter 6: Analysis of the 2008 Campaign Coverage $\quad 116$

61 Who's Holdıng the Fiddle? 118

62 Quebec - Ottawa Relatıons $\quad 120$

63 The Meanıng of Culture durıng the 2008 Electıon Campaign 122

64 Treatment of the Bloc Quebecols $\quad 128$

65 The Conservative Party and the Message $\quad 133$

$\begin{array}{lr}66 \text { In General } & 136\end{array}$

$\begin{array}{lr}\text { Chapter 7: Conclusion } & 138\end{array}$

$\begin{array}{lr}\text { Bibliography } & 157\end{array}$ 
Tables, Figures, Graphs

$\begin{array}{ll}\text { Table } 1 \text { Party Standıngs } & 70\end{array}$

Table 2 Coverage of the Parties $\quad 78$

Table 3 Economic Crisis durıng the Campaign 2008

$\begin{array}{lr}\text { Table } 4 \text { Ratıngs } & 146\end{array}$

Figure 1 Polls durıng the Campaign $\quad 79$

$\begin{array}{lr}\text { Graphic } 1 \text { The Lead Project } & 114\end{array}$ 


\section{Preface}

The motivation for this thesis emerged following 18 years working as an English journalist in the newsrooms of the Canadian Broadcasting Corporation. I was attracted to public broadcasting as a journalism student at Concordia University; it appealed to my ideals about journalism and its democratic role as a public service helping Canadian citizens make better choices about the communities in which they live. I'm not alone. I've had the chance to work with journalists both at the French and English services who I admire for their unbending dedication to public broadcasting and the people of Canada; really.

I began my career in the Montreal local television newsroom in 1993 and since that time working for the $\mathrm{CBC}$ has given me a unique and often exciting opportunity to tell stories for and about Canadians from coast to coast. I've reported for newsrooms in Montreal, Vancouver, Fredericton, Ottawa and Quebec City. I've had the chance to cover municipal, provincial and federal elections; I have covered political stories on Parliament Hill, the National Assembly and the New Brunswick legislature (the only bilingual legislature besides Parliament, by the way.) As a Montrealer, it was easy to identify with my French-speaking colleagues working outside Quebec. Covering news, particularly political news, is very different if you are reporting as a member of the majority-versus the minority-language group in a region. As a symbol of this power imbalance, the first questions asked at a media scrum in the National Assembly are always in French. On Parliament Hill, it is rarely the case; in Vancouver, almost never. It affects how fast sources call you back, or who the sources choose when they leak a 
story. It affects how easy it is to get someone accountable to speak to your community members in their own language.

I grew up in Montreal as part of the English minority during a period of tension and political uncertainty. I started school under the newly elected Parti Québécois when students needed to apply for eligibility certificates to attend English public school. On the eve of the 1980 Quebec referendum on sovereignty, I remember our little 12year-old hands put to work making the black and white NO buttons - factory assembly style -- on the cafeteria tables during class time. With so much at stake, not unlike our French-speaking neighbours, political debate flourished in households of English Quebeckers about what it means to be Canadian and about the future of Canada. Our discussions - as you can imagine - were very different from those taking place in the homes of the Francophone families down the street.

It was both my own identity as a member of the English minority in Quebec and my identification with my French colleagues at the $\mathrm{CBC}$ that made me sensitive to examples of linguistic cleavage in news coverage - particularly during political discourse.

It has always struck me standing beside my French colleagues - whether in the New Brunswick legislature or the National Assembly or the Centre Block on Parliament Hill - that the questions we ask are not the same; our stories are focused on different issues. While we share our idealistic views about working for the public broadcaster, it does not result in shared narratives. In fact, we share more content with our samelanguage private media competitors than with each other. The cultural environments of 
the communities we serve seem to shape the stories we tell. This thesis tries to examine not just how Canada's two media systems differ, but why. In this way, I hope this discussion contributes to the larger debate focused on developing opportunities for mutual understanding and ultimately bringing Canada's two solitudes a little closer together. 


\section{Chapter 1: Introduction}

In September 2008, the Conservative leader and Prime Minister of Canada, Stephen Harper asked the Governor General to dissolve the $39^{\text {th }}$ Parliament and hold an election the following month. Canadıans don't often tell pollsters they look forward to elections, but it's fair to say the public appetite for this particular vote could hardly be lower. ${ }^{1}$ It would be the third federal election in just four years. Canadians had already elected two consecutive minority governments. In a bid to secure more political stability, the Conservative government had even come up with a law fixing election dates; the first was not due for another year.

Yet, Stephen Harper initiated this election despite his own legislation. To be fair, the fixed election date legislation did not extinguish that right. ${ }^{2}$ His explanation was that the current minority Parliament was "dysfunctional." Stephen Harper sought "a more stable" government and ultimately, a majority of seats in Parliament. ${ }^{3}$ Just a few days into the campaign, on September 13, 2008, a Toronto Star-Angus Reid poll suggested Canadians were ready to give the Conservatives what they wanted. ${ }^{4}$

\footnotetext{
'Voter turn-out on election day reached an histonc low of $588 \%$ "Voter Turnout at Federal Electıons and Referendums," Elections Canada, accessed June 11, 2011 , http / www elections ca/content aspx"section=ele\&dit=turn\&document=-index\&lang=e

${ }^{2}$ The non-profit group Democracy Watch took the issue to court and lost at the Federal Court and Federal Court of Appeal (the Supreme Court of Canada refused to hear the case) The group argued the 2008 election initiated by the Prime Minister contravened the spirit of the new fixed date election legislation The courts found the legislation was sufficiently "vague" and thus did not restrict the Prime Minister from initiatıng the timing of an election "Top court won't hear fixed election date case," CBC, January 20, 2011, accessed June 8, 2011, http //www cbc ca/news/canada/story/2011/01/20/fixed-election-scoc html

${ }^{3}$ This is not to say that minorities are necessarly bad for citizens Peter Russell wrote a book following the Conservatıves' first minority mandate, argung for how mınority Parliaments can make for good government Peter H Russell, Two Cheers for Minority Government The Evolution of Canadian Parliamentary Democracy (Toronto Emond Montgomery Publications, 2008)

4 "What would PM do with majority?" The Toronto Star, September 13, 2008, accessed June 5, 2011, http /www angus-reid com/wp-content/uploads/archıved-pdf/star majorıty pdf
} 
But campaigns are unpredictable things.

Thirty-six days and $\$ 300$ million later, the Conservatives came up short in 2008 , and once again, Canadians elected a minority government. The Conservative Party needed 10 more seats to attain a majority, and as this thesis will show, party strategists had hoped those seats would come from Quebec. The party had invested enormous amounts of public funds and political capital during the previous mandate trying to win support in Quebec. ${ }^{5}$ Toronto Star columnist Chantal Hébert had even penned a book called French Kiss: Stephen Harper's Blind Date with Quebec about the effort (and success) of the federal Conservatives to woo Quebec support. ${ }^{6}$

But by election day, Quebeckers didn't come through for the Conservatives. "Quebec (gave) us the one-finger salute," 7 suggested an editorial in the Victoria Times Colonist. Despite all the courting by the Conservative government, two thirds of Quebec seats -- 49 out of 75 - went to the Bloc Québécois: a regionalist party with a constitution calling for the secession of Quebec from Canada. The Conservatives hung onto the 10 seats they had gained in Quebec the previous election: "It was enough for them to save the furniture," wrote former Conservative speech writer and strategist L.

\footnotetext{
"Among the "outreach" work done by the Conservatıves to endear Quebec voters, the Conservatıves produced a motion passed in the House of Commons on November 27, 2006 declarıng "the Québécois form a nation withın a united Canada" The Conservative government also gave Quebec a gieater role as part of the Canadıan delegation to UNESCO Perhaps more signıficantly, however, the Harper government addressed the Quebec assertıon that the federal government had been short changing the province, calling it a "fiscal imbalance" in transfer payments The Conservatives added $\$ 36$ billion in new income to the provincial government.

${ }^{6}$ Chantal Hébert, French Kiss Stephen Harper's Blind Date with Quebec (Toronto: Alfred A. Knopf Canada, 2007)

7 "Harper must manage rising antı-Quebec backlash. How many times have we heard the question: What does Quebec want?" Victorla Times Colonist, October 22, 2008, accessed July 20, 2011 , http://www canada com/victoriatımescolonist/columnists/story html?ıd $=53 \mathrm{fc} 2 \mathrm{f} 65-0 \mathrm{~b} 46-4159-\mathrm{badb}-$ $\underline{\mathrm{a} 160 \mathrm{afc} 677 \mathrm{c} 0}$
} 
Ian MacDonald ${ }^{8}$ in the days following the election: "There, but for Quebec, went a majority. And Stephen Harper, who can do the math on the back of an envelope, knows it." ${ }^{9}$ He further explained:

“Harper, who loves tactics, got played by Gilles Duceppe, the Bloc Québécois and the Quebec media. What had been a referendum on Harper delivering the goods for Quebec and the Bloc having had its day in Ottawa was transformed within days into a referendum on Harper not sharing Quebec values and the Bloc defending them. Harper's Quebec ballot question got flipped to a ballot question on identity that Duceppe couldn't lose."

As MacDonald suggests, something happened during the 36 days of the 2008

campaign that changed the fortunes of the Conservatives in (the mostly French-

speaking) Quebec, despite growing support in the rest of (the mostly English-speaking)

Canada.

The clues lie in the mediated discourse - the news coverage - that unfolded before English and French audiences. This thesis looks for those clues through an analysis of coverage by the national evening newscasts of the public broadcaster - Le Téléjournal and The National - over the 36 days of the campaign.

There are compelling reasons to watch the campaign coverage of 2008 through the lens of the public broadcaster. For one thing, the Canadian Broadcasting Corporation is one of the few national networks in the world operating two separate language services under the same roof. For another - and perhaps most significant for the purposes of this thesis - the public broadcaster operates under a legislated mandate

\footnotetext{
${ }^{8}$ MacDonald was chief speech writer for Prime Minıster Brian Mulroney from 1985-1988

${ }^{9}$ L. Ian MacDonald, "The woomg of Quebec will recommence at dawn," The Natronal Post, October 16 , 2008.

${ }^{10}$ MacDonald, "The wooing"
} 
to "foster shared national consciousness and identıty;" in other words, a mandate that asks its programmers to help bridge the two solitudes in Canada.

This thesis will show, however, there were significant divergences along linguistıc lines taking place during the political coverage of the 2008 election campaign. That these divergences existed at the public broadcaster underscores the significance of the two solitudes within Canada's dual medıa system. Linguistic cleavage has been a consistent theme during coverage of Canadian federal politics, and so this thesis will also consider the social and historical context leading up to the campaign - a context lınked to the story of Canada.

\section{One Broadcaster - Two Services}

There are several compelling reasons, as mentioned, to undertake this analysis of coverage through the French and English news programs of the Canadian Broadcasting Corporation. The French- and English-language services ${ }^{12}$ are owned and paid for by the people of Canada. From its inception, the $\mathrm{CBC}^{\prime}$ s founders hoped a public broadcasting service would be a unifying force for Canadians, ${ }^{13}$ and in a very deliberate way, contribute to a sense of natıonhood. Indeed, while the Broadcasting Act today demands public broadcasting provide services that meet the respective needs of both

\footnotetext{
11 "Program Polıcıes - CBC/Radı-Canada Mandate," CBC/Radı-Canada, accessed November 12, 2008 , http / www cbe radio-canada ca/docs/policies/piogram/mandate shtml

${ }^{12}$ The French service in this thesis will be referred to as both Radio-Canada and SRC (Societe RadioCanada)

${ }^{13}$ Sir John Aird, "Report of the Royal Commission on Radıo Broadcasting," in Documents of Canadian Broadcasting, ed. Roger Bird (Ottawa, Carleton University Press, 1988) 44 The report says "In a country of the vast geographical dimensions of Canada, broadcastıng will undoubtedly become a force in fostering national spirit and interpretıng national consciousness"
} 
the English and French communities, ${ }^{14}$ it also commits the $\mathrm{CBC}$ "to contribute to shared national consciousness and identity."

The political discourse during federal electıon campaigns provides an opportunity to examine how well the public broadcaster lives up to the expectations of its challenging mandate. There have been accusatıons in the past the $\mathrm{CBC}$ has failed to keep its commitment at critical times during some of Canada's most divisive crises. Accusations of media bias during coverage of the Meech Lake Accord constitutional negotiations led the corporation to adopt new rigorous monitorıng of political campaign coverage as described in the CBC's Journalistic Standards and Practices: $:^{15}$

\begin{abstract}
"Particular care must be given to information programs during election or referendum campaigns. These series require close and meticulous attention to overall political balance. Quantitative checks are normally employed for guidance during election or referendum campaigns. Such quantitative checks must be supplemented by the exercise of qualitative judgments so that imbalance does not occur through the manipulation of events."16
\end{abstract}

Therefore, there exists within the Canadian Broadcasting Corporation two

services covering the same story, often sharing the same resources, ${ }^{17}$ using the same

\footnotetext{
14 "Progiam Polıcies" The mandate says "programmıng by the Corporation should be in English and in French, reflecting the different needs and circumstances of each official language community, including the particular needs and circumstances of English and French linguistic minorities "

${ }^{15}$ Accusations of bias in the Fiench service coverage during the Meech Lake constitutional negotiations, and the new rules are described in Kathryn-Jane Hazel, "The Media and Nationalısm in Quebec A Complex Relationship," Journalism Studies 2, no 1, (2001) 104, also David Taras, "The Mass Media and Political Crisis Reportıng Canada's Constitutional Struggles," Canadian Journal of Communication 18 , no 2, Toronto (Spring, 1993) 131

16 "CBC Journalıstıc Standards and Practıces," CBC/Radıo-Canada, accessed November 22, 2008, http //www cbc radio-canada ca/docs/policies/journalistıc/xml/policies asp

${ }^{17}$ Sharing resources has always taken place to some extent, but the trend has accelerated with shrinking budgets, and improved technology over the last decade The newsrooms of the CBC and Radio-Canada will make formal and informal arrangements to share 1esources both while gathering in the field as well as post-gathering For example, reporters will sometımes gather stones together with one team (a reporter and camera operator) covering off one interview and another coverıng something else, asking questions for
} 
rules of coverage, and guided by the same mandate "to contribute to a shared national consciousness and identity." Yet, consistently, they produce very different content. This thesis will show that despite all that the two services share, how they differ is profound and it relates to their roles as agenda-setters.

"Agenda setting" describes how news organizations manipulate news outputs in the selection of news. In this way, theorists suggest the media does not necessarily tell audiences how to think, but "what to think about."18 Significant to this thesis, news rooms also operate within a defined cultural context or environment. ${ }^{19}$ In Canada, the public broadcaster's two language services, though they may even share the same physical space, ${ }^{20}$ operate newsrooms in separate cultural environments. These environments shape journalists' frames of reference in determining "what is news" for their respective audiences. This results in coverage dynamics that diverge particularly during political campaigns. This inquiry will demonstrate how coverage of the federal election campaign of 2008 by the French and English services did not "contribute to shared national consciousness and identity," but rather, helped contribute to Canada's two solitudes.

\footnotetext{
each other, and sharıng ımages Thıs also takes place after interviews and images are shot, where program peisonnel, including radio and internet reporters and writers, will search through field tapes through the shared digital server system Consider that this level of sharng suggests that differences in reporting by journalists occur despite sometimes having full knowledge of the other seivice reporter's angle or approach

${ }_{18}$ Paul W Nesbitt-Larking, Polttics, Soctety, and the Medta, (Peterborough, Ont Broadview Press, 2001)

${ }^{19}$ Walter Soderlund, Walter Romanow, Donald Briggs and Ronald Wagenberg, Media \& Electlons $m$ Canada (Toronto. Holt, Rinehart and Winston of Canada Ltd, 1984) 29

${ }^{20}$ Many of CBC/SRC locations have integrated, along with radio and television personnel, French and English newsrooms In Ottawa, for instance, the English and French radio and television newsrooms have moved to share the same physical space.
} 
What impact this dual coverage actually has on election outcomes is difficult to gauge and would require further examınatıon of how audıences make their electoral choices This is not the focus of this thesis But certainly the outcome of this particular election does reflect the contınuing entrenchment of Canada's dual society, where the media - even those mandated to build bridges -- seem unable to play a role as a social Integrator.

\section{Elections and TV News}

Canadıans stıll report receiving most of their election information from televisıon news. ${ }^{21}$ The two programs featured in thıs analysıs Le Téléjournal, and The Natıonal are sıgnificant contributors to that process. Pollıng data from the 2006 campaign suggested more Englısh speakers (38 per cent) relıed on the CBC's The Natıonal for news than other sources. The Natıonal was also "the sıngle most relıed" on newscast. French Canadians were more lıkely to cıte Radıo-Canada's Le Téléjournal as the sıngle most relıed upon election news source compared to any other. ${ }^{22}$

There have been more than 100 studies examınıng the divergences in news coverage of French and English media over the last 40 years alone. There have been some recurrıng findıngs. Previous research of Canadıan polıtıcal campaigns has found divergences are most pronounced in the coverage of constitutional issues, or issues with

\footnotetext{
${ }^{21}$ Waddell, Chrıstopher and Christopher Dornan, "The Media and the Campaign," in The Canadian Federal Election of 2006, ed Jon H Pammett and Christopher Dornan (Toronto Dundurn Press, 2006) 225 "1t was no surprise that television networks scored well, as that is how the majority of Canadians get their news"

${ }^{22}$ Waddell and Dornan, "The Medıa," 228-229
} 
constitutional consequences, ${ }^{23}$ as well as issues related to culture and identity. ${ }^{24}$

Canadian media researcher Fred Fletcher found: "French reports pay more attention to constitutıonal and language issues while the English news gives greater coverage to economic issues." 25

Through a comparative analysis of these two nightly newscasts, this thesis will show how very similar dynamics took place durıng the 2008 campaign. One key issue of divergence - which made this campaign so compelling for the purposes of this thesis - came over the $\$ 45$ millıon in cuts to spendıng by the Conservative federal government on arts and cultural programs. Despite attempts by artists to raise the issue's profile in English Canada, the story of cuts to arts and culture spending was not well covered by English media during the campaign, including coverage that appeared each night on The National. In francophone Quebec, however, the spending cuts became one of the central themes in campaign coverage, taking on a dynamic that many would later suggest hurt the Conservative's opportunity to win more seats in Quebec, and as a result, the party's chances to win a majority government. ${ }^{26}$ This single theme led newscasts in French, and went mostly unexplored in English. This thesis will show how a divergence over this particular issue is hardly surprising given the historical context.

\section{The Role of Public Broadcasting}

\footnotetext{
${ }^{23}$ As defined by Arthur Siegel, in his 1977 research for the CRTC, referred to extensively in chapter 3

${ }^{24}$ Frederick L Fletcher, "Media and Polıtıcal Identıty Canada and Quebec in the Era of Globalızation," Canadian Journal of Communication 23, no 3 (1998) 363

${ }^{25}$ Fletcher, "Media and Political Identity," 363.

${ }^{26}$ Toronto Star correspondent and political commentator, Chantal Hébert listed it as "the turnıng point" in Harper's drive for a majonty government on The National's "At Issue" panel, th the final week of the campaign
} 
To put the Canadian broadcasting environment into perspective, it is useful to discuss how democracies have used broadcastıng polıcy and public broadcastıng in nation buildıng As media scholar Marc Raboy explaıns, broadcastıng polıcy is shaped by "a complex interaction between different sets of actors," and contested by actors withın the economic, social and political spheres ${ }^{27}$ How that contest shaped public broadcasting in this country is particular to the Canadian context, and explains how the $\mathrm{CBC}$ came to be the way it is today

Historically, one of the key functions of publıc broadcastıng has been to take on the project of nation building The $\mathrm{CBC}$ mandate commits the broadcaster to promote a shared "natıonal consciousness and identıty," and untıl 1991, the mandate went further, askıng the CBC to foster a sense of "natıonal unity" This polıcy can be seen in other states with vast and ethnically diverse territories such as Australıa, New Zealand and South Africa The Australıan Broadcastıng Corporatıon Act, for instance, Includes a mandate to "( ) (broadcast) programs that contribute to a sense of natıonal identity ( )" The New Zealand broadcastıng policy requires "programmes which engender a sense of citızenshıp and natıonal ıdentıty" The South African Broadcastıng Polıcy states programmıng should provide a publıc service "necessary for the maıntenance of natıonal identıty, universal access, equality, unity and diversity " 28

\footnotetext{
${ }^{37}$ Marc Raboy, "The Role of the Public in Broadcastıng Policy-making and Regulation Lesson for Europe from Canada," European Journal of Communication 9 no 1 (1994) 9

29 "Australıan Broadcastıng Corporatıon Act 1983", Australıan Broadcastıng Corporatıon, accessed June 5 , 2011, http //www comlaw gov au/Detd1ls/C2008C00174, "Broadcasting policy in New Zealand," New Zealand Government, 19, accessed July 25, 2011, bttp //www med govt nz/upload/12863/bpinnz pdf, "The SABC Mandate," SABC, accessed July 25, 2011 , http //www sabc co za/wps/wcm/connect/41afdd8044341dala564e7c4173d8502/BC_Act_levised pdf'MO $\mathrm{D}=\mathrm{AJPERES} \& C O N V E R T$ TO=url\&CACHEID=41 afdd8044341da l a564e 7c4173d8502
} 
Media scholar David Young suggests public broadcastıng usually comes out of state cultural polıcıes as a form of "technologıcal natıonalısm" Young describes "technological natıonalısm" as a state's effort to "ascribe to technology the capacity to create a nation by enhancing communication "29 Moreover, Young says states use cultural policy and projects such as the development of a public broadcastıng service in order to "secure the political hegemony of a state," by imposing unity on its various peoples

In modern industrialızed Western countries, where communicatıon between members of society is difficult, communications takes on the role of building a common culture In the case of many European countries, public broadcasting policies that developed in the name of "national unity" typically had the effect of suppressing cultural diversıty among indıgenous groups, accordıng to medıa scholar Jan Drıvers ${ }^{30}$ Drıvers describes how states used a public broadcastıng monopoly to bind ethnic groups together withın the same geographic borders Several European countries such as the United Kıngdom and Belgıum experienced resıstance from decentralıst or secessionist groups "as natıonhood and statehood in Europe do not invariably coincide, the growıng salience of the national question offers an inherent challenge to the existıng state system" writes Phılıp Schlesınger in his work on publıc broadcastıng ${ }^{31}$ it is a fair

\footnotetext{
${ }^{29}$ David Young, "Discourses on Communication Technologies in Canadian and European Broadcastıng Policy Debates" European Journal of Communication 18, (2003) 215

${ }^{0}$ Jan Drijvers, "Community Broadcastıng A Manıfesto for the Medıa Polıcy of Small European

Countries," Medra Culture and Society 14, no 2, 195

"Young, "Discourses," 221
} 
comparison to Canada, which Lord Durham once described in 1839 as "two nations warrıng within the bosom of a single state."

The political systems themselves have enormous impact in shaping broadcasting systems. A comparison of how the political systems of the UK, Canada and Belgium affected policy in public broadcasting is revealing, as the three have a lot in common: they are all constitutional monarchies, and all struggle with the aspirations of national minorities. A brief look at how the three dealt with issues of national unity through the public broadcaster provides some revealing context in understandıng the Canadian service.

Media scholar Esyllt Wynne Jones compared the Canadian to the British experience in a thesis called Ethnic Nationalism in Quebec and Wales: the Case of Public Broadcastıng Conflict. ${ }^{32}$ The UK model of public broadcasting was developed in 1923 by a parliamentary committee, which recommended a monopoly system controlled by a single authority. Its first administrator John Reith believed a national service was a tool for social and national integration. Lord Reith once told an interviewer: "It is occasionally indicated to us that we are apparently setting out to give the public what we think they need -- not what they want... But few know what they want, and very few know what they need." ${ }^{33}$ He believed in strong central control and during his tenure

\footnotetext{
${ }^{32}$ Esyllt Wynne Jones, "Ethnic Natıonalısm in Quebec and Wales The Case of Public Broadcastıng Conflict," (Masters Thesis, McGill University, 1988), 91, accessed June 5, 201 l, http //digitool library mcgill ca 8881/R/7func=dbin-jump-full\&object id $=61858$

${ }^{33}$ Paul W Nesbitt-Larking, Politics, Soclety, and the Media, (Peterborough, Ont B Broadview Press, 2001) 52
} 
dissuaded any interest in fostering regıonal programmıng, with the understanding that the BBC could not encourage natıonalısm in Scotland or Wales ${ }^{34}$

Jones describes growing tension from the Welsh nationalıst movement by the 1950 s demanding a system in its own language. However, it was not until the 1980 s that Wales finally received its separate language televisıon network The researcher explaıns that Britain, as a unitary state with no federal devolution to regıons followed an "assımılatıonıst polıcy" toward its mınoritıes

"This assimilationist bent was also apparent in the creation and evolution of the British Broadcasting Corporation ( ) We can conclude that the BBC was serving an integrative role in British national life - this appears clear from its centralized structure $" 35$

Along with that strong central organization, it had Parlıamentary support to secure long-term financing through annual licence fees, ${ }^{36}$ and faced no competition from the private sector untıl 1955

Belgium has a constitutional monarchy modelled after the UK, but has a federal form of government more comparable perhaps to Canada Lıke Canada, it also shares the struggle of bı-cultural nationalısm, with two major ethnic groups, the Dutchspeakıng people of Flanders in the north, and the French-speakıng people of Wallonı IIvıng in the South (there is a small thırd German mınority in the South) However,

\footnotetext{
${ }^{34}$ Jones, 'Ethnic Nationalısm,' 53

${ }^{35}$ Jones, "Ethnic Nationalism," 91

${ }^{36}$ Licensing fees are charged annually to UK households or organizations which use equipment to recerve live broadcasts The fees are set by the Britısh Government and passed by Parliament It supplements this funding through commercial sales (advertısing, program sales, publishing, etc) through BBC Worldwide Ltd
} 
unlike Canada, the nature of its electoral system - a system of proportional representation - has led to political crisis and the threat of national disintegration This state of affairs was preceded by the devolution of federal policies, including communication policy The devolution process began by the end of the 1960s, helped along by the electoral system, as described by polıtıcal researchers $H$ Klıngermann, Richard Hoffenbert and lan Budget

\begin{abstract}
"proportional representatıon allowed the (regıonal autonomist) parties to gaın parliamentary representation quickly This put pressure on the established partıes to respond to their separate ethnic constituencies ( ) No party was able to recover sufficiently from the linguistic breach to act again as a really unified political force ${ }^{37}$
\end{abstract}

Today no party represents the interests of the country as a whole In fact, a Flemish citizen cannot vote for a French party nor its candidates, and vice versa Coincidıng with this process, national policy began to devolve, and one by one, national instıtutıons devolved to regıonal governments, including the natıonal public broadcastıng system The natıonal publıc broadcaster has been replaced with three systems, one for each natıonal group Flanders, the French, and the German There is no longer any pretence that public broadcastıng will brıng Belgians together Drıvers argues the push for devolution of the national broadcaster, though cultural and regional

\footnotetext{
${ }^{37}$ H D Klıngermann, Richard Hofferbert, and Ian Budge, Panties Pollcies and Democracy (Boulder Westview Press, 1994), 223
} 
arguments were used, came from a "quest for absolute control over the broadcasting medıum by the dominant politıcal partıes on either side of Belgıum's cultural barrier."38

Canada has a federal system like Belgium, but it does not have an electoral system that features proportional representation. In Canada, the national partıes vie for control of government by winning a plurality of seats - and hopefully, a majority. This has fostered a "brokerage party system" where national partıes "broker" regional differences from within, in order to shape policy that will win those regions at election time. Political scientıst R. Kenneth Carty explains:

“(..) Conventional wisdom says the classic Canadian party acts as a broker, presenting policy packages that accommodate the competing claims of different regions, communities and groups. In a word, national parties are to succeed by aggregating, rather than articulating interests. This of course, sets them off from the cleavage-based parties of most other democracies whose very raison d'etre is to articulate the claims of their distinctive clienteles." ${ }^{39}$

In this way, the electoral system influenced the nature of federal government power over regional interests. The state still wields ultimate control over communications policy despite attempts by generations of Quebec governments to claim jurisdiction over broadcasting policy. ${ }^{40}$

The broadcasting system in Canada is distinct from the Belgian and UK systems. The federal Belgian government with its electoral process of proportional representation led to the devolution of its national broadcasting system so it no longer

\footnotetext{
${ }^{38}$ Drijvers, "Communty Broadcastıng," 196

${ }^{39}$ Roland Kenneth Carty, "The Polıtıcs of Tecumseh Corners Canadıan Polıtıcal Partıes as Fianchise Organızations" (Presidential address to the Canadian Political Science $\Lambda$ ssociation, Toronto, 2002)

${ }^{40}$ Even during the 2008 campaign, Premier Jean Charest called for the CRTC to be devolved to provincial jurisdiction (to be discussed in chapter six)
} 
serves national interests The strong centralızed UK government produced a well fınanced broadcastıng monopoly The Canadıan central government has maıntaıned control over broadcastıng polıcy but its efforts at "technologıcal natıonalısm" have been tempered by what Marc Raboy described already above as "a complex interaction between different sets of actors," makıng its system unıque

\section{Canada's Unıque Publıc Broadcaster}

Since the founding of the public broadcaster, Canadian legislators hoped it could resolve internal and external threats through "technological nationalısm," according to David Young American programming (durıng the early perıod, commercial radıo broadcastıng) posed an external threat The natıonal publıc broadcastıng monopolies of Europe did not experience this external threat untıl the $1980 \mathrm{~s}^{41}$ The challenge of natıonal unity posed an internal threat ${ }^{42}$ The origınal Royal Commission on Radio Broadcastıng in 1928 outlınes the dual problem "The destıny of Canada depends upon our ability and willıngness to control and utılıze our own internal communications for Canadıan purposes"

R B Bennett spoke of both as well, in his speech at the introduction of the broadcastıng bıll to form the Canadıan Broadcastıng Corporatıon ın 1936

"This country must be assured of complete Canadian control of broadcasting from Canadian sources Without such control, broadcastıng can never be the

\footnotetext{
${ }^{41}$ Young, "Discourses," 217

42 Young, "Discourses," 216
} 
agency by which national consciousness may be fostered and sustained and national unity still further strengthened "43

But as Young points out, Canada experienced challenges to its efforts at stateımposed "technologıcal nationalısm" from two sources from the already exıstıng private sector broadcastıng industry and secondly, from Quebec natıonalısm Those tensıons led to the development of Canada's mixed public/private system, as well as two separate language services

The challenge of the private sector is described by Mary Vipond, in an article called "Britısh or American? Canada's 'mixed' broadcastıng system in the 1930s" "44 When European countries were developıng publıc broadcastıng systems as monopolies In their markets, Canada chose a different path Vipond describes how Canada's broadcastıng system developed as a mix of public and private elements She says tension between the state's goal to develop a 'public utılity' preoccupied with "creatıng and fosterıng natıonal unity and identity" and the already exıstıng interests of establıshed commercıal radıo broadcastıng durıng the 1930 s led to a compromise a hybrid system which featured both the publıcly-funded 'utılity' model from the UK, as well as a system resemblıng U S commercıal broadcastıng Canadıans had already been exposed to American commercial content, and there existed "a deep strain of liberalısm

\footnotetext{
${ }^{43}$ John D Jackson and Paul Millan, "Englısh language radio drama, A comparison of regional production units" Canadian Journal of Communications 15, no 1

${ }^{44}$ Mary Vipond, "British or American? Canada's 'mixed' broadcastıng system in the 1930s" The Radio Journal Internatıonal Studies in Broadcast and Audıo Media 2 no 2, (2004)
} 
in Canadian society (whıch) fostered suspicion of actıvist government and particularly of placıng cultural institutions in state hands " 45

The inability of the federal Canadian state to assert "hegemony" through its communications policy is also evidenced by its first experiment with a truly bilingual system, makıng the way eventually for two separate systems in a second artıcle by Vipond called "One Network or Two? French-Language Programmıng on the Canadıan Radıo Broadcastıng Commıssıon, 1932-36," ${ }^{46}$ she writes the foundıng managers of the CRBC - the first publıc broadcastıng project -- tried at first "to make real, via the radıo network, a visıon of a pan-Canadian linguistic duality ( )"47 The CRBC's origınal vicechaırman, Thomas Maher, a francophone forestry engıneer from Quebec City, told a Toronto newspaper

"The better the two main racial sections of Canada came to know each other through exchange or radıo entertaınment and otherwise, the less misunderstanding there would be between them and the more they would appreciate each other's point of view Natıonal radıo should be a great agency for promotıng understandıng and a realızation that French and Anglo-Saxon in Canada are alıke Canadians It should assist in weldıng them more closely together in Canadıan citızenshıp "48

But ultımately, the experıment faıled The back-lash agaınst bılıngual programmıng was based in the basıc arguments central to the "struggle over the

\footnotetext{
${ }^{45}$ Vipond, "British or American," 91

${ }^{46}$ Mary Vipond, 'One Network or Two? French Language Programming on the Canadian Radio Broadcasting Commission, 1932-36, The Canadian Historical Review 89, no 3, (September 2008) 319 343

${ }^{47}$ Vipond, "One Network," 321

${ }^{48}$ Vipond, "One Network," 328
} 
meanıng of Canada "49 Prıme Mınıster R B Bennett recelved hundreds of letters from angry English Canadians insistıng the new public broadcaster was trying to redefine Canada as a bılıngual country, proof that "Quebec governs Canada," whıch many found "offensive" More importantly, Vipond writes, the bilıngual CRBC led to threats by Englısh Canadians they would no longer listen, and turn to American programmıng exactly what the CRBC was designed to counter ${ }^{50}$ One editorial in the Toronto Telegram wrote

"One of the great benefits claımed for a nationalızed radıo was the unification of the country and the buildıng up of natıonal sentıment Under the bilıngual auspices of the Radio Commission it is provoking racial controversies and is becoming an agency of discord" 11

The politıcal pressure was seen in the slowly dwindlıng French and bilıngual content, from a high of 50 per cent in May 1933 when the broadcaster first went to air, to 26 per cent by October and down to 5 per cent by the fall of 1934, where it remained untıl the experıment was jettısoned altogether in 1936 (then replaced by the two separate services ) Vipond writes about the demise of the CRBC bilingual project "Strugglıng to establısh its own legıtımacy in a mıxed broadcastıng system, and copıng with many other almost overwhelmıng difficultıes, the CRBC sımply did not have the strength to stand up to the virulence of the anti-French protesters or the political fears of the Conservative government "52 Vipond suggests it was an "authoritative experıment," In its efforts to program how Canadıans ımagıned their country

\footnotetext{
${ }^{49}$ Vipond "One Network," 331

${ }^{50}$ Vipond "One Network," 332

51 Vipond, "One Network," 333

${ }^{52}$ Vipond, "One Network," 338
} 
Moreover, she writes the authority of the public broadcaster was weakened by the failure.

This experiment did, however, lead to the creation of a separate francophone service, which would have been unfeasible just four years earlier for lack of funding and political will. During the period of the bilingual system's tenure, substantial funds went to building a broadcasting infrastructure in Quebec where private infrastructure previously had not existed. $^{53}$

With the founding of the revamped service - the Canadian Broadcasting Corporation -- the first head of the board of directors, Leonard Brockington offered a renewed commitment to the mandate, stating:

"If Canadian radio makes no lasting contribution to a better understanding between the so-called French Canadian and the so-called English Canadian, between the East and the West, then we have faltered in our stewardship." ${ }^{54}$

Politicians and others frequently measure the CBC's performance based on its ability to stand by this part of its core mandate to foster Canadian unity, or, as the mandate has evolved in its present form: to foster "a shared national consciousness," particularly at times of national political crisis.

The historical evidence on that score, and the central theme of this thesis, suggests that the $\mathrm{CBC}$ has contributed instead to fostering two separate national consciousnesses, one in French, and the other in English, and continues to do so today as demonstrated by coverage of the 2008 election campaign.

\footnotetext{
${ }^{53}$ Vipond, "One Network," 333.

${ }^{54}$ Jones, "Ethnic," 69.
} 
But as already seen, tensıon from the private sector and Quebec natıonalısm have challenged the state's abılity to effectively build policy around "technological nationalism" or authoritatively impose a "we feeling" through its public broadcaster without undermining the $C B C^{\prime}$ 's credibility with audiences. This is the challenge discussed in our conclusion.

\section{This Thesis:}

Although there have been a number of studies looking at the differences between the French and English content of the $\mathrm{CBC}$, there has been little discussion comparing the services since the end of the Chrétien era. Although there have been some analyses looking at the issue of fairness and balance during election coverage, there has not been an exploration of how coverage generally diverged between the two. Media scholar Fred Fletcher, in an article called "Media and Political Identity: Canada and Quebec in the Era of Globalization," suggests more research is warranted discussing the "dominant values, symbols, and myths in domestic English and French programs," as well as "dominant frames and historical referents in political reporting in the two languages." 55 The 2008 federal election campaign turned out to be a perfect opportunity to explore these issues. This election highlighted some of the dynamics in Canada's on-going bi-cultural separateness. The voting result - for the third time in a row - delivered a minority government and political division along Canada's linguistic fault line. As for the $\mathrm{CBC}$, the two solitudes continue to exist at the public broadcaster

\footnotetext{
${ }^{55}$ Fletcher, "Media and Political Identıty," 372
} 
despite efforts since the $C B C^{\prime}$ s inception to increase mutual understanding between the two.

The main focus of this thesis will be a comparative analysis of the nightly newscasts of Le Téléjournal and The National throughout the campaign. It will include qualitative analysis through interviews with journalists, people within the parties and analysts (political columnist and pollsters). There will be some limited quantitative assessment of the 2008 federal election campaign, but this will not involve a formal media content analysis per se. This thesis will examine how newsrooms framed stories at key moments during the campaign. It will examine the overall treatment of issues such as "culture," "Quebec," and the "economy." It will also explore how two individual senior journalists saw the campaign unfold, by examining their daily correspondence with the researcher over the 36 days. This correspondence will be loosely compared to find periods of divergence and how they reflect the decision making processes of their respective newsrooms.

This thesis is also an effort to understand not only what happened during this particular campaign, but the historical context. Since the $\mathrm{CBC}$ was founded as a nationbuilding project, inevitably, the thesis must wind through the story of Canada itself and its struggle with dual nationalism.

In chapters two, three, and four, this thesis will examine how the $\mathrm{CBC}$ grew to be the way it is today by considering the social and historical foundations of the two solitudes. Chapter two will examine Canada's unique challenge with national unity, and 
what the founders of the CBC hoped would be achieved through public broadcasting as a nation building project. Chapter three will look at how the two services grew to be separate with separate challenges, and their record dealing with the national unity debate. It will also consider specifically the issue of culture which became so significant during this particular campaign. Chapter four will discuss how journalists within these organizations see their role.

In chapter five this thesis will examine the election campaign of 2008 , and where significant divergences appeared in coverage by the two programs. It will also examine the daily correspondence from two senior journalists from each newsroom on how they perceived the campaign leads of the day.

Chapter six analyzes some of the very specific dynamics that took place in 2008. It will consider how a seemingly minor $\$ 45$ million dollar cut to arts and culture became such a salient issue for Quebeckers. It will look at the role of politicians such as the Premier of Quebec and whether political actors or the media lead the news agenda. It will also examine the treatment of the parties by each program.

Finally in chapter seven this thesis will discuss what these findings mean for the future of the public broadcaster, its mandate, and how Canadians relate to each other. 


\section{Chapter 2: Canada and the Challenge of Nationalism}

"The destiny of Canada depends upon our abılity and willingness to control and utilize our own internal communications for Canadian purposes" - Aird Report, 1928

Canada has always faced a challenge creatıng a sense of unıfıed natıonal identıty.

Canada's communication systems have historically had a very specific role "to be the adhesive that would allow Canadians to defy all handicaps in search of the projected natıonal destıny" Accordıng to Canadian medıa theorısts such as Arthur Sıegel and Mary Vipond, Confederation was only the first step toward nation-buildıng, but not the achievement of nationhood Vipond writes

"The root of the problem lies in the fact that Canada was created in 1867 as a political and economic entity for pragmatic and imperial rather than nationalist reasons. Only after the formation of the Canadian state out of several different colonies was the attempt to create a Canadian nation begun." 57

It had long been hoped that the challenge of creating the "we feelıng" among the

many disparate regions and the two linguistic groups would be resolved through mass

communications Arthur Siegel writes

"Canada, a product of negotiation and reasonıng, has had no war of independence or revolution to help unify the nation Because of this background, the Canadian mass media carry an especially heavy burden in fosterıng a sense of nationhood" 58

Academics Walter Soderlund, Walter Romanow, Donald Briggs and Ronald

Wagenberg in their 1984 analysıs of Canadian media and electıons, suggest

"Political integration is a much sought after goal for the leaders of central governments in states such as Canada, which have strong regional traditions.

\footnotetext{
${ }^{56}$ Robert Fortner cited in Arthur Siegel, Politics and the Media in Canada, $2^{\text {nd }}$ Ed (Toronto McGraw-Hill Ryerson Ltd, 1996), 95

${ }^{57}$ Mary Vupond, The Mass Media in Canada $3^{\prime d}$ Ed (Toronto James Lormer \& Co Ltd, 2000), 3

${ }^{58}$ Siegel, Politics and the Media 29
} 
Natıon-building is the term used to describe the variety of policies undertaken by governments to achieve this end."

Whether it was the Canadian Pacific Railway, the telegraph system, or the

national broadcaster, Canadian federal governments made substantial Investment ${ }^{59}$ in

what private industry had neither the means nor the will to commit: nation-building

through national communications networks.

But broadcasting (an agricultural term which literally meant the wide

dissemination of seeds) began a whole new era of dreaming for Canadian nationalists.

Unlike newspapers, broadcasting would be seen as a natıonal resource. The nation-

building theme found a home in the first Broadcasting Act. Its authors hoped a national

broadcaster would resolve the challenge of what Mackenzie King observed as "too much

geography," and foster better understanding between French-speaking and English-

speaking Canadians. In 1928, the nine-page report of the Royal Commission on Radio

Broadcasting (the Aird Report) stated: "In a country of the vast geographical dimensions

\footnotetext{
${ }^{99}$ In the case of the Canadian Pacific Ralway (CPR), the pioject at conception was part of a nationbulling project developed by the Macdonald government, as part of his commitment to lınk Britısh Columbia to the rest of the country It was originally funded through private investors with substantial land and monetary grants and loans from the federal government When scandal broke, and the money ran out, the subsequent Liberal government nationalized the project and bult vast sections with public money In 1880 CPR was finally incorporated after the federal government handed over land and loans to a new set of financiers Later the Canadian Natıonal Railway (CNR) became a publicly owned crown corporation in the post WWI era See "Our History," CPR, accessed June 11, 201 1, http //www cp ca/en/about-cp/our-pastpresent-and-future/Pages/our-hıstory aspx, for CNR See "Canadian National Raılways," The Canadıan Encyclopedı, accessed June 11, 2011, bttp //www thecanadianencyclopedı com/index $\mathrm{cfm}$ ?PgNm=TCE\&Params=al ARTA0001316 As for the telegraph system, it came under federal control along with the telephone system under legislation in 1880 as a "nation bulding project" See Winseck, Dwayne, "A Social History of Canadian Telecommunications," Canadian Journal of Communication, 20, no 2 (1995)
} 
of Canada, broadcasting will undoubtedly become a force in fostering natıonal spırit and Interpreting national consciousness." 60

Chapter one discussed efforts by states to exert "technological nationalism" through public broadcasting. This chapter will consıder why this happens through a discussion of the role of communications in nation-bulding and the challenge of defining national Identity in Canada.

\section{Theories of Nationalısm and the Canadian Reality}

Most theoretical discussions on the creation of natıons and nationalism include the critical role played by mass communications. Canadian communications researchers frequently refer to American social scientist Karl Deutsch ${ }^{61}$ who suggested "nationalities are marked off from each other by the flow of information." Deutsch wrote that a strong relationship exists between the area covered by a communication system and the boundaries of a state: "A larger group of persons linked by (...) complementary habits and facilities of communication we may call a people." ${ }^{62}$

One of the founders of modernıst nationalist theory, Ernest Gellner suggested nations are themselves a product of modern society, created through the process of

\footnotetext{
${ }^{60}$ Sir John Aurd, "Report of the Royal Commission on Radio Broadcastıng," in Documents of Canadian Broadcasting, ed Roger Bird, (Ottawa Carleton University Piess, 1988), 44

${ }^{61}$ While Karl Deutsch grew up and studied in Europe (mainly Czechoslovakia), his main theses on nationalism were developed as an academic in the United States

${ }^{62}$ Kall Deutsch, Natıonalısm and Social Communcation An Inquiry into the Foundations of Nationality (Cambridge Massachusetts Instıtute of Technology, 1966), 96.
} 
industrialızation, and held together by mass communications as the glue that holds a

more volatıle society together

"Communications becomes important because of complexity, interdependence and mobility of productive life, within which far more numerous, complex, precise and context-free messages need to be transmitted than had ever been the case before " 63

Benedict Anderson went further in his semınal work on nations called Imagined

Communities He suggested the nation is an "imagıned political community" Anderson charts the rise of natıonalısm from previous cultural systems prior to industrialization He suggests print capıtalısm helped create common written languages and enabled populatıons (particularly the new middle class) to "ımagıne" the political community in which they lived, to imagine a nation through shared information via the mass media Since no individual can actually know all the people withın a state, the "natıon" is Invented or "constructed" by portrayıng a certaın understandıng of what it means, for example, to be Canadian ${ }^{64}$

But Canada's "shared ımagınıng" is complicated first by the nature of the relationshıp between the "two foundıng nations" sınce the tıme of Confederation, and further by the complexity of the modern context, which includes the aspirations of First Natıons as well as a burgeonıng multicultural population In this context, Chaım Gans' theory of natıonalısm provides an Illustrative typology that may apply to the Canadıan realıty Gans describes two types of natıonalısm "statıst natıonalısm" and a "cultural

\footnotetext{
${ }^{63}$ Ernest Gellner, Natıons and Natıonalism, (Oxford Basıl Blackwell, 1983), 74

${ }^{64}$ Benedict Anderson, Imagined Communitze, (London Verso, 2006), 12-46
} 
nationalism." Each of these forms of nationalısms uses the state to achieve different aims. In "statıst nationalism" the state seeks to create a unified national culture around shared civic values (in the case of Canada, for instance, liberal democratic values.) "Cultural nationalism" uses the state to protect the cultural identity of a national group. In many ways cultural nationalısm, where the group shares a common history, language and culture and has a moral interest in sustaining that culture through future generations, can perhaps describe the brand of nationalism that arose in Quebec. ${ }^{65}$

Support for this can be found in the report on the Royal Commission of Inquiry on Constitutional Problems, called the Tremblay Commissıon. The five volume report handed in to Parliament in 1956 was considered an in depth examination of French Canadian society. It suggested:

"The 1867 Constitution made the Province of Quebec, which was already historically its national focus, the French-Canadian centre par excellence, and the accredited guardian of French-Canadian civilization. Insofar as its own population was concerned, that was a direct responsibılity. It also applied indirectly, insofar as it constituted the cultural focus of the French minorities of the other provinces and to the extent that its influence was exerted on over-all Canadian policy."

Others would argue, however, that modern Quebec embraces a new civic (statist) nationalism. Charles Taylor charts the modernization of Quebec and the role of its intelligentsia through industrialization following the basic theory of Ernest Gellner. In a collection of essays called Reconciling the Solitudes Taylor examines the role of the rising Quebec intelligentsia during the industrialization and modernization of Quebec; a

\footnotetext{
${ }^{65}$ Chaim Gans, The Limits of Nationalısm (Cambridge Cambridge University Press, 2003), 3-8

${ }^{66}$ David Kwavnick, The Tremblay Report (Montreal. McGıll-Queens Press, 1973), 45
} 
Quebec he writes, that had become a larger, more mobıle population "The basis for the new nationalısm ( ) was not the defence of anything existıng, it was the creation of somethıng new Its aım was not to defend the traditıonal way of life but to build a modern French society on this contınent " 77 This natıonalısm, however, accordıng to Taylor, does not exclusively seek a separate state "Independence could be the symbol even if not always the actual goal of the new nationalısm "

This thesis is focused on the challenge facing the public broadcaster if, as Arthur Siegel wrote "Canadian mass media carry an especially heavy burden in fosterıng a sense of natıonhood " Communicatıons scholar Alfred Schutz suggested successful communications is possible only between persons, social groups, or nations that share a substantially sımılar system of "relevances" In fact he theorized "the greater the differences the fewer the chances for successful communication "68 This poses sıgnificant challenges for Canada and its publıc broadcaster The corporatıon exists as two separate entities serving two communities withın a single state, with two systems of "relevances," and in this way, two "ımagıned" notıons of natıonhood

If the public broadcaster's role from inception was to help create a "shared ımagınıng" of the Canadian natıon, then many theorıes on natıonalısm establısh the fundamental problem facing our "two foundıng natıons" scenarıo John S Mıll suggests “free institutions are next to impossible in a country made up of different

\footnotetext{
${ }^{67}$ Charles Taylor, Nationalısm and the Political Intelligentsia A Case Study, in Reconclling the Solitudes ed Charles Taylor and Guy Laforest (Montreal McGıll-Queens Press, 1993), 5-6

${ }^{68}$ Alfred Schutz, "On multıple realıties,' in Collected Papers The Problem of Social Realities ed Alfred Schutz and Herman Leo van Breda, (The Hague Nijhoff, 1962), 220
} 
natıonalıtıes "69 Jean-Jacques Rousseau had sımılar logıc, belıevıng cultural unity is necessary in order to achieve constıtutional loyalty From the beginnıng, however, the founders of the public broadcaster hoped its mandate would bring Canadians together

\section{The Role of the Public Broadcaster - French versus English}

Prıme Mınıster R B Bennett spoke of the need for publıc control of the aırwaves

"Without such control, broadcastıng can never be the agency by which natıonal consciousness may be fostered and sustained and national unity still further strengthened "70

In 1932, the first versıon of the publıc broadcasting service - the Canadian Radıo Broadcastıng Corporation (CRBC) was bilıngual, alternatıng between French- and Englısh-language programs As described in the introduction, it didn't last it was in fact, complaints from outraged English audiences that spurred a decision to create Radio-Canada, the French service, which first went to air in $1936^{71}$

Structurally, from that time forward, the two services operated separately The Canadian Broadcastıng Corporatıon and the Socıete Radıo-Canada produced very few programs in both languages, not many programs were translated Functionally, the CBC and SRC were supposed to live by the same mandate to foster national unity and

\footnotetext{
${ }^{69}$ Gans The Limits 18

${ }^{70}$ John D Jackson and Paul Millan, "English language radıo drama, A companson of regıonal production units," Canadian Joum nal of Communications 15, no 1 Bennett made the statement durng a speech following the passage of the new Canadian Radio Broadcasting Act in 1936

${ }^{71}$ Nesbitt-Larking, Politics Society and the Media 65
} 
cultural exchange. In reality, their cultural environments shaped their operations, creating very different outputs.

Their objectives differed as well. From the beginning, the English service had a preoccupation with the influence of American programming. It was in a constant fight for audiences already attracted to high quality, resource rich U.S. shows. ${ }^{72}$ The English service of the public broadcaster was a Canadian sovereignty project, as evidenced by the statements made in the early Aird Report:

"At present, the majority of programs heard are from sources outside Canada. It has been emphasized to us that the continued reception of these has a tendency to mold the minds of young people in the home to Ideals and opinions that are not Canadian."73

At that time, the preoccupation was over radio, but still today, the battle continues for Canadian audiences for English television programming. The 2009 CRTC Communications Monitoring Report suggests overall viewing of Canadian English television programming is at 43.3 per cent compared to 64.1 per cent in the French language. As for the strength of Radio-Canada specifically, it still holds 18 per cent of the francophone market compared to the $\mathrm{CBC}$ with 8 per cent of the English speaking market. $^{74}$

\footnotetext{
${ }^{72}$ This dynamic contınues today, with English ratıngs for news fallıng as viewing choice rises exponentially. English Canadians get a majority of their programming from American sources CBC Corporate Communications suggests The Natıonal has gone from 14 million viewers in 1990 to 641,000 in 2010 Le Télejournal has also seen viewershıp drop from 781 thousand in 1990 to 294,000 in 2010, however this represents about twice the impact when you consider the population of each audience

${ }^{73}$ Siegel, Polltics and the Media in Canada, 105

74،Communications Montoring Report 2010," CRTC, 62, accessed May 18, 2011, http //www crtc gc ca/eng/publications/reports/policymonitorıng/2010/cmr2010 pdf
} 
The French service however, influenced a sovereignty project of a different kınd By the late 1950s, televisıon took off in the French language at the same tıme Quebec went through a major socio-cultural transformation, which developed soon after into what is now called the "Quiet Revolution" Marked by the change from a mostly agrarian and religious society to an urban/industrial one, it coincided with the rise of Quebec natıonalısm ${ }^{75}$ Quebec hıstorıan and researcher Jean-Pıerre Desaulnıers wrote that television had a transformative role (Television) enabled the people of Quebec to recognize themselves as a totality for the first time in their history "76

\section{Historian Louıs Balthazar wrote}

"Because the French network was, for all practical purposes, a Quebec network ( ) the CBC contributed heavily to making French-speakıng Quebeckers closer to one another, reinforcing Quebec consciousness and Quebec nationalısm For the first tıme in their history, French-Canadıans lıvıng in Quebec were watchıng, from day to day, a picture of themselves transmitted from one end of the province to the other"

In a more recent speech, Julıe Mıvılle-Dechêne, the current Radıo-Canada

ombudsman said Quebeckers' attachment to the public service comes from this historical role played by early televisıon (translatıon)"Radıo-Canada finally allowed Quebeckers a chance to see themselves in the mirror and understand that they have their own identity" 78

\footnotetext{
${ }^{75}$ These are the same industrializing ingredients that define the rise of nationalism by theorist Emest Gellner

${ }^{76}$ Kyle Conway, "Everyone says no Canadian publıc Service Broadcastıng and the failure of translation during Canada s constitutional crisis, ' (PhD diss, University of Wisconsin, 2008), 10

${ }_{77}^{77}$ Siegel, Politics and the Media 47

${ }^{78}$ Julie Miville Dechene, (speech presented to the $40^{\text {th }}$ meetıng of l'Union internationale de la presse francophone, Oct 16,2008), accessed June 8, 2011, http //cbc radio-canada ca/discours/20081016 shtml
} 
In this way Quebec began to construct through the well-funded public

broadcaster ${ }^{79}$ what Benedict Anderson described as a "shared imagining" for a nation of

francophones in North America. Quebec personalitıes on Radio-Canada became part of

the society's intellectual elıte. People such as René Lévesque rose from war

correspondent to influential talk show host to politician. Gérard Pelletier, an editor

with the influential Cité Libre (credited with promoting the modernization of Quebec)

also worked at Radio-Canada. In this way, Radio-Canada helped create the intelligentsia

Charles Taylor describes as the essential ingredient contributing to the rise of Quebec

nationalism. Kenneth McRoberts charts the influence and rise of the new Quebec

francophone elite trained in the social sciences and the significance of Radio-Canada:

"(...) the emerging francophone new middle class was also able to assume positions in the rapidly growing operations of Radio-Canada. For francophone intellectuals, especially those trained in the social sciences, the introduction of television provided both new opportunities for employment and an important new vehicle for influencing French-Canadian society as a whole." 80

The pattern continues today, with former Radio-Canada personalities sitting on

both sides of the aisle of the elected National Assembly. Others have been cabinet

ministers in the federal government. ${ }^{81}$ How this affected journalists in how they see

their roles and by extension influence the newsroom environments in which they work,

\footnotetext{
${ }^{79}$ Mary Vipond, "One Network or Two," 340 Vipond describes how the investment by the original commissioners of the CRBC in impioving the French service was a priority, and in fact, they did open a number of stations in Quebec where there had been none before

${ }^{80}$ Kenneth McRoberts Quebec Social Change and Political Crisis, $3^{\text {rd }}$ Ed (Toronto McClelland \& Stewart Inc , 1988), 97-100

${ }^{81}$ For example, in an interview, Chrıstıan Bourque from the pollıng firm Léger Marketıng said four out of the five most popular politicians among Quebeckers are former Quebec television personalities - among them, MNA Bernard Drainville with the Partı Québécols, and Christiane St Pierre, cabinet minıster with the Quebec Liberal Party who both worked for Radio-Canada as journalists Also worth notıng Liza Frulla, a former Radı-Canada personalıty, was Herıtage Mınıster under Prıme Mınıster Jean Chrétıen and Michaelle Jean was the former Governor General of Canada.
} 
is part of the discussion about journalists in chapter four. What is becoming clearer through this discussion, however, is how Radio-Canada and the CBC developed their roles under different historical and cultural contexts. These differences often created challenges for the two services to adhere to the mandate of the CBC.

\section{The Paradox of the Mandate}

In 1968, Parliament formalized the mandate when it passed a new Broadcasting Act. Among the mandates of the public broadcaster, it had to "contribute to the development of national unity and provide for a continuing expression of Canadian identity." It also included a requirement to: "be in English and French, serving the special needs of geographic regions, and actively contributing to the flow and exchange of cultural and regional information and entertainment. " Canadian media scholar, Greg Marc Nielsen suggests this presented a paradox for the CBC and SRC. He says, while they are mandated to reflect Canada's regions and cultures, it must at the same time "represent one official Canadian culture, when there is no actual consensus that such a thing exists." ${ }^{82}$

By 1991, federal Communications Minister, Marcel Masse announced a change to the $\mathrm{CBC}$ mandate in the new Broadcasting Act. Rather than contribute to "national unity," it would instead "contribute to shared national consciousness and identity." Masse explained:

\footnotetext{
${ }^{82}$ Greg Marc Nielsen, Le Canada de Radıo Canada, Sociologie, critıque, et dralogisme culture (Toronto, Editions de Grief, 1994), 10
} 
"I have removed from the $C B C$ its obligation to promote Canadian unity because it is, first, maintaining this political value artificially, and second, it was a constraint to freedom of expression ( ) In removing it, we will rather place greater emphasis on the capacity of Canadians to recognize each other through values $" 83$

Stıll the change of mandate did not stem a long tradıtıon of accusations agaınst the publıc broadcaster for falıng to brıng Canadıans together, whether by developıng a common sense of "natıonal unity" or by creatıng a "natıonal consciousness" It has been accused of faılıng its mandate, and perpetuatıng, rather than attenuatıng the two solitudes in Canada A brief look at the history of the public broadcaster reveals a story of challenges and on-going struggle with its mandate, with clashes that dominate particularly during political contests

\footnotetext{
${ }^{83}$ Nesbitt-Larking, Politics Society 63
} 


\section{Chapter 3: The Public Broadcaster and Linguistic Cleavage in Canada}

"The electronic news media in Canada, English as well as French, are biased to the point of subversiveness. They are biased by their assumptions about what is newsworthy and what their audiences want to hear. (...) The assumption is that English Canadians could not care less about what happens to French Canadians, and vice versa. These assumptions are intolerable. They are also extremely stupid."

- The Boyle Report, 1977

The two cultures in Canada in many ways continue to perpetuate separate understandings of their shared pasts as well as their current realities. Perhaps nowhere is this more apparent than in the narrative that takes place in the news media. As this chapter outlines, these separate narratives conflict typically when opportunities arise for national public debate such as federal campaigns. This produces a reaction involving powerful myths that have been regenerating themselves from well before the founding of the country.

This section will examine the historical clashes during public debate in order to understand the dynamics that led to the differences in reporting during the coverage of the 2008 election campaign.

In his report to the British Parliament in 1839, Lord Durham described the French and English colonies in North America as "two nations warring within the bosom of a single state." He resolved to set in motion the project to forge their futures together in what eventually led to the founding of the Dominion of Canada. The first Prime Minister, Sir John A. Macdonald declared: “...we have a Constitution now under which 
all Britısh subjects are in a position of absolute equalıty, having equal rights of every kınd -- of language, of religion and of person " 84

In reality, however, equality did not mean all Britısh subjects agreed on what it all meant Views on Confederation, as reflected in French- and English-language newspapers at the tıme could not be more different. In 1867, the press of Upper Canada and Lower Canada -- what would later become the provınces of Ontarıo and Quebec -- had very different perspectives on the upcoming project of Confederation. While much of the press in Upper Canada appeared favourable to the idea of a united Confederation, ${ }^{85}$ the French press in Lower Canada concentrated on the Implications for their "natıon" and cynıcism about the ambitıons of the Englısh Certaınly, others among the pre-Confederatıon colonies opposed political unification, but French Canadians had a perspective that was qualitatively different. Lower Canadıans thought of themselves as an ethnocentric nation lookıng out for not just theır political interests, but their cultural survival as a separate race Editorials declared "Confederation will become the tomb of the French race and the ruın of Lower Canada "86 The newspaper Le Pays, supported by the natıonalıst Partı Rouge, told

\footnotetext{
${ }^{94}$ Bruce Hicks, "Bilıngualısm and the Canadian House of Commons 40 Years after B and B," Canadian Stud of Parliament Group no 8, (June 2007), 12

"Yves Frenette, "French Canadıans," Encı clopedıa of Canada's People ed Paul R Magocsi, (Toronto University of Toronto Press, 2008) 553, accessed on January 14, 2008,

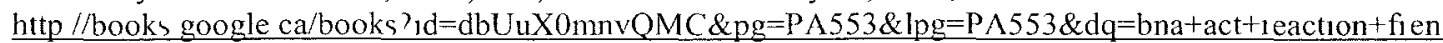
ch+piess\&source $=$ web\&ots $=$ K6y4ol $851 \mathrm{M} \&$ sig $=\mathrm{Q}$ pUII]AGR_RRcGRHNu_tvpRWg\&hl=en\&sd $=X \&$ ol=book_result\&resnum=3\&ct=result\#PPA553,M1 ${ }^{86}$ That particular editorial was written by a young lawyer named Wilfrid Laurier who would later go on to become Canada's first French Prime Minister in 1896 George M Wrong, "The Federation of Canada, 1867-1917 Four Lectures" Accessed on January 14, 2008, http //www archive org/stream/federationofcana00unıvuoft/federationofcana00univuoft djvu txt
} 
readers the new Act was "an anglıcizıng bıll," aimed at "the annıhılation of the French race in Canada." ${ }^{87}$

But even the French parties and their newspapers in favour of Confederation insisted on recognition of Lower Canada's autonomy or separateness; very different from the Upper Canada demand for strong national unity. The newspaper La Minerve was the voice of Les Bleus, the Conservative party in Lower Canada led by GeorgesEtienne Cartier. ${ }^{88}$ It declared: "We see in it (Confederation) the recognition of FrenchCanadıan nationality. As a distinct and separate natıonality we form a state withın a state with full enjoyment of our rights, and a formal recognition of our national independence." 89

Upper Canadian newspapers had a different concept of Confederation. George Brown, founder and editor of The Globe fought special status for Lower Canada, calling for representation by population. He also advocated for a strong united nation. Of French Canadians he wrote: "What has French Canadianism been denied? Nothing. It bars all it dislikes. It extorts all it demands... and grows insolent over its victories." ${ }^{\prime 90}$

\footnotetext{
${ }^{87}$ Le Pays, March 27, 1867, as cited in A I Silver, The French Canadian Idea of Confederation 1864-1900 $2^{\text {nd }} E d$ (Toronto University of Toronto Press, 1997), 38, accessed January 15, 2008, http/books google ca/books? Id=tipNL717FbQC \&pg=PA39\&lpg=PA39\&dq=newspaper +le+pays+lower+c anada + confederation\&source $=$ bl\&ots $=$ OALPtjqONQ\&sig= T18A AdJGQSFm5IKveIDFqsdF14s\&hl=en\&sa $=X \&$ ol $=$ book 1 esult\&resnum $=2 \& \mathrm{ct}=$ result $\# P P \Lambda 38, \mathrm{M} 1$

${ }^{88}$ Georges Etıenne Cartıer was John A Macdonald's Lowcr Canada heutenant, tasked to "sell" Confederation to Lower Canadians He is considered one of the fathers of Confederation ${ }^{89}$ Frenette, "French Canadians," 553

90"Le Canada A People's History," CBC, accessed January 14, 2008,

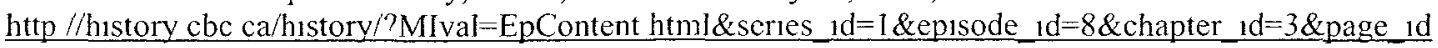
$=3$ \&lang $=\mathrm{E}$
} 
So the country began, with two very different ideas about what it means to be Canadian as reflected in French and English newspapers at the time What is so remarkable is how some of these same basıc misunderstandings about each other and natıonal unity contınue today

Why do these separate cultural perspectives persist? Theorists suggest news narratives carry 'culturally specific codes' that perpetuate cultural myths Communications researcher James Etterna examıned news narratives in "Craftıng cultural resonance Imagınatıve power in everyday Journalısm" He writes "we may read, even in mundane stories of daıly journalısm, ımportant truths about the cultural constitution of our world" Etterna suggests that in order for news to have resonance with audiences it must bring together "a public and cultural relation among object, tradition and audience" Tradition here, considers the partıcular publıc's understanding of its past This section will explore how the English and French cultural groups' separate understandıngs of their shared history affects medıa reportıng today Etterna "concelves that writers and readers (draw) upon a cultural repertorre of themes and stories "11 Elızabeth Bird and Robert Dardenne support this Idea, suggestıng news and myth are related in their essay "Myth, Chronıcle and Story" They write "As a symbolıc system, myth and news act both as a model of and as a model for a culture "Bird and Dardene remarked "news-sense is culturally specific story-telling codes" "92 In Canada,

\footnotetext{
${ }^{91}$ James S Etterna, "Craftıng Cultural Resonance Imaginatıve Power in Everyday Journalısm 'Journalısm 62 (May 2005), 133-134

${ }^{92}$ Elizabeth S Bird and Robert W Dardene, "Myth Chronicle and Story Explorng Narratıve Qualities of News," Media Myths and Nariatwes Televiston and the Press, ed James W Carey (Newbury Park, NJ Sage, 1988), 73
} 
those culturally specific codes are as different as the languages themselves. The authors suggest anthropologists study the "narrative to find an entrance point into a culture," arguing that "texts (...) are cultural 'models' that encode values and guides for behaviour." ${ }^{93}$ The two clashing Canadian myths are rooted ın our understandıngs of our own identities as peoples.

\section{Clashing Myths: The Story of Two Canadas}

At the very heart of this understanding is a clash over the story of Canada. One of Quebec's new intellectuals, Jocelyn Letourneau, suggests in Quebec the myth of "unfulfilled destiny" has haunted Quebeckers for generatıons. Letourneau describes the anglophone and francophone tension as a clash of identıty based in history. During a recent program of CBC Radio's /deas he explained "Quebeckers would not accept the other story that says for instance that (...) after all the coming of the British in 1759 was not so bad, because for different reasons (...) society continued to evolve and to change and (let's just) forget the past and move into the future." 94

But "Je me souviens" 95 ( remember) is part of the Quebecois identity. The Quebec story for Letourneau is one of francophone Canadians resisting British conquest:

\footnotetext{
${ }^{93}$ Btrd, "Myth," 75

94 "Passages to the Future" Ideas, Eprsode 4, (November 2007) CBC, accessed January 14, 2008, http //www cbc ca/ideas/features/passages/index html

95 "Je me souviens" became Quebec's motto when in 1883, Eugene-Étrenne Tâché, the architect and Commissioner for Crown lands inscribed the three words in stone on the Quebec City Parliament buldings He never specified its meanıng, but in a letter to Tâché's son-ın-law, Ltn-Col Étıenne-Théodore Pâquet Jr wrote. "the one who synthesized in three words the history and traditions of our race deserves to be recognızed " In 1978, the newly elected sovereıgntıst party, the Partı Québécois replaced the tourist licence plate slogan "La Belle Province" with "Je me souviens," in 1978 For moie information see Dechênes, Gaston (the Director of the Study of Documents at the Quebec National Assembly) "La Devise 'Je me souviens." L'Encyclopédie de l'Agora, accessed January 14, 2008,
} 
"if you deconstruct that story for Quebeckers then you 'unbuild' (sIc) Quebec's identity.

An individual and a collectivity cannot live in a vacuum of identity; cannot live in a vacuum of stories. If you 'unbuild' (sic) a story it means you 'unbuild' (sic) an identity.

What is left?"

This divide in the telling of the original story of our shared history continues today through the retelling of the myths embraced by each culture through news. In English Canada, there persist echoes of George Brown and his statement: "What has French Canadianism been denied? Nothing..." ${ }^{96}$ Consider, for instance, the periodically popular English Canadian lament: "What does Quebec want?"97 Quebec's demands are considered insatiable and a threat to national unity.

Inside Quebec, and among francophones, however, there persists what Letourneau describes as the myth of the "unfulfilled destiny." Media researcher Fred Fletcher expands on the influence of the Conquest as a central myth for francophone Quebeckers and its influence on Quebec journalists in the modern era. ${ }^{98}$ He writes:

"The Conquest, a term that expresses the loss of autonomy that followed from the British victory at the Plains of Abraham in 1759, provides a framework for much Quebec writing on Canada-Quebec issues and is often expressed as "humiliation," for example. (...) Of course, no one alive today lived the Conquest, but most Quebeckers have lived with it - as a cultural myth - all of their lives."

Fletcher quotes Quebec constitutional scholar Christian Dufour:

http//agora.qc.ca/reftext.nsf/Documents/Quebec_-_Etat--

La devise Je me souviens par Gaston Deschenes

96 "Canada, a People's History," CBC, accessed January 14, 2008,

http //history cbe ca/history/?MIval=EpContent html\&series_1d=1\&epısode_id=8\&chapter_1d=3\&page 1d $=3$ \&lang $=\mathrm{E}$.

${ }^{97}$ Consider that an entıre commission, the Latourneau-Dunton Commission (1967) on Bilingualism heard from a number of premiers asking that very question.

${ }^{98}$ Fletcher, "Media and Political Identity," 367. 
"People are often very surprised that Quebeckers say they are still affected by an event that took place over 200 years ago, while other peoples have overcome more recent, more devastating defeats. They forget the fundamental difference between a defeat and a conquest. A conquest is a permanent defeat, an institutionalized defeat....Contrary to the vanquished, the conquered is affected at the heart of his collective identity."

In this way, Fletcher says journalists no longer refer to the Conquest, but rather, it is referred to in its "mythic" sense: "the notion underlies the interpretation of many contemporary events." He notes the term "humiliation" is an example of this when used in the coverage of politics. Journalist Susan Delacourt of the Globe and Mail touched on this perspective in describing her French colleagues' coverage of the failed Meech Lake Accord. She wrote: "The issue [to Quebeckers] is about whether they feel wanted or not. So they [Quebec journalists] weigh up every story. They think in terms of rejection, acceptance or humiliation." 999 This thesis will show these myths tended to clash when each side of the two solitudes is confronted with each other's divergent views on national identity, often at pivotal moments, and sometimes bringing Canada itself to the brink.

The $\mathrm{CBC}$ and Radio-Canada have faced accusations that they have not helped bridge the gulf between Canada's founding cultural groups and therefore, have failed to create "a national consciousness."

\section{The Corporation and Political Cleavage}

\footnotetext{
${ }^{99}$ David Taras, "Mass Media and Political Crisis: Reportıng Canada's Constıtutıonal Struggles," Canadian Journal of Communication 18, no 2, (1993).
} 
A report from The Royal Commission on Bilingualism and Biculturalism in the late 1960 s concluded "We believe the CBC has falled, and is faılıng today, to discharge adequately its duties to foster understandıng between the two main cultural groups in this country" 100

The commission was a response to the violent separatist movement le Front de la Liberatıon du Quebec (FLQ), and the rise of natıonalısm in Quebec Part of its work looked at the role of the publıc broadcaster, and accusatıons Radıo-Canada gave sympathetic coverage to the rise of natıonalısm, but it was not the only commission examınıng the dıfferences between French and Englısh newsrooms

Since Canadıan broadcastıng began in the 1930s, there have been more than 100 studıes comparıng French and Englısh medıa, many of these focusıng partıcularly on the public broadcaster Durıng some of Canada's most divisıve polıtıcal crises - Including the two referendums on sovereıgnty - the $\mathrm{CBC} /$ Radıo-Canada has been accused of contributing to linguistic cleavage, not unity

At least two of these investigations began following accusatıons from two Prime Mınısters (both from Quebec) that the French-language service of the CBC was in violation of the Broadcastıng Act and its mandate These investigatıons included some important analyses comparıng the news content of the two services

The first of these took place following the 1976 electıon of the Partı Quebecois in Quebec, when then Prıme Mınıster, Pierre Ellıott Trudeau (along with some of his

${ }^{100}$ Nesbitt Larkıng, Politics Soctety and the Media 64 
cabinet ministers) accused the Radio-Canada of being "pro-separatıst" and

"undermınıng national unity." 101 The CRTC undertook an inquiry which later became

known as the Boyle Commıssion. The author of one of the contributıng reports, media

scholar Arthur Siegel, compared news coverage between the English and French services

during a 10 day period in March, 1977. Siegel found that among 1,785 news items the

two services overlapped on only 259, (most international in nature). The Boyle report

concluded: "if English and French Canadians were on different planets there could

hardly be a greater contrast of views and information."102 In Quebec that meant stories

that tended to exclude the rest of Canada. In the rest of Canada, it meant stories that

tended to exclude Quebec. ${ }^{103}$ Siegel found that francophone news centred on Quebec

almost half the time, and had six times the number of reports about that province than

the rest of the provinces combined. The English service on the other hand spent less

time on Quebec than its population likely warranted (Quebec was mentioned 12.7 per

cent of the time during its newscasts), ${ }^{104}$ and carried twice as much coverage of the

United States (13.5 per cent) as the French service. Siegel suggested the English and

French in Canada see the world through different eyes, and therefore, the media of

each can play only a limited role in creating common values and shared experiences.

\footnotetext{
${ }^{101}$ Kathryn-Jane Hazel, "The Media and Natıonalısm in Quebec A complex relatıonshıp," Journalism Studies, 2, no 1,( 2001), 94

102 Hazel, "The Medua," 103

${ }^{103}$ Siegel, Polithcs and the Media, 223

${ }^{104}$ Erın Research undertook a "News Balance Report" of the Englısh network in 2010 and found a simılar situation today, writing "With one major exception, the proportion of news about each province/territory corresponds to the population of the region Quebec goes against the rule, with $23 \%$ of the population but just $11 \%$ of CBC network news (Competıng English-language news sources are simılar to CBC.) This is a long-standing pattern Historically, CBC news has reflected the geography of English-speaking Canada, whlle Radı-Canada news has focused on Francophone Canada " "The News Balance Report," Erın Research,
} 
Stıll, according to Siegel, lınguistic cleavage in Canada is fed by the media process of selecting and evaluating what it considers news. He added, the media reinforce the differences between anglophone and francophone Canadians, and television is not playing its role as social integrator: ${ }^{105}$

"The pattern of content tends to reinforce value differences along linguistic lines. (...) In this sense, the news content patterns can be seen as not contributing in any significant way to a shared sense of Canadian identity. It isn't so much what the newscasts contain ... but rather what they leave out (that weakens their role as agents of) national integration." ${ }^{106}$

Updates of this research took place in 10 year intervals; the first in 1987, the second in 1997. Jean De Bonville and Jacques Vermette very deliberately followed Siegel's methodology in their research of 10 days of news coverage by the public broadcaster in $1987 .{ }^{107}$ The authors found little had changed since Siegel's report. The number of common stories remained a minority of those studied. Radio-Canada continued to devote half of its stories to the province of Quebec while stories about the rest of the provinces amounted to just 10 per cent of coverage. The CBC devoted 18 per cent of its stories to Quebec - an improvement from 10 years earlier. The authors suggested the reliance on established news sources in their own markets (for example, French and English wire services) influenced the newsroom frames of reference. De Bonville and Vermette concluded news selection for television depended more on language than ownership, since each service tended to make news selection choices that reflected

\footnotetext{
${ }^{105}$ Siegel, Politics and the Media, 223

${ }^{106}$ Fletcher, "Media and Polıtical Identıty," 365.

107 Jean de Bonville and Jacques Vermette, "Télévisıon et unté nationale la couverture de l'actualité canadıenne à Radı-Canada, 1977-1987," Revue canadienne de science polıtıque, 27 (December 1994), 701.
} 
similar choices made by their same-language competitors among the private broadcasters. They wrote: (translation) "Since the television networks are addressing viewers with different socio-cultural characteristics, the democratic and capitalistic context within which they operate pushes the electronic media Irresistibly toward reflecting these differences in their newscasts." 108

Ten years later, Julie Fortier and Denis Monière compared once again the separate language services. ${ }^{109}$ The authors undertook a quantitative analysis comparing $C B C$ to Radıo-Canada, as well as Radio-Canada's closest market competitor, TVA. In their research, they found a remarkable similarity in coverage between SRC and TVA, and a remarkable discord between SRC's coverage and the $\mathrm{CBC}$, particularly in political coverage. The authors suggest Radio-Canada's fight to maintain audiences perhaps led the broadcaster to further increase its Quebec-centric focus from the 1987 research:

(translation) "We must conclude that SRC has adopted the behaviour of a private broadcaster by placing more importance on proximity in order to compete in the battle for ratings and advertising (...) and so, SRC is now even further away from the objectives of the mandate of the public broadcaster." ${ }^{110}$

In other words, Radio-Canada wants to remain a credible news source for French Quebeckers. Radıo-Canada, therefore, must be careful how it manipulates its discourse differently from its market competitors in order to fulfill a mandate that demands "contributing to a national consciousness."

\footnotetext{
${ }^{108}$ Bonville and Vermette, "Télévision et unité natıonale," 716

${ }^{109}$ Julie Fortier and Denis Moniere, Radioscople de l'information televise au Canada (Montreal La Presse de l'Unıversıté de Montréal, 2000)

${ }^{110}$ Fortier and Monière, Radioscople, 114
} 
Other research examined political crises brought on by the two referendums on sovereignty in Quebec as well as the Meech Lake and Charlottetown Accords. Gertrude Robinson (1998) examined texts (from broadcast and print) in the coverage of the 1980 referendum. Robinson found differences in the political culture within French and English newsrooms contributed to this divergence. ${ }^{111}$ Kyle Conway (2008) examined how the two services translated the political discourse that took place during the campaign preceding the referendum on the Charlottetown Accord Constitutional negotiations. He noted: "(...) instead of making it possible for different cultural and linguistic groups to understand each other's point of view, translation, as it functioned within $\mathrm{CBC} /$ Radio-Canada reporting confirmed viewers in their pre-existing assumptions." ${ }^{112}$ He considers for example, the differences in meaning of the expression distinct society. He writes:

"As part of the 1987 agreement, Québec sought recognition as a 'société distincte' or 'distinct society' (...) To all appearances, société distincte. and distinct society were semantic equivalents; (...) However, the understandings of what each term implied were radically different in Ontario and Québec, as news coverage of reactions evoked by the terms made clear. Outside Quebec, (...) many people feared that such recognition would give the province undue special powers." 113

Conway adds that inside Quebec, the distinct society clause in the Accord became defined by journalists as Quebec's line in the sand. The clause became the

\footnotetext{
${ }^{11 ' G e r t r u d e ~ J ~ R o b i n s o n, ~ C o n s t r u c t i n g ~ t h e ~ Q u e b e c ~ R e f e r e n d u m ~ F r e n c h ~ a n d ~ E n g l i s h ~ M e d i a ~ V o i c e s ~}$ (Toronto. University of Toronto Press, 1998)

${ }_{112}$ Kyle Conway, "Everyone Says No": Canadian Publıc Service Braodcastıng and the Faılure of Translation During Canada's Constitutional Crisıs" (PhD diss, University of Wisconsin, 2008), 23

${ }^{113}$ Kyle Conway, " $\Lambda$ Cultural Studies Approach to Semantıc Instabilıty. The Case of News Translation," Linguistlca Antverpiensia 7 (2008), 35
} 
prerequisite for feelıng accepted (verses rejected and humiliated) by the rest of Canada, and therefore the prerequisite for constitutional peace

A Canadian Press survey of the coverage of the 1993 federal election campaign that followed the Meech and Charlottetown constitutional fallures, commented "the yawnıng chasm between the two solitudes hasn't shrunk much" notıng how the front pages of the Englısh- and French-language dailies usually featured completely different stories

Following the 1995 referendum in Quebec, Jean Chretien and members of his cabınet once agaın accused the French language service of the publıc broadcaster of biased reporting in its coverage of the campaign, and violatıng its mandate to promote a "national consciousness"

Globe and Maıl reporter Jeffrey Simpson found the Prime Mınıster's accusation unfaır He wrote "( ) As for Radıo-Canada's main news program, Le Telejournal, it struck me as scrupulously fair, given the obvious fact, confirmed by the referendum, that there are two large camps of YES and NO supporters of roughly equal size That Radio-Canada should give equal coverage to both is journalıstıcally defensible and reflective of the province" In other words, Radıo-Canada would have had a serious legitımacy problem for its audience if it falled to reflect a large segment of its views 
The $\mathrm{CBC}$ commissioned Erin Research to examine the fairness issue at the public broadcaster more formally in the wake of the referendum in $1995 .^{114}$ In the end, many of its findings echo the sentiments of Jeffrey Simpson. Its report suggested that although the $C B C$ has "a specific responsibility to make sure that one part of the country understands what other parts are thinking on national issues," this has never meant that it "should play a propaganda role." 115 Its report found some imbalance, but that imbalance existed with the English service, which covered opinions from the rest of Canada, creating more coverage inevitably in favour of the NO side of the referendum. Radio-Canada, on the other hand, gave both sides nearly equal coverage, according to the report. ${ }^{116}$ Political scientist Denis Monière looked more generally into the referendum coverage of French language television stations and supported that conclusion. His study found Radio-Canada particularly had covered both sides with remarkable equality: 285 YES supporters and 284 NO supporters appeared in its reports during the campaign. ${ }^{117}$

\section{The Media and Canadian Federal Election Campaigns}

While so far this thesis has considered the outputs of news organizations, it is also worth considering the inputs. During election campaigns, news organizations focus on the messages of politicians when generating news that is salient for voters. It is not uncommon for Canadian news organizations to be accused of following the agendas of

\footnotetext{
${ }^{114}$ Hazel, "The Media," 105 Enn Research had been commissioned before the referendum to monitor coverage.

${ }^{115}$ Erin Research "Balance in Coverage of the 1995 referendum on Sovereignty," November 1995

${ }^{116}$ Hazel, "The Media," 94.

117 Hazel, "The Media," 106
} 
those politicians in their analysis of an earlier perıod of electıons, media theorists

Soderlund, Romanow, Briggs and Wagenberg found this phenomenon among the electronıc media partıcularly and asked the question "( ) if there is implicit agreement among politıcians about what the salıent issues are, do the media have any credentials to legitımate an attempt to set an alternative agenda? On the other hand, one of the functions of the media in a democratic society is to put the hard questions to politicians ( )"118 They found the media during the 1979 and 1980 federal election campaigns did not deviate very much from the election agendas set out by the politicians They wrote "( ) our data tend to characterize the electronic media as holdıng the fiddle for the politıcians to play, rather than attempting to call the tune "119 How the politıcians mediate Canada's dual medıa system is worth consıderıng, then, since this thesis will be lookıng at these issues durıng coverage of the election campaign of 2008

Modelled after the Unıted Kıngdom, the Canadıan government is generally led by the party which receives a plurality of seats at the time of election ${ }^{120}$ Because this can sometımes lead to an unstable mınority Parliament, and therefore, an unstable government, (as seen during the period prior to the 2008) national political parties are motivated to vie for a majority of seats in Parliament in this way, the national political parties broker the needs of various regıons of the country internally, what has come to

\footnotetext{
${ }^{118}$ Soderlund et al, Media and Elections 72

${ }^{119}$ Soderlund et al, Media and Elections 72

${ }^{120}$ Since Confederation, and unt11 2008, Canada had been led only once by a coalition government, under the "Unıon Government' of Conservative Prime Minıster Robert Bordon which brought Conservatıves and Liberals together during World War 1, lasting from 1917 to 1920
} 
be called a "brokerage party system." ${ }^{121}$ As discussed in the introduction, a national party will attempt to adopt policy that attracts one region, without alienatıng another where it hopes to secure seats. The parties therefore, must find ways to bridge the two solitudes carefully during federal election campaigns. The role played by Quebec is significant, because it has a history of volatile voting patterns, putting its 75 seats potentially up for grabs at election time. Further, until most recently, Canadian majority governments throughout the country's history have depended on seats from Quebec.

This need, therefore, to reconcile policy with the needs of Quebec (or that will least alienate Quebec) is well understood by politicians vying for election. It is reflected in the way they organize communications for the media during political campaigns. The major parties typically have two separate organizations to handle media coverage. These separate organizations help the parties react to issues and events that are of interest to each particular audience. In the Canadian context, sometimes catering to one audience will get politicians in trouble with the other audience. Political journalists watch how well national leaders navigate thıs fault-line: get it right, and a leader can win

\footnotetext{
${ }^{121}$ Laura Stephenson, "Patties and Partisons The Influence of Ideology and Brokerage on the Durability of Partisanship in Canada," Voting Behaviour in Canada, ed Cameron D Anderson and Laura B Stephenson (Vancouver UBC Press, 2010) She wites "In its first incarnation, at the time of Confederation in 1867, the brokerage parties concentrated on bridging the linguistic and religıous cleavages between Ontario and Quebec; since then, the brokerage parties have expanded to encompass Western alienation and the regional interests of the Atlantic provinces, as well as the interests of central Canada the specific nationalist claims of Quebec The very nature of brokerage partıes prevents them from establıshıng a strong ıdeological program, whıch a party label could repıesent
} 
Canada through a majority Screw it up and strange thıngs happen on election day This was the story of the 2008 election campaign

\section{The Issue of Culture in Quebec}

During the 2008 election, the handling of one polıcy issue in particular, seemed to galvanize a significant amount of media attention in Quebec What had seemed to many a mınor cut to fundıng of the arts by the federal government became one of the definıng issues in the campaign coverage, as this thesis will show it is particularly Interesting if one considers that polls early in the campaign of 2008 suggested only $1 \%$ of voters in Quebec as well as the rest of Canada consıdered arts an important issue for the campaign ${ }^{122}$ An editorial in the wake of that election in the Victoria Times Colonist perhaps sums up a general lack of understandıng about how culture came to be so Important to Quebeckers, writıng "Quebec has given us the one-fınger salute Who could have thought that something as inconsequential as the Conservatives' cancellıng a few so-called artısts' travel grants（ ) could have made such a difference? ( ) after all, aren't there artists in other parts of Canada?"123

Many artists in the rest of Canada, in fact, tried in vain to get arts fundıng on the election agenda as it was in Quebec Yet, despite media events, communıques, and a

\footnotetext{
${ }^{122}$ Daniel Lessard, "Artıstes et politiques," Les Carnets, September 2008, accessed May 20, 2011, http / www radio-canada ca/nouvelles/carnets/2008/09/22/106240 shtml

123 'Harper must manage rising ant1-Quebec backlash How many times have we heard the question What does Quebec want?" Victoria Times Colontst October 22, 2008, accessed June 10, 2011 , http //www canada com/victoriatimescolonist/columnists/story html? id-53fc2f65-0b46-4159-badb $\underline{\mathrm{a} 160 \mathrm{afc} 677 \mathrm{c} 0}$
} 
YouTube campaign, ${ }^{124}$ only a single newscast devoted time to the issue of culture on The National and it appeared in the context of a media event being held by Quebec artists in Montreal Ironically, English artists received coverage in French in a report on the Telejournal discussing why the issue of cuts to arts fundıng was NOT resonatıng with voters outsıde Quebec The report featured Englısh artısts speakıng in admıratıon of how Quebeckers link the strength of their cultural Industries with the health of their natıonal identıty

The significance of the cultural industry in Quebec can be quantified As already discussed, in the francophone market, the broadcast viewing share of made in Canada programmıng (mostly made-ın-Quebec) is almost two thırds, where in Englısh, it is less than half In terms of spending on culture, Quebec recelved 30 per cent of culture expenditures from three levels of government in 2008, and 35 per cent of federal money according to an analysıs by Statıstics Canada From the federal government Quebec received $\$ 153$ per capita, the highest amount, compared to Ontarıo, which receıved \$112 per capita At the provincial level, Quebec doled out \$97 per capıta compared to Ontario which handed out $\$ 51$ per capıta ${ }^{125}$

Beyond the numbers, the importance of the culture industry can be seen in how the province reacts to Issues of "cultural sovereignty" The Quebec government has argued for power over its cultural and communicatıons industries "for the defence and development of Quebecois culture," according to politıcal scientıst Gaetan Tremblay

\footnotetext{
${ }^{124}$ Consider ivoteforculture com, launched in September 125 "Government expendıtures on culture, 2008/2009" Statıstıcs Canada, accessed August 11, 2011 http //www statcan ge ca/pub/87f0001x/2011001/t011-eng htm
} 
He describes the Quebec government efforts to protect its cultural industries under the North America Free Trade Agreement in order to "guarantee the maintenance and the unhindered evolution of our society as a dynamic element within the Canadıan and North American totality."126

The fight to keep Ted Rogers from buying out the Chagnon family's Videotron cable distribution company is another good example. Former Premier Jacques Parizeau weighed in on the issue saying the purchase was tantamount to "Toronto buying Montreal."127 The second largest shareholder in Videotron at the time was the publicly owned Caisse de dépôt et placement du Québec. ${ }^{128}$ The CaIsse - the province's pension holdings company -- vetoed the Chagnon family deal with Rogers citing "cultural sovereignty concerns." The Caisse then worked with Quebecor in a joint venture to purchase the company, leaving Rogers dans le froid. Parizeau helped found the Caisse in the 1960s, and many say the Videotron deal was motivated by Quebec nationalism more than business. ${ }^{129}$ It would be an ironic decision in retrospect, since the workers who contribute to the Caisse through their pension contributions - were subsequently thrown out into the street in the longest communications' industry lock-out in the

\footnotetext{
${ }^{126}$ Gaetan Tremblay, "Is Quebec Culture Doomed to Become American?" Canadtan Journal of Communications, 17, no 2 (1992).

127 "Videotron head slams Quebecor proposal," Broadcaster Canada's Communicatıon Magazıne, (Apr 2000), accessed June 17, 2011, http $/ /$ www broadcastermagazine com/1ssues/story aspx?and $=1000166382$ \&type $=$ Print $\% 20$ Archives

${ }^{128}$ The Quebec pension holdings company has a mandate to invest in Quebec-based industry

129 "V1deotron head slams Quebecor proposal "
} 
history of Quebec at that time. The next premier, Bernard Landry, publicly appealed for negotiations to end the dispute. ${ }^{130}$

Quebec politicians, as evidenced above, are sensitive to issues involving cultural industries - even when it involves the private sector. In advance of the election of 2008 , David Whissell, the Quebec Minister of Labour, wrote an open letter which appeared in newspapers throughout the province addressed to both sides in a Journal de Quebec ${ }^{131}$ labour dispute outlining his efforts to mediate and imploring both to get back to negotıations. He intervened again when the new owners of the Quebec television network, TQS, asked the CRTC in the spring of 2008 to allow it to eliminate newsrooms across Quebec and substantially cut its news programming in Montreal. That sparked a political firestorm centring on the CRTC's role in Quebec cultural industries, with all parties in the National Assembly supporting a motion demanding the federal government devolve the CRTC powers to the province. The issue created weeks of headlines during the summer of 2008 making cultural sovereignty a hot issue. It helped frame how Quebeckers would perceive the federal government's decision to cut $\$ 45$ million dollars from arts and culture ahead of the 2008 election campaign. What had seemed such an irrelevant campaign issue in the rest of the country was primed as an important issue in Quebec.

\footnotetext{
130 "Videotron head slams Quebecor proposal."

${ }^{131}$ Quebecor owner Pierre Karl Péladeau locked out workers at the Journal de Quebec in 2007, which became one of the longest running media lock-outs in Canadian history at 15 months, but that record was subsequently beaten with the lock-out at Quebecor's Journal de Montreal, which lasted a little over two years, finally reaching a settlement in early 2011
} 
These values and views on issues such as cultural sovereignty are reflected in news coverage. As suggested by Fred Fletcher: "It is reasonable to assume that news both reflects and reinforces the domınant social myths and symbols." ${ }^{132}$ Before this thesis goes further, however, consideration first should be given to the values and views of the journalists who make up those newsrooms. How do journalists' attitudes contribute to the decisions of their newsrooms and is there an historical difference between English and French journalists in Canada?

${ }^{132}$ Fletcher, "Media and Political Identıty," 365 


\section{Chapter 4 - Distinct Societies/Distinct Journalists}

"There is nothing surprising or scandalous in that journalists reflect the society in which they live. There's no such thing as objectivity. We get the media we deserve with their prejudices and weaknesses." - Robert McKenzie, Quebec City bureau chief for the Toronto Star, $1991^{133}$

This chapter will examine the differences among journalists workıng in French and English, how they see their roles, and how their views have been shaped by separate cultural and social forces.

The study of journalists has been an important theoretıcal field in journalism studies. The significance of news and its role in democratic societies, means the study of journalısm needs to consider the views of the people who make it, as described by media theorists David Pritchard, Paul Brewer and Florian Sauvageau: "Central to the understanding of any system's journalısm is an understanding of journalists' views about the importance of various social and political roles of the news media." 134 Inevitably, these values influence news outputs "because (these) views shape perceptions and the recognition of how things ought to be done."135

Pritchard (et al) consider the significance of "role theory" which suggests that news output will be affected by how journalısts see their own roles. This study of the journalısts' perception of their roles, according to the researchers, is important because journalists play such a vital role linkıng the people to their government, particularly in

\footnotetext{
${ }^{133}$ Diane Talbot, "Divided We Stand," Ryerson Review of Journalism, (March 1991)

${ }^{134}$ David Pritchard, Paul R Brewer, and Florian Sauvageau, "Changes in Canadian Journalists' Views about the Social and Political Roles of the News Media A Panel Study, 1996-2003," Canadian Journal of Political Science 382 (June 2005) 287-306

${ }_{135}$ Richard V Erıson, Patricia Baranek, and Janet Chang Negotiatıng Control A Study of News Sources (Toronto University of Toronto Press, 1989), 5
} 
the Canadıan context "( ) where the ties that bınd citızens together are straıned by the Immense size of the country, its strong regional character and its lack of common language and culture "136 The authors studied a cross-section of Canadian journalısts from the French and Englısh medıa in 1996 and again in 2003 to see how their values had changed over tıme The researchers found in their 1996 work five issues that most journalısts rated very important The researchers called it "the journalısts' creed " The issues included accurately reporting the views of public figures, getting information to the public quickly, giving ordınary people a chance to express their views, investigating the activities of government and public institutions, and providing analysis and interpretation of complex problems The researchers found in fact, that both Englısh and French journalısts matched in the level of importance they gave to these values But by 2003, the researchers found a statistically significant drop in "creed" values among Englısh journalısts ${ }^{137}$ They attribute the contınuıng strength of the "creed" among French journalısts to "the distınct professional culture of francophone journalısm " One sign of this professional culture, they suggest is the elevated membershıp among francophone journalısts to the professional group, the Federatıon Professıonelle des Journalıstes du Quebec (FPJQ), ${ }^{138}$ which "socializes journalısts to the profession and its Ideology"

\footnotetext{
${ }^{136}$ Pritchard et al, Changes 288

${ }^{137}$ Pritchard et al, Changes 288 The researchers found $23 \%$ of anglophone reporters, for example, lowered the importance of "accurately reporting the views of public figures from their declarations 7 years earlier

${ }^{128}$ Pritchard et al, Changes 302 The authors suggest half of journalists in Quebec belong to the FPJQ, compared to the small number of English Journalists who belong to the equivalent organization in English Canada, the Canadian Association of Journalısts
} 
Perhaps more sıgnificant to this thesis, is how equally francophone and anglophone reporters shared the values of the "journalists' creed" in 1996 -- one year following the Quebec referendum on sovereıgnty, when accusations of biased reporting - partıcularly at the French language Radio-Canada -- came from as high up as the Prime Minister.

While adherence to the so-called "journalist creed" values, crosses the language divide, and speaks to the professionalism generally of Canadian journalists -- these values operate in separate cultural news environments, which may partly explain the differences in news content Illustrated in chapter three. There are other journalistic values however, that may better explain some of these differences particularly in the area of national politics. These particular values evolved separately through the distinct cultural and social histories of French-and English-language journalists. These separate histories produced some distinct perceptions on important issues such as national identity; issues which inevitably affect coverage of federal politics.

Quebec journalist and chroniqueur, Lysiane Gagnon ${ }^{139}$ suggests a key value separating French and English journalists is whether they see their role as "informing" the public or "forming" the public. ${ }^{140}$ Gagnon wrote a submission to the Royal

\footnotetext{
${ }^{139}$ Lysiane Gagnon is an award winning journalıst, and has been writıng editorial columns for the Globe and Mal since 1990 She worked as a journalist for Le Jour, a nationalist paper run by then future piemier, Jacques Parızeau in 1974-75 She also worked as a Natıonal Assembly correspondent for La Presse Her editorials for La Presse during the referendum debate in 1980 tended to favour a moderate federalism She was asked to contribute an article to the Royal Commission on Newspapers for its volume The Journalists published in 1981.

${ }^{140}$ Lysıane Gagnon, "Journalism and Ideologies in Quebec," in The Journalists, Research Publication for the Royal Commission on Newspapers, Vol 2, (Ottawa. Ottawa, Supply and Services, 1981) 24 Note In the English translation of The Journallsts, Gagnon uses this expression "to form," which is a bit of a
} 
Commission on Newspapers (1981), which was published in a volume call The

Journalists In it she describes a journalistic environment in Quebec where great journalısts were more often edıtorialısts than reporters ${ }^{141}$ Former journalıst Peter Desbarats expands on thıs Idea, observıng "the marketable objectıvity of the rest of North American journalısm," is contrasted with a press of opınıons and analysis, where medıa stars are not "crusadıng ınvestıgatıve reporters" but rather columnısts and opınıon-makers ${ }^{142}$

The evolution of this difference is seen through separate cultural and social forces emergıng more than 150 years ago Gagnon offers a brief history of Quebec journalısts, suggestıng that in the 1800 s, francophone newspapers featured a kınd of opınıon or advocacy journalısm from the European French traditıon. While Englısh newspaper content during the perıod was evolving away from the partısan press, and driven by market interests, she suggests French journalısts thrived as opınıon-makers.

“French Canada's first great journalısts were, first and foremost, politicians and debaters This was, of course, a result of the fact that politics was, from the outset, the one field above all others in which outstanding French Canadians could assert themselves, since industry and commerce had been monopolized by the English since the Conquest "143

By the mid-20 $0^{\text {th }}$ century, journalısts in Quebec were influenced by the social transformation takıng place in Quebec through the Quiet Revolution In chapter two, this thesıs discussed the Impact of televisıon on Quebec society One of the co-foundıng

francization from the French verb "former" (noun "formation") which means in this case, "to train" or "to educate" in English

${ }^{141}$ Gagnon, "Journalısm," 24

142 Hazel, "The Media," 100

143 Gagnon, "Journalism," 219 
editors of Cite Libre, Gerard Pelletıer ${ }^{144}$ saıd television forced journalısts to become active participants in Quebec nation-building

"It was to a very large extent television that awakened the press The emergence of television in 1952 was in my view, our cultural revolution We began to express opınıons, to hold debates, and millıons of people were watchıng So the newspapers were obliged to follow suit and to express opınıons themselves "145

Although the "press of opınıon" gave way to the content needs of daıly newspapers and the same technological and market forces that shaped all North Amerıcan journalısm up to modern tımes, the "opınıon" element of the Quebec press persisted, accordıng Gagnon Natıonal polıtıcs, she writes, remaıned a prestıge job in journalısm and made up a large portıon of news coverage in Quebec compared to stories that domınated English news, such as the economy, taxes and energy issues She quotes the edıtor of the Quebec news magazıne L'Actualıte, Jean Pare who complaıned (Quebec) journalists "seek to influence rather than to reflect there are too many people who thınk and not enough who have seen" Gagnon describes this as "a contınuation of the need to "form" rather than to "Inform"146

The Royal Commission on Newspapers (1981) found the French press more closely tied to politıcs than the Englısh press, and that "analysıs, rather than sımple reportıng of events, domınates in the French language press "147 The Commıssion also

\footnotetext{
${ }^{144}$ Gerard Pelletier and Pıerre Trudeau founded Cite Lıbre which became an influential polıtıcal journal throughout the period

145 Hazcl, The Media 97

${ }^{146}$ Sregel, Politics and the Media 219

147 Royal Commıssion on Newspapers - Report, '(Kent Commıssion) (Ottawa Minıster of Supply and Services Canada, 1981)
} 
noted a cross-over between journalısm and politıcs among francophone journalists generally, statıng "there is a tradition of the movement of leaders between careers in politıcs and journalısm " As already discussed, the pattern contınues today

Another aspect of cultural and social forces that should be considered when examınıng the differences between French and Englısh journalists is how they saw themselves as workers Desbarats suggests "Quebec journalısts have a longer more turbulent and more profound history of union activity "148 Gagnon discusses how Quebec journalısts have been involved in the longest labour disputes in Canadıan history, and as already alluded to in chapter three, a brand of union militancy that contınues today Some theorısts suggest this is because francophone journalists have limited professional options in where they can work, and so fight to defend jobs in that province ${ }^{149}$ Gagnon writes "This is one factor ( ) which explaıns the desperate and sometımes almost suıcidal element of union milıtancy in journalıstıc cırcles "150 However, several significant disputes have been over editorial control of content, as described by Desbarats "Issues of principle, rather than money"151 The impact of these disputes on the larger Quebec society should not be overlooked The sıxty-eıght day producers' strıke at Radıo-Canada in 1958, accordıng Desbarats is "now considered one of the triggers of the Quiet Revolution of the

\footnotetext{
${ }^{148}$ Hazel, "The Media," 100

${ }^{149}$ Hazel, "The Media," 100

${ }^{150}$ Gagnon, "Journalism," 29

${ }^{151}$ Hazel, "The Media," 100 Durmg the 60 s and 70s, journalists, through therr professional organization lobbied the provincial government to control media managers through "news management committees" that would include journalists and members of the public
} 
1960 s "152 The producers were fightıng to belong to a separate Quebec unıon from other CBC workers in the rest of Canada Rene Levesque - a journalıst at the Corporatıon at the tıme - was arrested on the picket lıne He said later that the federal government's refusal to settle was a sign of indifference toward Quebec's cultural aspirations "the whole bloody French network became virtually nonexistent, and nobody cared "153 Levesque would say later the strike led to his own decision to become a sovereigntıst Journalısts' labour militancy was often supported by other elements of Quebec society During the 1971 strike at La Presse, 12,000 peoplemostly workers from other unions in Quebec -- defied a Montreal munıcıpal ban and marched in a show of solidarity A clash with polıce led to 50 arrests, and some suggest It also led to further entrenchment of unıon radıcalısm against the government of Premier Robert Bourassa ${ }^{154}$

This is not to say that unıonızatıon among Englısh-speakıng journalısts did not have a significant impact on the professional lives of workers Unionization by the 1960 s among Englısh journalısts was the standard, and few maınstream medıa organızatıons today have non-unıonized shops However, it is fair to say Quebec journalısts were at the vanguard of union militancy, with a focus on issues with broader implications for Quebec society as a whole, and with the support of whole sectors of that society How this distınction reflects how journalısts in Quebec cover the news versus their English colleagues is not clear, although Quebec reporters are seen by some

\footnotetext{
${ }^{152}$ Hazel, "The Media," 100

${ }^{15}$ Hazel, "The Media," 97

154 'La Presse Strike," The Canadian Encyclopedia, accessed May 30, 2011, http //www thecanadianencyclopedia com/1ndex $\mathrm{cfm}^{2} \mathrm{PgNm}=$ TCE\&Params=AlARTA0004402
} 
theorists to accept more widely collective rights over individual rights, as well as

favouring social democratic policy and government intervention. ${ }^{155}$

These historical differences described above illustrate how English and French journalists think about their own roles. A more recent study looks at how francophone and anglophone journalists think about the content of the issues they cover. In the wake of the 1995 referendum researchers Lydia Miljan and Barry Cooper surveyed journalists on a number of issues including their political beliefs. The authors argue: “In order to determine what 'ways of understanding' are in fact being disseminated, it is necessary to question individuals within media organizations who are in a position to make decisions about what counts as news."156 The goal of the research, they say is to find out "What moves the media? Are they driven by the profit motive, or do the personal backgrounds and idiosyncratic opinions of journalists make a difference in the type of news we receive?"157

During the winter of 1997 and 1998, the researchers interviewed French- and English-speaking journalists from mainstream news organizations. ${ }^{158}$ They also sampled English- and French-speaking members of the public (non-journalists) in order to

\footnotetext{
${ }^{155}$ Gagnon, "Journalısm," 26, also Marc Raboy, "Medıa, Nationalism and Identity in Canada and Quebec," Res Republica 39 no. 2 (1997) 321 Note: good examples include Quebec journalists' support and defence of Bill 101, the language law, as well as the protection of Qucbec's cultural industries under NAFTA ${ }^{156}$ Lydia Anita Miljan and Barry Cooper, Hidden Agenda how journalists influence the news (Vancouver: UBC Press, 2003). 22.

${ }^{157}$ Miljan and Cooper, Hidden Agendas, 7.

${ }^{158}$ Miljan and Cooper interviews 123 English speakıng journalists from outlets including the Toronto Star and the Globe and Mall, as well as broadcasters such as CTV and CBC. The 55 French-speaking journalısts came from newspapers such as le Devorr and le Journal de Quebec as well as the Radio-Canada television and radio newsrooms. All journalists surveyed performed varied jobs, from reporters to editors, as well as anchors and producers. The survey also included 626 English non-journalists and 178 French non-journalısts.
} 
compare responses and assess whether journalists reflect or lead public opinion. ${ }^{159}$

particular interest to this thesis, Miljin and Cooper also compared the views of English journalists to their French colleagues, as well as the views of journalists working for the public broadcaster versus the private sector. The three issues examined include coverage of the economy, the partition of Quebec, and finally, the courts and social Issues. Among the three, the most pronounced difference between French and English journalists existed over the issue of the partition of Quebec. ${ }^{160}$ Specifically on the issue of national unity, the researchers found anglophone journalists supported the view that it is important to protect Canada from the threat of Quebec sovereignty. Francophone journalists on the other hand, tended to "uphold the legitimacy of Quebec nationalism." More specifically, among francophone journalists, 60 per cent surveyed said they identified themselves as Quebeckers first, even higher than the general Quebec population at 50 per cent. The vast majority of English journalists, 89 per cent, identified themselves as Canadians first. ${ }^{161}$ The research found no statistical difference between public and private news organizations; the differences were based solely on which language the journalist spoke. ${ }^{162}$ Where English journalists' views aligned with the views of English Canadians, francophone journalists tended to exceed (or lead) the francophone public in their nationalist views.

\footnotetext{
${ }^{159}$ Miljan and Cooper, Hidden Agendas, 67-68

${ }^{160}$ Miljan and Cooper, Hidden Agendas, 68 Note the right of a portion or portions of Quebec to exclude themselves from the geographic territory of Quebec (the partıtion of Quebec) in a post-YES referendum scenario became a matter of considerable controversy and debate where federalist interests defended the rights of northern Quebec natıves and even predominantly federalist/anglophone parts of the western region of Montreal to exclude themselves from a sovereign Quebec. It was an idea that was seen as a federalıst provocation, even among non-sovereigntist francophone Quebeckers who believed Quebec had an internationally sanctioned right to seek out legitımate means toward self-determination

${ }^{161}$ Miljan and Cooper, Hidden Agendas, 93.

${ }^{162}$ Miljan and Cooper, Hidden Agendas, 173.
} 
This nationalist Identification among Quebec journalısts goes back to the begınnıng of the natıonalıst movement Lysıane Gagnon talks about the relatıonshıp between Quebec journalists and the Partı Quebecoıs

"There was an ıdeological affinity -- a great many journalısts and PQ members were of the same generation, had been educated in the same places, shared a sımılar lıfestyle and interest "163

Following the 1976 election that brought the Partı Quebecols to power, a survey

found 79 per cent of journalısts voted for the PQ, whıle 66 per cent supported sovereignty ${ }^{164}$ Support for sovereignty by the Quebec population generally was substantially lower ${ }^{165}$

This supports an historical observation about journalists and their role as drivers In natıonalıst movements Natıonalıst theorıst Tom Naırn suggests studies of natıonalıty

"( ) have underlıned the crucial place of such professional strata in generatıng the identity shifts behind nationalısm it is teachers, clerics, lawyers, journalists and loose screws who cause the trouble far more than landlords, bankers, manufacturers or trade unıonists" 166

Yet, as this thesis discussed in chapter two, studies have repeatedly found no bıas in reportıng even durıng periods of political crisis As well, this chapter illustrates that adherence to professional "creed" values is equally high among French and English journalısts Gertrude Robınson alludes to this professıonalısm in her study of the 1980 referendum, where she suggests Radıo-Canada "abrogated its 'natıonal unıty' mandate

\footnotetext{
${ }^{163}$ Hazel, The Media," 98

${ }_{164}$ Robinson, Consti ucting the Quebec Refer endum, 187

${ }^{165}$ In the 1980 referendum on sovereignty, $404 \%$ of Quebeckers supported sovereignty

${ }^{166}$ Hazel, "The Media," 95
} 
to live up to its professional goal of neutrality" This commitment to neutrality described by Robınson comes as a result of the much more complicated set of audience belıefs in francophone Quebec during the sovereignty referendums Journalists were faced with three publics those voting YES, NO and "uncommitted"167 One veteran Quebec reporter interviewed by medıa researcher Kathryn-Jane Hazel complaıned following the 1995 referendum, that Englısh reporters do not share the same dynamics

\footnotetext{
"In French, both sovereignty and federalısm are assumed to be valid options that deserve fair treatment In English, federalısm is assumed to be good and sovereignty evil 999 per cent of Englısh-speakıng (reporters) are openly federalists What kınd of society would Quebec be if the same was said of French-speakıng journalısts? At the very least, it would be a society whose media is completely divorced from it From that angle, I let you judge where fairness and objectivity is mostly found "

Despite these differences in audiences, critıcısm of francophone journalısts particularly by their English colleagues -- has centred on how French reporters perceive their role, as described earlıer to "form" versus to "inform." Peter Stockland, now retıred, covered the Natıonal Assembly for two years, but durıng the Meech Lake Accord constitutional negotiations he worked as a reporter with the Toronto Sun ${ }^{168}$ He told medıa researcher Diane Talbot at the tıme "The francophone press has a tribal perspective - the idea that we're doing this story by, about and for our people as opposed to doing a news story "169
}

\footnotetext{
${ }^{167}$ Robinson, Constructing the Quebec Referendum 51

${ }^{168}$ Stockland later became the Editor-1n-Chief of the Montreal Gazette from 2000 to 2004

169 Talbot, "Divided We Stand"
} 
Durıng the intense coverage of the negotiations for the Meech Lake Accord, at a first mınısters' conference, Stockland says a senıor Quebec Natıonal Assembly correspondent asked the premier of Quebec

"'Why are we contınuing with this taponnage (screwing around)?' I cannot Imagıne an Englısh language reporter askıng that kınd of question You might say, 'What do you hope to achieve here?' or 'Isn't this a little bit fruitless ?'ו170

Talbot wrote about the coverage of the Accord, and suggested French journalists saw their role as actıve players in the bulldıng of Quebec society as well as defenders of that society "In the francophone media, unconditional acceptance of Quebec's demands quickly became the focus of debate ( ) So evident was the francophone media's eagerness to pass the Accord unchanged that even Premier (Robert) Bourassa questioned their objectivity"171

William Johnson - a federalıst columnıst with the Montreal Gazette - said the francophone journalısts, Instead of pointıng out legıtımate reasons for rejectıng the Accord, "sımply saw criticisms as rejections of Quebec "172

However, Robert McKenzie, Quebec City bureau chief for the Toronto Star, at the tıme saıd "There is nothıng surprisıng or scandalous in that journalists reflect the society In which they live There's no such thing as objectivity We get the media we deserve with their prejudices and weaknesses "173 He suggested journalısts reflect the values of the societies they serve As seen earlier in this chapter, the general "journalist's creed"

\footnotetext{
${ }^{170}$ Talbot, "Divided We Stand"

171 Talbot, "Divided We Stand"

172 Talbot, "Divided We Stand"

173 Talbot, "Divided We Stand"
} 
values are highly respected by both English and French journalists. The values they differ over reflect their separate social and cultural backgrounds.

\section{Media 'Gatekeeping' and 'Agenda Setting'}

This thesis has been discussing the historical social and cultural differences between journalists as well as exploring their values and how they perceive their work. This context becomes significant when considering the media's role in "agenda setting" and "gatekeeping." Soderlund et al in Media \& Elections in Canada define the gatekeeper as "any social institution, social context, activity or thing that has, as a consequence of its characteristics or behaviour, the effect of modifying media content." Further the authors write: "all media and media organizations work within the context of a culture which forms their operational environment." In this way French and English language newsrooms operate within separate and very different cultural contexts as their "operational environment," affecting the selection of news content. As agenda setters, the media select news within this context, and "here may lie the most important effect of mass communications: its ability to mentally order and organize our world for us." ${ }^{174}$ This fuller and refined understanding of the CBC and Radio-Canada and its journalists is a necessary precursor to the next chapter's consideration of the differences in 2008 election coverage provided by Le Téléjournal and The National.

${ }^{174}$ Soderlund et al. Media and Elections in Canada, 33-35. 


\section{Chapter 5: Coverage of the 2008 Federal Election Campaign}

The Conservatıve Party, in many respects, did very well in the federal election of 2008, partıcularly outsıde Quebec. It ıncreased its standing in Parliament, gainıng 19 seats from 2006, most at the expense of the Liberal Party. It increased its support from minorities and women, and became the leading party in Ontarıo. ${ }^{175}$ The number one factor accounting for the Conservative Party growth was voter turn-out. As already mentioned, turn-out dropped to an historical low in 2008 to 58.8 per cent. ${ }^{176}$ Even the Conservative Party saw a drop in voter support of a little over 165,000 votes or 3 per cent from 2006, but the Liberal Party suffered the worst losses with the disappearance of more than 835,000 former Liberal voters - an 18 per cent drop from $2006 .{ }^{177} \mathrm{~A}$ significant change in favour of the Conservatives took place in Ontario where the party picked up 11 of its 19 new seats. In Canada's biggest province, the party went from 35 per cent popular support in 2006 to almost 40 per cent in $2008 .^{178}$ The Conservative gains came with very few actual additıonal voters from 2006 . The Conservative success

\footnotetext{
${ }^{175}$ Faron Ellis and Peter Woolstencroft, "Stephen Harper and the Conservatives Campaign on Their Record," in The Canadian Federal Election of 2008, ed Jon H Pammett and Christopher Dornan, (Toronto Dundurn Press, 2009), 16

${ }^{176}$ Although several publications reported 59 1\% turn-out following the clection, Elections Canada's final result was 58 8\% "Official Votıng Results 40th General Election 2008, Table 4 Voter Turnout," Elections Canada, accessed June 1 1, 2011, http //www electıons ca/scripts/OVR2008/dcfault html 177 “Official Voting Results $39^{\text {th }}$ General Election, Table 9 Percentage of valid votes by political afflilıatıon," Elections Canada, accessed June 16, 2011, http //www elections ca/scripts/OVR2006/default html and "Official Votıng Results 2008,40" General Election, Table 9 Percentage of valıd votes by polıtical affilıatıon," Elections Canada, accessed June 16, 2011, http /www elections ca/scripts/OVR2008/default html, also "2008 Canadian Electıon Results," Simon Fraser University, accessed June 16, 2011, http //www sfu ca/ aheard/elections/2008-results html 178 "Official Votıng Results," Elections Canada
} 
In Ontarıo came courtesy of the half a mıllıon elıgıble voters - mostly previous Liberal voters in Ontario - who "went $\mathrm{AWOL}^{\text {"179 }}$ on election day.

Table 1: Party Standings

\begin{tabular}{|c|c|c|c|}
\hline Party & Election 2006 & At Dissolution 2008 & Election 2008 \\
\hline Conservative Party & 124 & 127 & 143 \\
\hline Liberal Party & 103 & 95 & 77 \\
\hline Bloc Québécois & 51 & 48 & 37 \\
\hline New Democratic Party & 29 & 30 & 0 \\
\hline Green Party & 0 & $1^{180}$ & 2 \\
\hline Independent & 1 & 3 & 0 \\
\hline Vacant & 0 & 4 & 308 \\
\hline Total: & 308 & 308 & \\
\hline
\end{tabular}

*Source: Elections Canada

In the end, however, the Conservatives failed to achieve the "dream of a majority, ${ }^{181}$ which had seemed within reach at the beginning of the campaign.

As suggested by political scientists Faron Ellis and Peter Woolstencroft, 'Ultimately, the Conservatives won the election in the 'rest of Canada,' but lost their majority in Quebec." 182

179 "2008 Canadian Election Results," Sımon Fraser Unıversıty

${ }^{180}$ Liberal MP Blair Wilson left the party to sit as an Independent, however, during the summer of 2008, joined the Green Party of Canada Because of the election call, he never sat in Parliament as a Green MP He would have been the first In 2011, Elizabeth May, the Green Party leader became the first to be actually elected to Parliament

${ }^{181}$ Ellis and Woolstencroft, "Stephen Harper,"17 
In Quebec, at first blush, it appeared as if not much had changed between the 2006 and 2008 election, but a closer look at the results tells a different story. For one thing, Conservative popular support in Quebec dropped in 2008 from its gains in 2006. In 2006, for the first time since the 1980s leadership of Brian Mulroney, the Conservatives beat the Liberal Party as the federalist party of choice for Quebeckers. However, with the 2008 vote, its support slipped behind the Liberals again. ${ }^{183}$

Further, the Conservatives were not able to take advantage of the significant drop in support for the Bloc Québécois, whıch received approximately 173,000 fewer votes in 2008, an 11 per cent slide from $2006 .{ }^{184}$ The Bloc also dropped to 38.1 per cent of the vote in Quebec in 2008 from 42.1 per cent in 2006 but the drop did not significantly affect the number of seats it held. In the end, the Bloc won 49 seats, just 2 fewer than the previous election. The Conservatives - who had been hoping to win 2030 seats from Quebec in 2008 -- hung on to 10.

Polls at the beginning of the 2008 campaign predicted a very different outcome. A few weeks before the campaign began, a CROP poll showed the Bloc eleven points behind its 2006 result. The Conservatives had caught up (Bloc: 31 per cent versus the Conservatives: 30 per cent), and as suggested by political scientists Eric Bélanger and Richard Nadeau "The real prospect of making significant gains in Quebec was arguably one of the main reasons Harper decided to ask Canadians to go to the polls a full year

\footnotetext{
${ }^{182}$ Ellıs and Woolstencroft, "Stephen Harper,"17

183 The Conservative Party went from winning close to 25 per cent of the total vote in Quebec in 2006 down to 217 per cent, behind the Liberals at 238 per cent Elections Canada

${ }^{184}$ In retrospect, this large drop in support for the Bloc was a harbinger for things to come in the 2011 election, where the party was almost wiped out, losing official party status
} 
before the legal end of his term." ${ }^{185}$ Some pollsters in the initıal weeks of the campaign even suggested Stephen Harper and his party could be headed for a majority government. $^{186}$

Much of this Conservative gain came from efforts to court Quebec voters durıng the previous session of Parliament. As a minority government, the Conservatives spent the $39^{\text {th }}$ Parliament shoring up support in key demographics and regions, among them, women voters, minoritıes, and Quebec. ${ }^{187}$ In Quebec Prime Minister Harper promoted "open federalism." The government increased participation for Quebec in Canada's International delegation to UNESCO. It also gained popularity among Quebeckers following the passage of its motion in the House of Commons declaring "the Québécois form a nation within a united Canada." ${ }^{188}$ But perhaps most concretely, it resolved one of the long-standing grievances with the Quebec government over what Quebec had characterized as a growing "fiscal imbalance" in transfer payments. The Harper government resolved the issue by handing over an additional \$3.6 billion in new money

\footnotetext{
${ }^{195}$ Eric Bélanger and Richard Nadeau, "The Bloc Quebecois Victory by Default," in The Canadian Federal Election of 2008, ed Jon H Pammett and Christopher Dornan, (Toronto Dundurn Press, 2009), 136 and 152 The "legal end of his term," refers to the fixed election date set in new legislation - the first fixed date set for October 2009

186 "What would PM do with majonity?" The Toronto Star, Sept 13, 2008, accessed from Angus Reid, June 5, 2011, http //www angus-1eid com/wp-content/uploads/archived-pdf/star majority pdf

${ }^{187}$ Ellis and Woolstencroft, "Stephen Hai per," 17

${ }^{188}$ In November, 2006, the Bloc Québecois had orıgınally promoted a motıon calling for Quebec to be recognized as a nation The decision by the Conservatives to re-j1g that motion to include "within a united Canada" infunated the Bloc, and Gilles Duceppe threatened to vote against it. However, with enormous support for the motion in Quebec, the Bloc had little choice but to support it In the end the motion passed 266 to 16 . Ellıs et al, p35
} 
to Quebec in transfer payments; a move that annoyed much of the Conservative base elsewhere. ${ }^{189}$

The Bloc Québécors, on the other hand, began the campaign facing a number of challenges. The sovereignty movement had suffered a blow following the 2007 Quebec provincial election when the Parti Québécois received only 27 per cent of the vote, losing even official opposition status in the National Assembly. Further, the new official opposition party -- the Action démocratique du Québec (ADQ), was a conservative leanıng party whıch began fosterıng allegiances with the federal Conservatives following that election. ${ }^{190}$ Bloc leader Gilles Duceppe's personal popularity waned following a decision in May 2007 to leave the federal party and join the leadership race to head the Parti Québécois. However, Duceppe changed his mind just 24 hours later when polls suggested he would have come a distant second to Pauline Marois. ${ }^{191}$ To add to the Bloc's problems, on the eve of the 2008 federal campaign, it had become the target of several very public attacks from sovereigntists about the party's relevance to the nationalist movement. ${ }^{192}$

However, during the 36-day campaign, the fortunes of the two parties reversed (see figure 1) with profound consequences on the result, proving the political strategists' adage: "campaigns do matter." Bélanger and Nadeau concluded, "the fact

\footnotetext{
${ }^{189}$ Bélanger and Nadeau, "The Bloc,"138 The outcry came partıcularly following the 2007 Quebec election, when the Premier, Jean Charest, handed a significant amount of the new money over to Quebec taxpayers as a tax cut contributıng to the fallıng out betwcen the Prime Minister and the Premier of Quebec 190 Bélanger and Nadeau, "The Bloc," 156

191 Bclanger and Nadeau, "The Bloc," 140

${ }^{192}$ Including a letter published in a Quebec newspapet from former PQ minister Jacques Brassard, attacking the federal party for leaving sovereınty off its 2008 campaign agenda. Belanger and Nadeau, "The Bloc," 145
} 
that thıs progression deprived the Conservatives of makıng the gains they needed to form a majority government is perhaps the key feature of the 2008 election "193 As already described, former Conservative speech writer, L lan MacDonald blamed Conservatıve misfortunes on the Bloc and the medıa ${ }^{194}$ In the dyıng days of the campaıgn, the (eventually defeated) Conservative candıdate in Quebec's Sherbrooke ridıng, Andre Bachand offered thıs explanation "Stephen Harper has done so much for Quebec, but that's not the message that got through In terms of Communications 101, the Bloc won the campaign"195 Since these messages are mediated through coverage by Canada's news organizations, exactly how that discourse unfolded on Le Telejournal and The National is the subject of the following analysis

\section{Televisıon Coverage Le Telejournal and The National}

Canadians stıll obtaın most of their election informatıon from televisıon news ${ }^{196}$ An Ekos Research Associates poll at the end of the 2008 campaign found 82 per cent of Canadians stıll either "somewhat" or "exclusively" rely on televisıon news for campaign Information verses 79 per cent who rely on print sources and 52 per cent who look to the internet ${ }^{197}$ The $\mathrm{CBC} / \mathrm{SRC}$ newscasts have been cited as "the single most relıed" on

\footnotetext{
193 Belanger and Nadeau, "The Bloc," 152

${ }^{194}$ L Ian MacDonald, "The woolng of Quebec will recommence at dawn," The National Post Oct $_{16}$, 2008, accessed June 7, 2011, http //network nationalpost com/np/blogs/fullcomment/archive/2008/10/16/1 1an-macdonald-the wooing of quebec-will recommence-at dawn aspx

${ }^{195}$ Belanger and Nadeau, "The Bloc," 137

${ }^{196}$ Chrıstopher Waddell and Chrıstopher Dornan, "The Medıa and the Campaign" in The Canadıan Federal Election of 2006 ed Jon H Pammett and Christopher Dornan (Toronto Dundurn Press, 2006), 225

${ }^{197}$ Waddell, "The Campargn in the Media 2008," 220
} 
newscasts by their respective language audiences. ${ }^{198}$

Ratings during the debate support this with Radio-Canada attractıng 736,000

viewers to the French-language debate, compared to 676,000 watching its maın

competitor TVA according to BBM ratings research. ${ }^{199}$ The $\mathrm{CBC}$, however, lost the

ratings war for the English debate against CTV, attracting 889,000 viewers ${ }^{200}$ compared

to CTV's 1.03 million. ${ }^{201}$ However, CBC beat CTV in election night coverage. ${ }^{202}$

\section{8 by the Numbers}

Over 25 days $^{203}$ of electıon coverage Le Téléjournal and The National diverged on

a number of issues. In general terms, the story of the U.S. economic meltdown

dominated both newscasts in the last three weeks of the campaign. The National led its

program with stories on the economy in 17 out of 25 newscasts, followed by election

coverage that typically began with reaction from politicians to economic stories. Le

\footnotetext{
${ }^{198}$ Waddell and Dornan, "The Media and the Campargn (2006)," 228-229

199 "Debat des chefs," Richard Therrien, accessed August 11, 2011,

http //blogues cyberpresse ca/therrien/2011/04/14/debat-des-chefs-baisse-dauditone/ Another 171,000 watched Radıo-Canada's cable news network RDI and 66,000 watched on TVA's cable news network LCN

${ }^{200}$ According to CBC Corporate Communications, BBM ratıngs suggested 889,000 viewers watched the two hour debate on the CBC network whıle 365,000 watched on the cable all-news channel Newsworld ${ }^{201}$ According to CTV Corporate Communications, an average 103 millon viewers watched the debate peaking at 13 million Its press release suggests CBC's ratıngs were at 853,000 viewers in contrast to the 889,000 reported by CBC Corporate Communications

${ }^{202}$ The CBC network as well as its all-news specialty channel Newsworld (as it was called in 2008) attracted a combined audience of 2431 million vieweis at its peak on election night in 2008, compared to its main competitor, CTV along with its all-news channel CTV Newsnet, which peaked at 1785 million viewers "CBC's election coverage grabs and holds Canadians' attention," CNW, accessed June 15, 2011, http //www newswire ca/en/releases/archive/October2008/16/c6763 html In French, the private network, TVA won the ratıngs war with 714 thousand viewers compared to SRC's main network with 437, 000 viewers Richard Therrıen, "Électıon, la victorre à TVA," Le Blogue de Richard Ther nen, accessed June 15, 2011, http//blogues cyberpresse ca/therrien/category/cotes-decoute/page/2/ Note that since Quebec represents 23 per cent of the Canadian population, its rate of consumption of the federal clection results is significantly higher if ratıngs are any indication

${ }^{203}$ The campaign is actually 36 days, but it includes weekends when the two programs do not broadcast.
} 
Téléjournal led with the economy 12 out of 25 newscasts. The issue of culture only resulted in two reports on The National, where the same issue warranted more than a dozen full reports on Le Téléjournal. In this way, some of the general divergences observed during previous research described in chapter three are seen during the federal election campaign of 2008. In particular, English news coverage features more stories on the economy while French media tends to focus more coverage on issues of language and culture. ${ }^{204}$

As the $\mathrm{CBC}$ rules highlight, campaign coverage must be monitored for fairness by an outside observer. While Erin Research has been monitoring balance and farrness for both French and English services since 1993, beginning 2004 the public broadcaster decided to use two separate organizations to do this analysis. In 2008, Erin Research based in the Toronto area did the analysis for the $\mathrm{CBC}$, and the Universite de Laval's "Centre d'études sur les médias," based in Quebec City did the job for SRC. Comparing results from the two are challenging as each use different methodologies in complling their data, and focus on different aspects of the coverage. ${ }^{205}$ Despite this, there are some areas that make comparison worthwhile for the purposes of this analysis.

\footnotetext{
${ }^{204}$ For instance, Canadian researcher Fred Fletcher sums up the findıngs on federal elections statıng "French reports pay more attention to constıtutional and language issues while the English news gives greater coverage to economic issues ( ) The most strikıng differences show up in coverage of constitutional issues and symbolic events or matters related to language and culture "Fletcher, "Medıa and Political Identity," 366

${ }^{205}$ Erin Research for instance weighed coverage of issues such as the economy and culture, while the Centre d'etude did not. On the other hand, the Centre d'étude compared Radıo-Canada to several media organizations in its market, not just TVA, while Erın Research mostly compared CBC to CTV throughout the bulk of its analysis.
} 
In terms of covering the parties, the greatest difference appeared in the handling of the Bloc Québécois and the New Democratıc Party. During newscasts, 3 per cent of the proportion of statements and interview time ${ }^{206}$ referred to the Bloc on The National. Le Téléfournal included the Bloc in 18 per cent of its total coverage, or 6 tımes more. ${ }^{207}$ On the other hand, The Natıonal devoted 17 per cent of statements and interview tıme to NDP ${ }^{208}$ while Le Téléjournal featured the NDP in 13 per cent of its coverage. ${ }^{209}$ While it is true Canadıans outside Quebec can't vote for Bloc candidates - lımıtıng the party's relevance for audiences of The Natıonal - the 3 per cent accorded that party is somewhat lower than the 10 per cent public support it represented nationally on election day. The NDP had limited relevance for audiences of Le Téléjournal, since the vast majority of viewers live in Quebec where that party had a single Member of Parliament. However the 13 per cent accorded that party by Le $T J$ Is more in line with the 18 per cent the party received on election day. This discrepancy in treatment of the parties appeared among the two programs direct competitors. CBC's competitor, CTV,

\footnotetext{
${ }^{206}$ Enin Research monitored total statements about the party, total statements about the party leader and total interview tıme (excludıng feature interviews with leaders ) The Centre d'études looked at all aspects together The Bloc coverage in the Erın Research findings ranged from 2 to $3 \%$ The researcher decided to pick the higher value in the case of the Bloc The NDP coverage 1esults according to Erin Research, however, ranged from a high of $25 \%$ for intervew tume to a low of $12 \%$ for statements referring to the leader In this case the researcher took the average of the three, or 17\% The Centre d'ecoutes amalgamated all forms of references to the parties in its research, but divided its findings between SRC Radio and SRC Television Television included two programs Le Telejournal at 2200 on the main network as well as Le Télejournal at 1700 on the all-news channel RDI The head researcher Daniel Giroux said the findings of the two programs were so similar the results appearing for both could stand legitımately as the results for each "Balance in News Coverage," Erm Research, 10-14, "Analyse de la couverture," Centre d'etudes sur les medias (specific information not publicly avalable in the executive summary avaılable onlıne, however, obtaıned directly through the researcher Danıel Gıroux, Université de Laval )

${ }^{207}$ See note 31

${ }^{208}$ As mentioned in note 31 , this figure is an average of statements about the party, statements about the leader as well as interview time See note 31

209 "Analyse "Centre d'études sur les medias, (portıon of report obtained directly from the researcher) See note 31
} 
devoted 2 per cent of coverage to the Bloc and 18 per cent to the NDP according to Erin Research. TVA, according to the Centre d'études, committed 20 per cent coverage to the Bloc and 7 per cent to the NDP, suggestıng TVA is far more regional in coverage than SRC. (See table 2.)

$\underline{\text { Table } 2 \text { - Coverage of the Parties }}^{210}$

\begin{tabular}{|c|c|c|c|c|}
\hline Broadcaster & $\begin{array}{c}\text { Coverage of the } \\
\text { Conservative Party }\end{array}$ & $\begin{array}{c}\text { Coverage of the } \\
\text { Liberal Party }\end{array}$ & $\begin{array}{c}\text { Coverage of the } \\
\text { Bloc Québécois }\end{array}$ & $\begin{array}{c}\text { Coverage of the New } \\
\text { Democratic Party }\end{array}$ \\
\hline The National & $42 \%$ & $27 \%$ & $3 \%$ & $17 \%$ \\
\hline CTV & $43 \%$ & $35 \%$ & $2 \%$ & $18 \%$ \\
\hline Le Téléjournal & $40 \%$ & $26 \%$ & $18 \%$ & $7 \%$ \\
\hline TVA & $47 \%$ & $25 \%$ & $20 \%$ & $18 \%$ \\
\hline
\end{tabular}

*Source findings from Erin Research and Centre d'etudes sur les medias reports on balance following the campaign See note 31

These are the broad differences between the two programs during the campaign period. For the following qualitative analysis of the campaign coverage on Le Téléjournal and The National, the 36 day campaign has been broken up into three sections.

${ }^{210}$ Compled through a comparıson of Erin Research and Centre d'études sur les medias. For information on methodology see note 31 


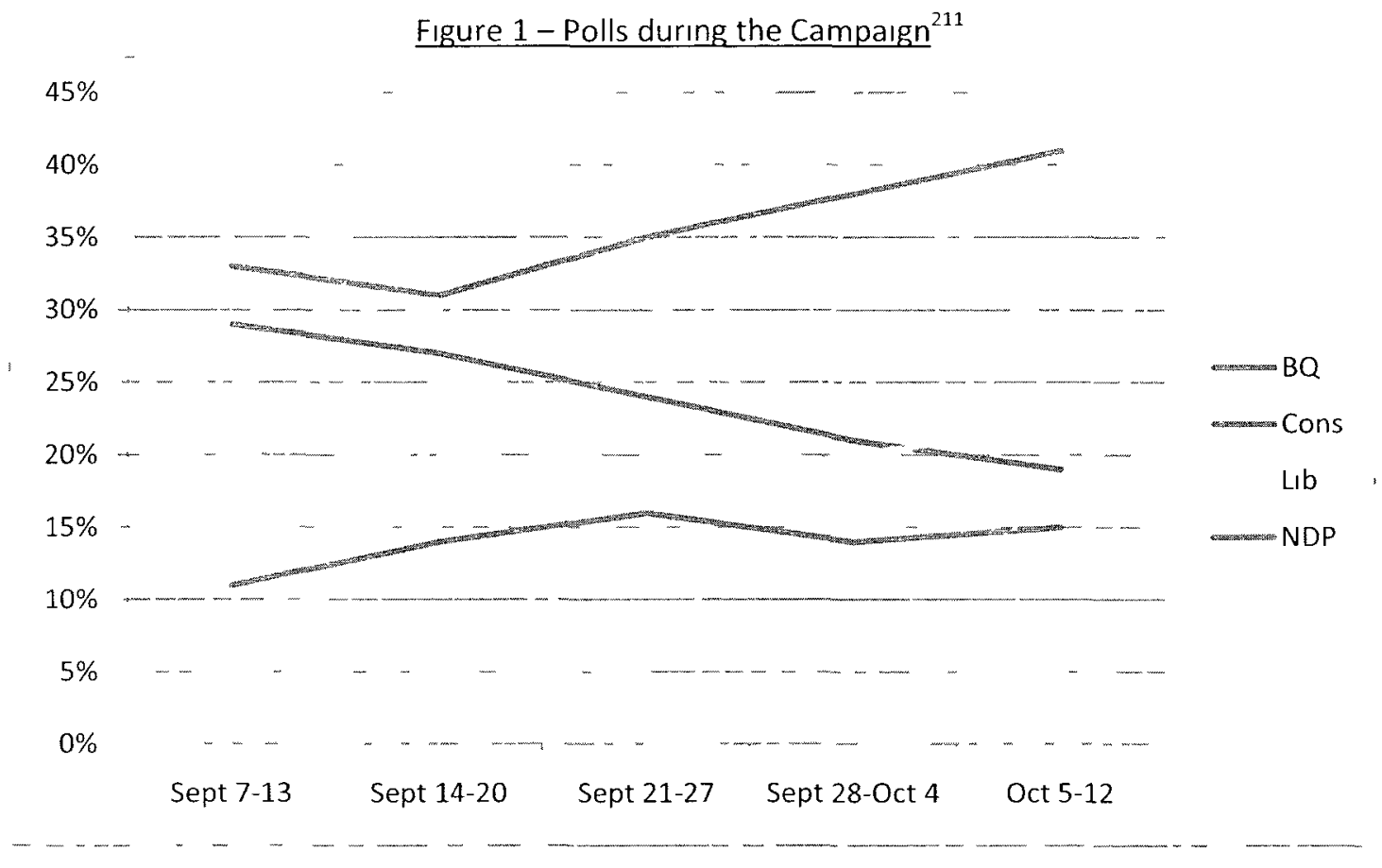

*Source 90 polls from Nanos Research, EKOS, Harrıs/Decıma, Ipsos, Leger Marketıng, Segma, Crop and Strategic Counsel, sample sizes vary

Using Figure 1 and its breakdown of party support in Quebec polls during the campaign, the first section will analyze coverage during the beginning of the campaign, when Conservative fortunes were highest in Quebec. The second part will begin when a viral internet video first appeared on YouTube on September 18, and was reflected in Quebec newscasts during the third week of the campaign. The third and final section will begin with coverage following the leaders' debates in French (October 1) then English (October 2) and continue through the last week of the campaign to election day.

This examination looks specifically at election coverage on the 60 minute weeknight newscasts which aired at 10 o'clock in September and October on the main

${ }^{211}$ Bélanger and Nadeau, "The Bloc,” 145 
$\mathrm{CBC}$ and SRC networks. The analysis will provide some general comments on coverage during each of the three sections, then focus on a couple of specific campaign days, and finally outline the major themes established during that period.

\section{SECTION ONE - CAMPAIGN BEGINS}

On the morning of September 7, Stephen Harper met the media gathered in

front of the Governor General's residence after asking for the dissolution of Parliament.

Another Canadıan election campaign had begun:

"Between now and October 14, Canadians will choose a government to look out for their interests at a time of global economic trouble. They will choose between direction or uncertainty; between common sense or risky experiments; between steadiness or recklessness." 212

In French Stephen Harper added:

"We promise to practice open federalism, ${ }^{213}$ the fiscal imbalance is resolved, and the debate over Quebec sovereignty is way down on the agenda -- way down on the agenda of even sovereigntists themselves." ${ }^{214}$

Until election day, Radio-Canada's Le Téléjournal, and the CBC's The National

featured the campaign as a central element of each newscast, on average devoting 10 -

15 minutes of each program to the campaign, typically with an election news package,

\footnotetext{
${ }^{212}$ See full Harper's specch at the launch of the campaign "Ả la conquête du Quebec," Radıo-Canada, September 7, 2008, accessed June 11, 2011 http //www radiocanada ca/nouvelles/Politique/2008/09/07/003-Elections-Harper shtml?ref=rss

${ }^{213}$ As described by Belange and Nadeau, "The Conservatıves made surprising inroads in the province of Quebec, winnıng ten seats in 2006 after having pledged "open federalısm, meanıng an approach to federalprovincial relations that would be more respectful of the provinces' (particularly Quebec's) powers and interests " Bélanger and Nadeau, "The Bloc,"137 Further, according to Ellis and Woolstencroft, "The Conservatives' national unity agenda was centred on its policies of open federalism and designed as a branding and outreach exercise." Ellis and Woolstencroft, "Stephen Harper," 35

${ }^{214}$ From Harper speech at launch of the campaign, see "À la conquête du Québec."
} 
and distributing election features ${ }^{215}$ throughout the hour. The election news sometimes led newscasts, however, during this period, the story that eclipsed other stories on newscasts around the world was the international market turmoil induced by the cascading failures of some of the United States' largest financial institutions, as well as the subsequent multi-billion dollar bail-outs by the U-S government. Most Canadian newscasts covered this story, leading a substantial number of programs in both languages throughout the 36-day campaign. (See table 3)

\section{Table 3: Economic Crisis during Campaign $2008^{216}$}

I------During the 5 wks of the campaign, the TSX dropped more than 4000 points, the Cdn $\$$ dropped $\$ 0.10$

\begin{tabular}{|c|c|c|c|c|}
\hline $\begin{array}{l}\text { Week } 1 \text { - Sept 7-13 } \\
\text { International markets } \\
\text { begin to spiral with } \\
\text { looming failure of } \\
\text { Lehman Brothers as well } \\
\text { as near collapse of Merrill } \\
\text { Lynch and AIG Insurance. }\end{array}$ & $\begin{array}{l}\text { Week 2-Sept 14-20 } \\
\text { Markets continue to } \\
\text { meltdown and ol prices } \\
\text { spıke as Hurricane lke hits } \\
\text { the Gulf of Mexico. }\end{array}$ & $\begin{array}{l}\text { Week } 3-\text { Sept } 21-27 \\
\text { US law proposing bail-out } \\
\text { package struggles } \\
\text { through Washington. } \\
\text { Markets continue to } \\
\text { panic. Merryl Lynch } \\
\text { Canada publishes report } \\
\text { predicting financial crisis } \\
\text { in Canada. }\end{array}$ & 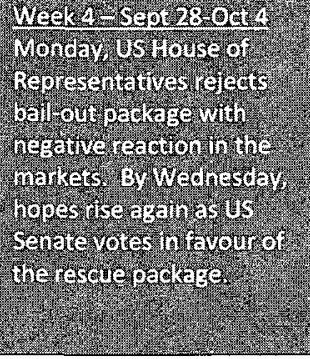 & 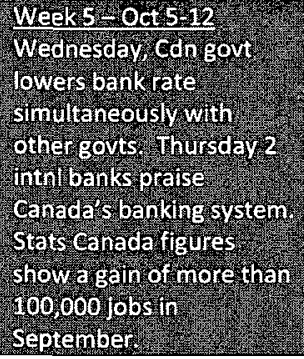 \\
\hline
\end{tabular}

As a result, during the first two weeks of the campaign, very few newscasts on The National and Le Téléjournal led with election news. During the second week of the campaign, The National led each day with international news - whether it was markets

\footnotetext{
${ }^{215}$ Features for both programs included reality checks, interviews with the leaders, panel discussions, riding and region profiles, etc.

216 "Balance in News Coverage," Erin Research, 6-7. (From "Notable Events")
} 
or oll prices. ${ }^{217}$ Le Téléjournal also featured the economy high in newscasts but also led with Quebec-centric non-election news stories. ${ }^{218}$

Despite the international context, however, the programs differed in their election news content from the first day forward. Story line-ups rarely overlapped, and when they did, story focuses differed between the two programs. The launch day of the election was a good example.

\section{Day 1 , September 7 -Close - Up}

On that first day, September 7 , both newscasts led with the launch of the election campaign. It was one of the few days during the campaign that both programs featured virtually the same line-up, introducing their election team of reporters assigned to cover the major party leaders. In this way, the line-up offered a good demonstration of how consistently the two programs differed in story focus.

What becomes immediately apparent for viewers comparing the two shows was Le Téléjournal's emphasis on how issues affect Quebec compared to The National's broader focus. This regional preoccupation of Le Téléjournal supported the findings of previous analyses of the French network, as discussed in chapter three.

\footnotetext{
${ }^{217}$ In the fall of 2008 , the spectacle of the collapse of some of the U S 's largest financial institutions was made worse by Hurricane Ike hitting the Gulf of Mexico - home to a substantial number of oil drilling operations The subsequent impact on gas prices broke into the campaign on this week

${ }^{218}$ During these initial weeks, other stones leading newscasts in Quebec included an item about Ad-man Jean Brault (one of the few convicted of a crime in the so-called federal Liberal Party sponsorship scandal) helpıng the RCMP, as well as a lead story about the Quebec mafia, and a lead story featuring Quebec's Cardinal Turcott wanting the federal parties to consider the abortion issue
} 
Both programs began with stories about the Conservative Party. With Stephen Harper heading first to Quebec, both CBC reporter Paul Hunter and his SRC colleague Daniel L'Heureux discussed the significance of the province for Conservatives in the push to win a majority. Paul Hunter talked about speculation Harper's party hoped to gain 15 additional seats in the province. L'Heureux discussed the Conservative communication strategy aımed at Quebeckers. The Conservative message, he explained, focused on the Bloc Québécois' limitations as a party in perpetual oppositıon and highlighted the Conservatives' ability to resolve issues such as the so-called fiscal imbalance.

The next story on each line-up centred on the Liberal Party. The CBC's Susan Bonner discussed Stéphane Dion's leadership image with a clip from Dion saying "I love to be the underdog." SRC's Emmanuelle Latraverse reported on Dion's assertion that his "Green Shift" platform would help Quebec lead the country on the environmental file. It focused less on his leadership problem, and more on his appeal to Quebec voters. ${ }^{219}$ Latraverse used a clip of Dion saying in French: (translated) "cher Quebec, 1 am at least as natıonalist as Duceppe."

\footnotetext{
${ }^{19}$ Dion's public relations problem withın Quebec was qualitatıvely different from how he was perceived outside that province In the rest of Canada, Dion was not well known before his leadership of the Liberal Party, and in that way, may have been vulnerable to the Conservatıve narrative that he was "not-a-leader" In Quebec, he had been negatively associated as former Prime Minıster Jean Chrétıen's ideological pit bull on the Clarity Act, assigned to publicly attack sovereigntist arguments agamst its passage durnng the sensitıve post-1995 Referendum period As a result, according to Daniel L'Heureux, Dion was hated partıcularly by the sovereigntists Daniel L'Heureux, Interview, July 2011
} 
Coverage of the NDP in English on this opening day of the campaign focused on leader Jack Layton's vow that he was runnıng to be Prıme Mınıster The French versıon highlighted Layton's statement to Quebeckers "our values are your values"

The stories about the Bloc Quebecois differed significantly between the two newscasts In Englısh, the report did not focus on the issue of leadershıp as the previous reports had Instead it examıned the issue of sovereignty, though the Bloc did not discuss a plan for sovereignty in its 2008 platform The CBC's Nancy Wood discussed whether the Bloc's declıne sıgnalled wanıng interest in sovereignty in the province ${ }^{220}$ The SRC's Danıel Thıbeault hıghlighted the Bloc's 'us-versus-them' messagıng, that Harper politıcs are the politıcs of George Bush, with a hidden agenda to increase the use of guns, and take women's rights away in this way the SRC report focused on the content of what Duceppe saıd (to Quebeckers), while the CBC report focused on what he represented (to Canadians specifically, what was the level of the threat to natıonal unity )

As mentioned, the two programs produced very similar line-ups, except for the placement of the story about the Bloc Quebecois - which preceded the New Democratic Party on Le Telejournal

While the programs diverged from each other, they did not deviate very much from the agenda set out by the sources of campaign messages the politicians. Stephen

\footnotetext{
${ }^{220}$ The issue of sovereignty in 2008 was not part of the Bloc platform however, there is a consistent interest from the "Toronto desk" in stories that measure the level of interest in sovereignty among Quebeckers
} 
Harper at the outset in English focused on leadership ${ }^{221}$ while in French he spoke to Quebeckers about how his party served the interests of Quebec. The journalists' reports focused on those separate themes on the launch day, and beyond.

\section{Day 6, September 12 - Close Up}

There continued to be differences in story focus between the two programs throughout the first week, with a partıcular emphasis on Quebec issues on Le

Téléjournal. The Friday of the first week is highlighted here because of the entry of the Premier of Quebec in the campaign on the French network. This day also featured culture for the first time as a significant issue on Le Téléjournal. Meanwhıle, The National continued to show more interest in the economy and issues of leadership.

The National began its program with the international story of Hurricane Ike 222 building up to hit the Gulf Coast and its impact on gasoline prices in Canada. Then its election coverage began with a report surveying leaders' reaction to rising gas prices. ${ }^{223}$ Later in the show, returning to election news, The National highlighted the day's party policy announcements in copy stories. ${ }^{224}$ The program also featured a story about the significance of leadership in the 2008 campaign produced by senior correspondent Brian Stewart.

\footnotetext{
${ }^{221}$ Francophones received the same message through translation

${ }^{222}$ Hurricane Ike was building in the Gulf Coast, about to hit Texas, affecting the US domestic oul industry in the Gulf Coast, and gas prices at home Prices went up 13 cents a litre in some parts of the country ${ }^{223}$ The National's Keith Boag surveyed reaction to gas prices from the leaders

${ }^{224}$ One of the ways to determme the importance of a story is where it appears in a line-up The higher the story, usually the more important it is, especially with iegard to "the first block" before the commercial But another determmation of the level of importance of a story can be seen through its treatment Stories determined more important usually get assigned to a reporter and become a full "report" The copy and copy-with-a-clip are usually considered less important stories - although sometimes late-breakıng stories or stories difficult to access can also determine treatment
} 
Le Téléjournal began its newscast with non-election news. ${ }^{225}$ Like The National, it also began its electıon news package surveying leaders on rising gas prices. It also featured several policy announcements through copy and visuals. Then it diverged significantly from The National with a report from National Assembly correspondent Josée Thibeault about Premıer Jean Charest. The host of the program introduced the report saying: "And now, a new player in this election campaign: Jean Charest, and his demands for Quebec during this election." Thibeault began the report sayıng. "Jean Charest arrived as if he was in campaign mode..."226 In the report, the Premier demands the federal government cancel its cut to funding of the arts and culture and further, hand the money over directly to Quebec to manage. The report also featured the reaction of the Parti Québécois in support of the Jean Charest's demands. ${ }^{227}$ Le TJ election news package later included a "reality check" ${ }^{228}$ report by Catherine Kovacs on whether federal arts and culture funding had actually gone up as asserted by Stephen Harper, despite the $\$ 45$ million in cuts to one program. ${ }^{229}$ Kovacs concluded that in general, federal government spending in arts and culture had declined since the Conservative mandate first began. The National would not do its own "reality check"

\footnotetext{
${ }^{225}$ It led its newscast with a Quebec-centric story about Jean Brault, one of the few men convicted of a crime in the sponsorship scandal, and his decision to help the RCMP with further investigations It then featured the story of Hurricane Ike and nsing gas pices

${ }^{226}$ The provincial election campaign, in fact, began almost immediately following the federal election

${ }^{227}$ The PQ wanted the Premier to go further, however, the two parties appear together in the same story condemning the Conservatıves

228 "Reality check" reports are stories that attempt to analyse the true state of an issue or situation, often assessing the validity of statements said by opposing sides of an issue In the case of the federal government's $\$ 45$ million cut to culture programs, the arts community was concerned the cuts would have a significant impact on its industry, where the government suggested in total, programs to that department had actually increased overall

${ }^{229}$ The $\$ 45$ million would be cut from the Canadian Heritage Ministry's budget affecting its arts culture and new media branch It would, among other thıngs, cut training and funding for promotion of Canadian artists abroad The value of the cut for Quebec represented about $\$ 20$ million, according to the Premier
} 
on the arts and culture sector for another two weeks, but when it did appear, reporter Terry Milewski would come to a different general conclusion. ${ }^{230}$ Le Téléjournal capped its election package with an analysis by senıor political correspondent and National Assembly bureau chief, Michel Auger about the premier's motivations in getting involved in the federal campaign. ${ }^{231}$

\section{Day $11 / 12$, September $17 / 18-$ Close-Up}

The newscasts the following Wednesday and Thursday highlight not only the continuing divergence between The Natıonal and Le Téléjournal, but as well, a growıng interest in the culture story by the French broadcaster, compared to an emerging theme focused on political campaign gaffes by the English service.

On Wednesday, day 11 of the campaign, both The National and Le Téléjournal led the election portions of their newscasts with the same story -- already a rare occurrence since the campaign launch. Both programs featured a late-breaking story about federal Agriculture Minister Gerry Ritz. Ritz apologized for flippant comments he made in the midst of the listerıosis outbreak weeks earlıer. ${ }^{232}$ Following thıs story, however, the two program line-ups diverged.

\footnotetext{
${ }^{230}$ As this thesis will soon show, the report by Terry Milewski appeared on September 23, 2008 - the same day artists put on a special gala in Montreal to protest the program cuts

${ }^{231}$ The premier's interest in the campaign is further explored in the analysis section of this thesis

${ }^{232}$ A listeriosis outbreak inked to a Maple Leaf meat processing plant in Toronto led to 23 deaths durnng the summer of 2008 Agriculture Minister, Gerry Ritz apparently made light of the deaths duing a conference call in late August, saying "This is like a death by a thousand cuts Or should I say cold cuts" He then reportedly said he hoped the latest victım in PEI was Liberal Opposition critıc Wayne Easter The detals of the conference call were made public during the second week of the election campaign, with various groups and opposition leaders calling for Ritz' resignation For details, see Brian Laghı and Campbell Clark and Karen Howlett, "Harper stands by Ritz despite 'tasteless' jokes," The Globe and Mall,
} 
Le Telejournal launched into ${ }^{233}$ another story about the culture program cuts, this tıme hıghlightıng conflıct between Conservatıve candıdates and provıncıal cabınet minısters The report began with a statement by host Bernard Derôme that the culture Issue had become a "battleground" in the dispute between the federal and provincial governments In the report that followed, SRC journalist Daniel L'Heureux said in his voice over "The controversy is not lettıng up ( ) and it's becoming an issue in the election in Quebec " Lıke a harbınger of later statements made by the Conservative leader hımself, the report featured one Quebec Conservatıve candıdate in the Quebec City regıon characterızıng artısts as already "spoıled" through federal fundıng That clıp set up reaction from the Quebec mınıster responsıble for culture, Christıne St Pierre who suggested the Conservative candıdate didn't understand the file In the stand-up at the end of the Item, L'Heureux concluded that perhaps Harper hoped the middle class wouldn't care

The National did not do a story focusing on Quebec or the culture Issue Note that $\mathrm{CBC}$ reporter Paul Hunter -- assigned to the Harper leadershıp tour travelling through Quebec on this day - had already fronted the breakıng story about Gerry Ritz ${ }^{234}$ The story that followed the Gerry Ritz story in Englısh featured NDP candidate Dana Larsen appearıng on the now defunct website POT-TV smokıng a fist full of

September 18, 2008, accessed June 30, 2011, http //www theglobcandmail com/news/politics/ditcle 710865 cce

${ }^{233}$ Since the Ritz story was late breaking, it is quite possible the culture story was onginally planned as the lead election story on this particular day

${ }^{334} L e T J$ on the other hand reported on the Ritz story using reporter Daniel Lessard, saving $\mathrm{L}$ Heureux on the Conservative tour for the Quebec story 
marijuana joints - a story Le Téléjournal treated with some copy and visuals, but no full report.

The next day, day 12, with Harper's tour still in Quebec, Le Téléjournal led its election news with more focus on Quebec. The lead story featured Jean Charest delıvering a shopping list of grievances - contradicting Harper's assertion that the fiscal imbalance issue had been resolved. Once again, Charest insisted the federal money for culture should go directly to the provinces. The National led its newscast with two full reports with more reaction to the previous day's Gerry Ritz revelations. ${ }^{235}$ The Natıonal also aired a copy story about the Conservatives forced to apologize for comments made to a native man by a minister's aide $e^{236}$ - fitting in with a growing theme about campaign gaffes.

With Stephen Harper in Quebec The National did produce a story about Conservative aspirations in Quebec by Paul Hunter. It appeared later in the election news package. It highlighted the Conservative message to Quebeckers that its party can help Quebec, announcing new money for Canadian content for TV5 - Quebec. ${ }^{237}$ The TV5 - Quebec announcement appeared much higher - third story - on Le Téléjournal.

\section{SECTION ONE - THEMES}

\footnotetext{
${ }^{235}$ The first story included more political reaction from the other party leaders calling for Ritz to resign. The second story included angry reaction from people directly affected by the listeriosis outbreak - also calling for Ritz to resign.

${ }^{236}$ Darlene Lannagan, aide to the Minister of Transport Lawrence Cannon, was caught on tape by natıve protestors telling one member of event he could meet with the minister in his office "if you're sober " The Conservatives were forced to issue an apology for the remark

${ }^{237}$ TV5 - Quebec is linked to TV5 Monde, and is run out of Montreal by a non-profit consortium
} 
By the end of the first segment of the election campaign, key divergences had clearly emerged between The National and Le Téléjournal. Viewers looking for opportunities to assess The National's focus during the campaign could consider the subjects discussed each week on the "At Issue" panel (featuring host Peter Mansbridge in discussion with Chantal Hébert (a columnist with the Toronto Star and Le Devoir), Allan Gregg (a pollster with Harris-Decima) and Andrew Coyne (a columnist with Macleans Magazine).) By the second week, the key topics discussed on "At Issue" revolved around the campaign gaffes, as well as Liberal Party Leader Stéphane Dion's struggle with leadership. Rex Murphy's editorial report appearing at the end of day 12 also focused on campaign gaffes and Dion's leadership problem. Earlier in the week, The National's "Insiders' Panel" featuring former campaign insiders, dealt with how to run a campaign around a "wild card" issue such as the economy. The economy, leadership, and gaffes had become central themes for The National's coverage by the end of the first section of the campaign.

Le Téléjournal had already established a Quebec-centric interest in story focuses, including reaction from Quebec City's National Assembly. The program had also begun developing the culture issue as an important theme.

\section{SECTION TWO - "CULTURE EN PÉRIL"}

By the second segment of the campaign, these separate themes emerged as defining campaign issues as demonstrated through the line-ups of The National and Le Téléjournal. 
This period began with the release of a video called "Culture en Peril" (Culture in Peril) ${ }^{238}$ on YouTube soon after Les Gemeaux awards show (carried live on Quebec television ) The awards gala had featured a parade of artists appearıng at the podium slammıng the Harper government for the cuts to culture spendıng, and callıng for artısts to mobilize a protest around the Issue 239 "Culture en Peril" appeared four days later September 18 Withın hours it generated so many internet hits on YouTube, it made the YouTube list of "top viewed videos" - quite a feat for a French language clip 240 Independently produced with professional production values, it used well-known Quebec artists to deliver heavy doses of satıre critıcızıng the Conservative government's $\$ 45$ million cut to cultural programs

The video featured Quebec singer Michel Rivard in a skit where he appeals to a panel of bureaucrats in Ottawa for a grant to feature Quebec music at a festival in France - the kınd of grant targeted by the program cut The bureaucrats portrayed in

\footnotetext{
${ }^{238}$ "Culture in Danger (Culture en Perıl with subtitles)," YouTube, accessed June 11, 2011 , http / www youtube com/uatch\% $\mathrm{v}-$ Uhgv85m852Q, This is a version with English subtitles that appeared days after the first French-only version Collectively, the item received more than 1 millon hits by election day

${ }^{29}$ The gala was not an insignificant event, and visuals and sound-ups were used in a number of reports on Le TJ and other newscasts when refernng to the artists mobilization against the cuts The images appeared in the lcad story on Le TJ September 19 (about to be discussed) Durıng the gala held Sunday night, September 14 , on live television, Harper was severely criticized over the $\$ 45$ million dollars in cuts to the culture budget The host of Radio-Canada's popular (over 1 millon viewers) "Tout le monde en parle' Guy A Lepage was the first to express concern over the cuts and was seconded by actress Suzanne Clement, who yelled out 'Entendez-nous, M Harper'" as she got up to teceive her prize The strongest crowd rcaction at the event came when actor Vincent Graton called on artists to mobilize a protest around the issue Jean Charest was at the event, with the camera frequently going to him during these exchanges Charest appeared in the September 19 story (to be analyzed next) saying some artists may have been harsh, but were expressing themselves as part of a legitimate democratic debate For more background see Richard Therren, "Prix Gemeaux les artıstes enrage comme Harper," Le Solell, September 15, 2008, accessed July 15, 2011, http //www cyberpresse ca/le sole1//arts et spectacles/television et radio/200809/1 5/01-21278-prix gemeaux-les a1tistes enrages-comme-harper php

${ }^{240}$ By September 19 (withın 24 hours) "Culture en Perll" had reached 40 thousand hits, and by September 23 , half a milhon
} 
the video played to long-standing anti-English Canadıan stereotypes: they are unilingual English speakers with conservative values who insist the only culture they will promote is "Canadian" culture. The meeting degenerates when Rivard begins playing one of his most famous songs featuring the word 'phoque' (meanıng seal in French) which is misinterpreted by the English panel. A series of comical linguistic misunderstandings follow, including one panel member asking Rivard if he is a homosexual. Behind the bureaucrats are posters of Heritage Minister Josée Verner and Prime Minister Stephen Harper who appears with an American flag in the background. At the end of the skit, Rivard's grant is refused.

With close to 40,000 web hits in 24 hours, Quebec media antennae went up. French language journalists following the campaign began asking out loud why "Culture en Péril" resonated with Quebeckers.

\section{Day 13, September $19-$ Close-Up}

Le Téléjournal and The National diverged significantly September 19, the day after the video "Culture en Péril" appeared. In particular, this day highlighted the prominence of culture as an issue on Le Téléjournal - now the lead story of the day. In fact it preceded an international story making headlines around the world: the announcement of the U.S. government bailout plan for the banking sector. ${ }^{241}$ The National did not cover the culture issue at all.

\footnotetext{
${ }^{241}$ September 19 was the day the Bush government announced its ball out package The headline for AP matched many simılar headlınes internatıonally "Strugglıng to calm a financial hurricane, the Bush administration on Friday laid out a radical bailout plan with a jawdropping price tag -- a takeover of
} 
That evening, after domınatıng talk shows in Quebec all day, SRC's Guy Gendron produced a story about "Culture en Péril" for Le Téléjournal. The report included a telephone clip from one of the video's anonymous producers saying he had no party affilıatıon, followed by a clip from Conservative Quebec MP Lawrence Cannon refusing to respond to the attack. It then featured a clip of Premier Jean Charest defending artists for what he called their legitimate participation in a democratic debate. Interestingly, the report reflects on the video's underlying message with a clip from Prof. André Lafrance from the Communications department of the Université de Montréal. Lafrance asked:

(translation) "Is this a message about how the government cut money from culture, or that the federal government is filled with anglophones and they don't understand Quebec; here the issue has changed, right?"

Gendron concluded that whatever the message, it was quickly becoming the most popular video in Quebec if not Canada.

In stark contrast, The National led its news cast with the story of the U.S. government bailout plan for the banking sector. When The National finally got to its own election coverage, it featured a round-up of various party announcements treated through copy and clips covered with visuals from the leaders' tour pool feed. ${ }^{242}$ The first election report by Terry Milewski focused on the resignation of a second NDP candidate,

hundreds of billons of dollars in worthless mortgages and other bad debt "See "Radical ballout plan has a jawdropping price tag," American Press, September 19, 2008, accessed July 17, 2011 , http //www allstocks com/stockmessageboard/cgi-bin/ultımatebb cgl? ubb=get toplc, $f=14,1=004663, p=1$

${ }^{242}$ 'Pool feeds'are shared visuals and clips from dally planned events and media conferences that journalists have access to when coverng the leaders' tours 
again because of his appearance on POT TV ${ }^{243}$ The same story received a mention only through copy with visuals on Le Telejournal The story that led Le Telejournal did not even warrant a mention on The National

Significantly, the two services of the public broadcaster had more in common that day with their same-language market competitors than with each other Le TJ's private television competitor, TVA led its own campaign coverage with the story of "Culture en Perıl" while most of the mainstream English media did not pick the story up at all The National's maın competitor CTV Natıonal News also included a full report on the NDP embarrassment over POT-TV high in its line-up In the end, the story line-ups of the public broadcaster's two services mirrored those of the programs in their own markets more than each others' - a phenomenon already identıfied durıng previous analyses $^{244}$

Artists in Quebec seized on the momentum created by the popularity of "Culture en Peril," as well as the call to action at Les Gemeaux awards show and held a protest concert in Montreal the following Tuesday, September 23 With over 1000 people attendıng (ıncludıng a spıll-over crowd watchıng on a giant video screen in a park across the street,) SRC's Michel Auger identified it as the best attended campaign event to that

\footnotetext{
${ }^{243}$ Terry Mılewskı's report focused on Kırk Tousaw's resıgnatıon as a candıdate following revelatıons that he too had appeared smoking pot on POT-TV It came days after another BC candidate, Dana Larsen resigned his candidacy In this report, it showed Jack Layton appearing on POT-TV in an interview with Marc Emery of the Marıuana Party sayıng Layton was in favour of the decrimınalization of marıuana ${ }^{744}$ As identified in chapter 3
} 
point. ${ }^{245}$ Extensive coverage appeared on French-language 24-hour news statıons RDI

(SRC's all-news sister channel) as well as LCN (TVA's all-news channel). Liberal leader

Stéphane Dıon and NDP leader Jack Layton featured arts and culture as the issue of the

day. Dion appeared at his dally media briefing in B.C. surrounded by movie equipment

to announce support for the film industry, and condemned Harper's approach to the

culture issue. Layton flew into Montreal to be at the concert that night. Bloc leader

Gilles Duceppe attended the event as well.

Stephen Harper was in Saskatoon. When an English reporter asked Harper for

his reaction to the artists' protests ${ }^{246}$ at his daily media conference, Harper replied:

"I think when ordinary working people come home, turn on the TV and see a gala of a bunch of people at, you know, a rich gala all subsidized by taxpayers claiming their subsidies aren't high enough, when they know those subsidies have actually gone up -- I'm not sure that's something that resonates with ordinary people."

Minutes later, when French reporters asked for the Conservative leader to repeat the response in French Harper declined but it was too late. Harper's English statement and his refusal to repeat it in French would go on to be called his "double discours" throughout the rest of the campaign by his political opponents.

\section{Day 17, September 23-Close-Up}

\footnotetext{
${ }^{245}$ On September 23, 2008 as part of his dally e-mall feedback Michel Auger wrote "1000 persons at a concert protestıng cuts in culture (largest crowd of the campargn so far in Québec, at least, probably in Canada too) "Analysis of these leads follows this chapter

${ }^{246}$ In partıcular, Harper was talkıng about the Quebec Gémeaux awards, carried live on televisıon September 14, the weekend before "Culture en Peril" came out This is the "gala" Harper is referring to in his following statcment For more background see Richard Therrien, "Prix Gémeaux. les artıstes enragé comme Harper," Le Solell, September 15 2008, accessed July 15, 2011, http //www cyberpresse ca/lesole1l/a1ts-et-spectacles/television-et-radio/200809/15/01-21278-prix-gemeaux-les-a1 tistes-enrages-commeharper php
} 
A closer examınation of coverage that day shows the lead stories of the two programs alıgned as Quebec artısts gathered for their protest concert called "contre les coupures" (agaınst the cuts) - perhaps the largest campaign event to date It demonstrated once more how the story focuses tended to diverge on the (rare) occasions the two programs undertook the same issue

The Natıonal framed the defence of culture as a mobılızatıon movement growing across the country Peter Mansbridge opened with the statement

"the economy may be the number one concern among voters in this election -health care, the environment are up there too -- but culture is gettıng more attention than usual this campaign"

The report by CBC's Rosemary Barton introduced Englısh audiences to the video "Culture en Peril" for the first tıme - by then almost a week old and at half a million hits on YouTube Barton described the culture backlash as a growing election issue throughout Canada "but perhaps strongest in Quebec" CBC reporter Terry Mılewskı followed up with a "reality check" report weighıng the impact of the cuts to programs agaınst the government claım there had actually been ıncreases in spendıng Mılewskı came to a more neutral conclusıon compared to SRC's Catherıne Kovacs in her report two weeks earlier Durıng his stand-up Milewskı saıd "the cultural budget has not really been slashed as the oppositıon claıms nor has it been boosted as the Tories claım"

In contrast, Le Telejournal devoted more than 9 minutes to this single issue Anchor Bernard Derôme began by suggestıng "culture" had become a key issue in the campaign - "at least in Quebec" The lıne-up began with a story by Emmanuelle 
Latraverse which showed footage of a francophone reporter at the Harper media conference tryıng to get the Conservatıve leader to repeat his comments about "rich artısts" in French, and Harper refusıng to accommodate Latraverse then included a clıp of Bloc leader Gılles Duceppe accusıng Harper of havıng a "double discours" "Harper could not be further away from Montreal tonight," said Latraverse Subsequent stories In the lıne-up included a clip of NDP leader Jack Layton promısıng to restore fundıng if elected Then the line-up featured a "live" from the red carpet outside the on-going protest concert in Montreal, featuring SRC's arts and culture journalıst Tanya Lapointe The 'lıve hıt ${ }^{247}$ lasted four and a half mınutes, and included clıps of artısts slammıng the Harper government on stage at the event Lapointe Included a clip of comedian Danıel Lemıre sayıng "It would be nice if the Conservatives could present more than just the army abroad" Michel Rivard, the singer featured in "Culture en Perll," appeared in a clip tellıng the audience the video was made (translation) "in solıdarity with those who are victıms of the cuts (to programs) and future victıms, ( ) if we keep up this slide to the right in Quebec, films won't be made, artists will be muzzled ( )" The final story in the focus on culture on Le Telejournal took a self-reflectıve angle it examıned why this story had not gotten any traction in the rest of Canada It Included clips of Englısh Canadian film-makers, sıngers and actors Film maker Atom Egoyan suggested Quebeckers are more willıng to support culture because it is part of Quebecois identity Singer Martha Waınwright also appeared sayıng Quebeckers have a deep understandıng for why culture should be protected

\footnotetext{
${ }^{247}$ A live hit' is a real time cable, satellite- or microwave transmitted link up with a reporter live into a show from the scene of an event
} 


\section{Day 19 , September $29-$ Close Up}

Two days later, (day 19) the programs diverged sıgnificantly agaın, although both programs led with the economy ${ }^{248}$ Harper's approach to youth crime received special treatment on Le TJ Election news coverage on the French network began with two reports dealıng with the Conservatives "tough-on-crıme" platform SRC's Catherıne Kovacs used a clıp of Bloc leader Gılles Duceppe suggestıng Quebec had reached a consensus ("le consensus Québecors") about how to treat young offenders, addıng that under the Harper plan prisons would become "universıties for crıme." Harper responded in the report insisting a Conservative law would only deal with young offenders convicted of serious crimes. Next, a "reality check" report by SRC's VIncent Maısonneuve focused on Quebec's Youth Reform Program, humanızıng the issue through the experience of one young offender. Later in the program, Michel Auger offered analysis of how the young offenders' platform along with culture compounded the Conservatıves Image problem among Quebeckers. Auger also discussed how the polls began showing significant gaıns for the Bloc Québécoıs over the Conservatives in the province. ${ }^{249}$

The Natıonal's election coverage began with two reports on campaign gaffes First Keith Boag focused on NDP candidate Mıchael Byers' speech to journalısm students suggestıng the Alberta tar sands should be shut down - conflictıng with the NDP

\footnotetext{
${ }^{249}$ Interestıngly, Le Telejournal featured a Quebec-centrıc "reality check" on the economy, centering on how Quebec's massıve investment in infrastructure spending could buffer the province from the worst of the economic downturn

249 The most recent polls had shown the Bloc 9 points over the Conservatives, where they had been neck and neck a week prior Belanger and Nadeau, "The Bloc," 145
} 
platform. CBC reporter Paul Hunter followed with a story on Conservative candidate Lee Richardson's suggestion that ımmigrants were responsible for increasing crıme rates in Canada. Two copy stories followed, both on the same theme: the first about an NDP candidate, Andrew McKeever, using rude language on Facebook; the second about Liberal candidate Lesley Hughes comments from 2003 that Israeli and other international intelligence organizations knew about the 9-11 attacks before they happened. $^{250}$

The National did not focus on the Conservative crime platform. ${ }^{251}$ Interestıngly, this same day top English film and television performers met in Toronto to condemn the Harper government's cut to arts programs, however, a story on the event did not make it onto the line-up of The National.

The issue of Quebec and culture, however, dominated the weekly "At Issue" panel. The discussion began with pollster Allan Gregg explaining Harper's tactıcs of "wedge politics" pitted rural voters against urban elites. Chantal Hébert suggested the tactic backfired in Quebec. Andrew Coyne contradicted Hébert saying he felt Quebeckers were likely more concerned about the economy along with most Canadians, but Hébert defended her position, telling the English audience that Quebec is the one region in the country where "culture counts" and the Conservatives could lose votes over the issue. As demonstrated on this day, Chantal Hébert's contribution to The

\footnotetext{
${ }^{250}$ Dion was heavily criticized for his handling of the Hughes affair After calls for her resignation from the Conservatives and negotiations with the Canadian Jewish Congress, Hughes found out she was let go as a candidate through the media. For detalls see Bruce Campion-Smith, "Dion drops candidate over 9/1 1 remarks," The Toronto Star, September 26, 2011 , accessed July 17, 2011, http //www thestar com/FederalElcction/article/506806

${ }^{251}$ The platform on young offenders had actually been released on Monday, September 22, three days earlier
} 
National consistently highlighted the Quebec reality and its consequences for the show's audience. Viewers had few other opportunities to hear what was happening on the ground in Quebec, despite the implications on Harper's hopes for a majority.

\section{SECTION TWO - THEMES}

As illustrated by coverage on Le TJ, the issue of Harper's spending cuts to cultural industries was being transformed - now along with the Conservatives youth crime platform -- into a discussion about defending Quebec's identity and interests, reflected through comments by the opposition parties. The Liberal leader, Stéphane Dion toured the province on day 19, borrowing from the Bloc play book telling Quebeckers "Harper must be stopped." He even used Quebec identity language on the larger English Canadian audience. His clip appeared in Rosemary Barton's story that day:

"We need to stop this man. He wants to pit everyone against everyone:

Canadians against artists, but we are speaking about our identity."

The NDP retuned its message even earlier. By the end of the weekend following the appearance of the "Culture en Péril" YouTube video, the NDP paid for advertising on Montreal metro video billboards portraying the Conservatives as 'culture killers,' changing the party name in the ad from "les Conservateurs" to "les Conservatueurs" (tueurs meaning killers)

The main beneficiary of this transformation of meaning, however, seemed to be the Bloc Québécois.

Quebec pollster Raynald Harvey, the president of Segma Research, suggested during the campaign: 
(translation) "Normally $\$ 45$ million in cuts Isn't a big issue for voters, but by touchıng on culture, emotions start to come in, and for natıonalısts, questıons of Identity are fundamental" 252

By the thırd week of the campaign, the Bloc had packaged the culture spending issue with the Conservative's platform proposal for new tougher young-offenders legislation (unvelled Monday September 22) to form a ballot box question that asked voters to choose between "us" and "them " Consider Gilles Duceppe's statement to reporters the mornıng of September 24

"Quebec's visions and Stephen Harper's visions oppose each other That's why in Quebec, the vast majority thınk that, we must not give Stephen Harper a blank cheque We must keep hım in close check"

In the following weeks, Duceppe's rhetoric would get harsher and harsher agaınst the Conservatıves generally and agaınst Stephen Harper particularly On the eve of the debates, for instance, a story on Le Telejournal with a clip of Duceppe suggested Harper would reopen the abortion issue Harper denied the accusation in the report The story never appeared on The National, likely because it originated with the Bloc The polls following the thırd week began showıng an attıtude change among Quebec voters The Bloc Quebecois, floundering in the first week with stories on Le TJ about its relevance, rebounded now in the polls. By the end of the third week, the Bloc experienced a resurgence in the polls while the Conservatıves began losing momentum. ${ }^{253}$

\footnotetext{
${ }^{252}$ Denis Lessard, "Stephen Harper en chute au Quebec," La Presse October 10, 2008, accessed July 17, 2011, http //www cyberpresse ca/actualites/clections-federales/enjeux/sondages/200810/10/01 28193stephen-harper en-chute-au quebec php

${ }^{753}$ Belanger and Nadeau, "The Bloc," 145
} 
On The National, this middle section of the campaign featured a large number of reports about campaign gaffes, ${ }^{254}$ more often handled with simple copy on Le TJ. The economy deserved attention not just in news reports but in panel discussions as well as "reality check" features. Other than the contributions of Chantal Hébert, and some coverage of Quebec polls, audiences of The National did not see much of the story unfolding in Quebec.

\section{SECTION THREE - THE ROAD TO ELECTION DAY}

The final campaign segment covers the period following the leaders' debates through to election day. The divergences already present between the two programs continued through this period with some new differences - particularly in the treatment of the Liberal and Conservative leaders following the debates.

Often election debates can mark the turning point in a campaign. Certainly, millions of Canadians - French and English -- tuned in as demonstrated by the ratings for the two broadcasts. Stephen Harper had asked for more time during the debates to deal with economic issues, however, Stéphane Dion seemed to score most on the economy when he pulled out a five point economic plan to deal with the economic crisis during the French language debate. ${ }^{255}$ The polls reflected the two solitudes following the

\footnotetext{
${ }^{254}$ By the end of week three, s1x candıdates in eight days of varıous party affilıations came under attack some forced to resign - because of current or past deeds. "Balance in News Coverage," Erın Research, 6 ${ }^{255}$ David Herle on The National's "The Insiders" panel, Chantal Hebert on The National's "At Issue" panel, as well as Michel Auger during an analysis discussion on Le TJ each felt Dion's plan was what voters were looking for to calm fears about the unfoldıng crisis. Media scholar Chris Waddell also makes this observation about the 2008 French debate, suggestıng Canadians lacked confidence "It's that lack of confidence that Stephane Dion tapped into ( ) by announcing a five-point plan to address future economic problems ( ) (Canadians) sought confidence that their political leaders were aware of the pending downturn and realızed how scared the public had become ( )" Waddell, "The Campargn," 238-239
} 
debates, with Dion coming out on top during the French debate, and Harper winning the English debate. Following the French debate, Ipsos Reid found a plurality of viewers (mostly francophone) stating they felt Dion had won, looked the most prime ministerial, and offered the best policies. ${ }^{256}$ Angus Reid's poll came out with similar results for the French debate. ${ }^{257}$ Harper came in third or fourth place in the French debate depending on the poll. ${ }^{258}$ Following the English debate, Canadians (mostly English) told pollsters Harper won. Dion came in a distant third in the Angus Reid poll following the English debate. $^{259}$

During analytical discussion on Le TJ the following Tuesday (the final week of the campaign) senior correspondent Michel Auger noted the Liberals were going up a point a day in Quebec polls, while Harper was dropping a point a day. He also noted Dion seemed to have more passion in his campaign since the debate. But increased interest in Dion appeared on the English network as well. In a news report the Friday following the debate, $C B C$ reporter Susan Bonner mentioned a bump in polls for the Liberal leader, and included a quote from Dion saying "Harper can be beaten." The following Monday -

\footnotetext{
${ }^{236}$ Ipsos Re1d/CanWest News Service surveyed French-speakıng Canadıan voters who watched Wednesday night's French-language leaders' debate, findıng 40 per cent of those polled said Liberal leader Stephane Dion won the debate, with Bloc leader Gilles Duceppe at 24 per cent, Conservative leader Stephen Harper at 16, NDP leader Jack Layton at 11 and Elızabeth May at 1 per cent. Andrew Coyne, "Débats des chefs, premic̀res réaction," Macleans ca, accessed July 15, 2011 Macleans ca at http /www2 macleans ca/2008/10/02/debat-des-chefs-premiers-reactions/ ${ }^{257}$ Angus Rerd suggested more Canadıans watching the French debate said Dion was the winner at 32 per cent "Canadians say Harper won English debate, Dion the French version," Angus Reid, accessed July 15, 2011, http //www visioncritical com/wp-content/uploads/pdfs/2008 10.04 Debates pdf

${ }^{258}$ The result for Harper in the Angus Reid poll durng the French debate was worse than the result in Ipsos Reid Dion came in first with 32\%, then Duceppe with $27 \%$, followed by Layton at $16 \%$, Harper at $10 \%$, and finally Elizabeth May brought up the rear with $2 \%$

259 "Canadians say Harper won "Angus Rerd Harper was the clear leader in the on-line poll following the Englısh debate with 34\%, Jack Layton came in second with 19\%, followed by Stéphane Dion with 14\%, just a single point higher than the Green Party's Elizabeth May with 13\% Finally Gilles Duceppe recerved $1 \%$ support.
} 
the final week of the campaign, The Natıonal's Keith Boag noted at the end of his report that Dion was makıng "a surprisıng surge in the final days of this campaign" However it Isn't clear whether Dion's uptick in the polls during this period came in reaction to his performance durıng the debate or sımply the outcome of an accumulation of the selfInflicted wounds by the Conservative team particularly over the issue of the economy How the two programs dealt with the Conservative troubles showed once more, divergence between the shows

\section{Day 31, October 7, 2008-Close Up}

On this Tuesday of the final week of the campaign, the two programs diverged in many of the same ways shown to date Now, there also emerged a difference in the treatment of the leaders themselves, in partıcular, Stephen Harper and Stephane Dion

On this day, Harper unveıled the entıre Conservative platform in it he deviated from his "stay-the-course" program with a spendıng promıse to assist the manufacturıng sector $^{260}$ The Natıonal began its show with a political story about the platform by Keith Boag, includıng Harper's message with opposition reaction Later in the program, a closer look at the Conservative platform by Paul Hunter began with an intro from Peter Mansbridge sayıng that while much of the platform contained a lot of previously announced programs, "there were new ones today" The intro contrasted with the text read by Le Telejournal host Bernard Derôme for its report on the Harper platform

"The deepening economic crisıs and the recession - we now think will be inevitable - has not changed Stephen Harper's plans One sıngle economic

\footnotetext{
${ }^{260}$ Harper's Finance Minıster Jim Flaherty had already announced the same week the government would be anding the banking sector by buyıng up some mortgages
} 
measure was introduced (...) Stephane Dion volced today what many already think: "too little too late."

The National left much of the criticism of the Conservative platform to the other party leaders in the Boag report. Le TJ, however, also featured an analysis interview with senior correspondent Michel Auger who made the point himself. He suggested Canadians losing their pensions wanted more from the Conservative platform. He also made much of the fact that Harper waited so long to release it.

This day also featured longer one-on-one interviews with Stephen Harper. The interview lasted 12 minutes on Le TJ and 26 mınutes on The National. Both interviews concentrated more than two-thirds of their content to questions about the economy, but the two interviews diverged significantly as well.

\section{One-on-one with Stephen Harper - Close-up}

Both programs had feature interviews with each party leader. These interviews did not tend to coincide on the same day on both programs, however, this is what happened with Stephen Harper. Harper appeared on both Le TJ and The National Tuesday, October 7, (day 31) setting up a good opportunity to compare the two programs approach to interviews generally and the Conservative leader, particularly.

The interview with $\mathrm{CBC}^{\prime}$ 's Peter Mansbridge ${ }^{261}$ included several questions about Harper's decision to continue his "stay-the-course" message despite the international context, where governments around the world were intervening to stabilize their

\footnotetext{
${ }^{261}$ The National used a format where audience members gave pre-taped questions for the leader, however, Stephen Harper refused to partıcıpate in that format, and host Peter Mansbridge told audiences the day of the interview The National decided to acquiesce to Harper's demand for a simple one-on-one interview in the public interest
} 
bankıng systems Durıng this portıon of the interview Harper made a comment that would be used agaınst hım throughout the final week of the campaign Harper told Mansbridge the market spıral could actually present some good buyıng opportunitıes for Investors Mansbridge asked "are you sure you want to be sayıng that?" Harper defended his statement The opposition parties used the comment through the final week of the campaign to portray Harper as insensitıve to Canadıans either concerned about their retırement savings, or losing their jobs in the manufacturing sector Both the French and Englısh network used the clip from the Peter Mansbridge interview the final week in order to frame the opposition attacks

Another significant element of that interview took place toward the end, when Mansbridge asked Harper whether he regretted his comment on September 23 regardıng "rıch" artısts Mansbridge explaıned he asked the question because it had been suggested it may have cost the Conservative leader support in Quebec it was one of the few times The National raised the issue of culture as a significant factor in the upcomıng vote Stephen Harper saıd he dıdn't lıke the way the message had been "torqued," suggestıng a medıa influence He further saıd "I thınk I may have gotten baited into an argument instead of discussing our policies"

Le Telejournal's host Bernard Derôme had a somewhat more aggressive style with Stephen Harper Consider his first question

(translation) "Mr Harper, you made the decision to end your government's term, you're the master of this contest, you're the master of your platform, is it reasonable, is it even democratic, to wait untıl one week before the election to release your platform?" 
His second question asked hypothetically, should the economy get worse, (translation) "what's left, cut spendıng? You have no manoeuvring room ${ }^{\prime 262}$ On the issue of Harper's "stay the course" approach to the international economic situation, Derôme said his own son felt Harper "est trops cool " In the face of the crisis Harper remaıned calm throughout the Derôme interview, even in the face of questions such as "And where's the compassion in all of this?" On the culture issue, Derôme asked "You turned off a lot of Canadians - a lot of Quebeckers - with the culture question, what's the problem there?" Harper responded with a slightly different answer to the question on the same issue in English described earlier Harper said he felt there was a lot of "disinformation" and enumerated policy announcements in cultural programs

In general, It's fair to say the Mansbridge interview featured more neutral openended questions that began with how, why and what Mansbridge's first question asked “There's a lot of fear out there, people worried about their jobs, their savings, their homes, what do you personally do to try and Identify with those people" Compare that to Derôme, who on the same issue said to Harper, "people tell me they want you to be more reassurıng, you're their leader, afterall "This difference in style Illustrates the discussion in chapter four about journalists and how they see their roles

\section{Day 32, October 8, 2008 -Close-Up}

The following day demonstrated a growing divergence in the treatment of Stephen Harper and Stephane Dion by the programs in the final week Le TJ Included a

\footnotetext{
${ }^{267}$ The question referred to the Conservative platform that promised to not increase taxes, and not allow deficit spending Economists had been speculating on how much manoeuvring room that left the government without cuttıng program spending
} 
package of several reports depıctıng Harper and the Conservatives clearly in a defensive position, while Dion seemed to have momentum The National, however, did not portray Harper in as vulnerable a position

On this day the economy led both newscasts with international governments (Includıng Canada) sımultaneously lowerıng central bank interest rates to ensure the avallability of credit for borrowers The National began its election coverage with Mansbridge suggestıng "the issues have narrowed to one," the economy The report by senıor correspondent Keith Boag led with a Liberal event ${ }^{263}$ and focused on the Liberal message that the party has experience handling the economy durıng tough times Harper appeared in the item countering the Liberal message, suggestıng the Liberal "Green Shift" program would hurt the economy

Le Téléjournal also led its election coverage with a report on the Liberals highlightıng an invigorated campaign that had a more aggressive approach agaınst Harper It suggested Harper was on the defensive SRC reporter Philippe Leblanc added a passıonate clıp from Dıon to Quebeckers to joın hım ın beatıng Stephen Harper SRC's Daniel L'Heureux followed with a report in which he replayed Harper's clip from The National Interview with Mansbridge L'Heureux suggested Harper was still dealıng with the repercussıons of that remark The next Item by SRC journalıst Danıel Thıbeault featured the Bloc Québecois The report Included a media conference put together by the Conservative candıdates in the Quebec City regıon wantıng to "set the record

\footnotetext{
${ }^{263}$ The event included Paul Martın former Prime Minıster and Liberal finance minıster responsıble for consecutive budget surpluses
} 
straight" following repeated statements by Duceppe and the Bloc Québécois. "Ça dépasse les limites" (translation: "it's gone too far") complained Josée Verner - one of a handful of Conservative cabinet ministers from Quebec. By this time, Duceppe had been in reports suggesting the Harper government would bring back the abortion issue, calling Harper a liar, and accusing the Conservatives of engaging in cultural genocide. At the end of the report, Thibeault said Duceppe had been solidifying his message that Harper and the Conservatives values did not match Quebec values.

Finally, the election package ended with another analysis interview with Michel Auger focused on Harper's gaffe ${ }^{264}$ made during his interview on The National and its impact on the Conservative campaign in the final week. Auger went on to describe a transformation in Dion's campaign: "même son anglais est amélioré!" (even his English has improved!). Auger repeated Dion's message that perhaps he really could beat Harper: "reste à voir" (we'll have to wait and see). Auger suggested as well that the media conference by the Conservatives in Quebec City showed desperation; a sign the Quebec campaign was in trouble.

\section{Day 33, October 10, 2008 -Close-Up}

A one-on-one interview with Liberal leader Stéphane Dion by ATV (affiliated with CTV) in Halifax dominated this day's coverage. During the interview, Dion appeared uncertain over the meaning of a question about how to handle the economy and asked several times to have it repeated. ATV decided to show the interview unedited "out of

\footnotetext{
${ }^{264}$ Harper's remark that the downturn in the markets presented a buying opportunity had come to be considered a gaffe in both language media.
} 
publıc interest" despite makıng a commitment to Dion the producers would cut the repeated questions out $A$ lot has been written already about this incident, particularly over the ethics of the decision by ATV to renege on its deal with Dion and its subsequent Impact on the campaign just a few days before election day But there is another dimension to this incident - the two solitudes dimension - that is also significant for the purposes of this thesis

Daniel L'Heureux discussed the incident durıng an interview for this analysis L'Heureux had been assıgned to the Conservatıves durıng that fınal week, and on that day the Conservatives delayed the leader's plane in order to allow journalısts to watch the interview and see for themselves L'Heureux says he watched the interview and phoned his assignment desk

"I told them that I knew this was going to be a big story for the English media, and so we should cover it But in my opınıon, Dion was right about the question not being clear It wasn't even good Englısh But I looked around, and the Englısh media had already decided Dion looked lıke a fool "265

Then, accordıng to L'Heureux, at a point in the campaign when Harper was giving very few media scrums, he made a statement critıcızıng Dion performance, and suggested it showed further evidence Dion wasn't prepared to deal with the economy

The National did the story that day showing a clip of the gaffe, and (while CTV aired the clip of Harper's response) featured copy of what Harper had said On the followıng day, a report by Terry Mılewskı about the Liberal leader described Dıon's agenda in terms of "recoverıng from yesterday's gaffe"

${ }^{265}$ Daniel L'Heureux, Interview, July 12, 2011 
Le Téléjournal did the story similarly the first day. The following day, Philippe Leblanc's report showed the Bloc's Gilles Duceppe using the issue to bolster his attack on Harper and the Conservatives. Duceppe said it was a low blow when so many Conservative ministers struggle in French: "I always said there are two official languages in Ottawa: English and translation." In this way, while the incident seemed to bolster the "not-a-leader" characterization of Dion by the Conservatives through the English media, it seemed to provoke sympathy towards Dion as seen through the French media.

\section{SECTION THREE - THEMES}

During the final stage of the campaign, the two programs continued to diverge, now in new ways. The programs featured qualitative differences in their treatment of Dion and Harper in the final week, with Harper seen far more on the defensive on Le TJ versus The National, and at the same time, a much more sympathetic treatment of Dion appeared on Le TJ.

Not only did Harper have to fight attacks from Gilles Duceppe. Harper continued to be the target of a "guerre des mots" (war of words) from the Premier of Quebec on the Radio-Canada newscasts. Jean Charest appeared once more on October 6 in the final week with his shopping list of demands to the federal government. Harper tried to fight back saying Charest had his own political agenda with a provincial election looming.

This final period capped off a consistent pattern of divergence between the two networks programs in line-up, choice of stories, and story focus. 


\section{The Lead Project}

This analysis has shown major divergences between Le Téléjournal and The National during the campaign, including different focus as well as story choice. Did these two solitudes extend beyond the decisions of the senior line-up editors of the programs - in particular, to the working journalists following the campaign?

For 25 days of the campaign, two journalists, Michel C. Auger (lead political correspondent with Radio-Canada) and Julie Van Dusen (a veteran political correspondent with $\mathrm{CBC}$ ) participated in the research for this paper. At the end of each day, they wrote an e-mail with a subject line that read: "Today's Lead" revealing their own choice for what they thought should be the "lead story" for that day.

The following are sample leads chosen from some of the days highlighted already in this thesis.

\section{Day 11 - September 17:}

Van Dusen: "Bedeviled by the deficit-who can best keep Canada's boogeyman at bay" Auger: "Harper talks about culture in $Q C$, does not even mention his budget cuts, still very sore point with QC gut"

\section{Day 17 -September 23}

Van Dusen: "Culture cuts-does anyone care" Auger: "1000 persons at a concert protesting cuts in culture (largest crowd of the campaign so far in Québec, at least, probably in Canada too)"

Day 18 - September 24:

Van Dusen: "Battleground BC-could the Dion carbon tax blow the Liberals off the map?" Auger: "Polls show Liberals fourth in BC, third in QC while Bloc is on the upswing. Seems like that culture thing is not just a "Plateau" thing after all." 
Dav 32 - October 8:

Van Dusen: "Can Stephen Harper turn it around?"

Auger: "Harper takes fire from all sides on aftermath of his "there are bargains on the market" gaffe."

Many of these responses reflect the differences that appear on the program line-

ups of the two shows. For further analysis, answers from the daily leads were tabulated according to eight categories, including whether there is mention of four parties - the Conservatives, the Liberals, the NDP or the Bloc, or mention of the following issues: the Economy, Culture, Quebec or Other.

The results suggested the two overlapped predominantly through mentions of the Liberal and Conservative Parties. There were issues, however, where one dominated over the other, reflecting, in fact, coverage by their own media outlets. For example, CBC's Julie Van Dusen out-paced SRC's Michel Auger in mentions of the Economy by 2 to 1 . CBC's Van Dusen never mentioned the Bloc, where SRC's Auger mentioned the party on three occasions. The province of Quebec and Culture are both mentioned three times more by SRC's Auger. See figure 2 below:

This is in no way meant to be a scientific measure, but only an observation of how the senior working journalists assess leads, and how closely their views reflect the decision-making process of their larger organizations. 
Graphic: The Lead Project

\begin{tabular}{|c|c|c|c|c|c|c|c|c|}
\hline & Cons & Libs & NDP & Bloc & Econony & Culture & Quebec & Other \\
\hline \multicolumn{9}{|c|}{ WEEK\#1 } \\
\hline Daytiz & SwN2.5 & & & & & & & \\
\hline 42 & $\begin{array}{ll}V & A\end{array}$ & v & & & & & & $\mathrm{v}$ \\
\hline$\pi 3$ & $\begin{array}{ll}\mathrm{V} & \mathrm{A}\end{array}$ & & & & & & & V \\
\hline$\because t a$ & & & & $A$ & & & A & v \\
\hline 3,5 & $\begin{array}{l}\mathrm{V} \\
\mathrm{A}\end{array}$ & A & & & & & & \\
\hline 16 & A & & & & $\begin{array}{l}\mathrm{V} \\
\mathrm{A}\end{array}$ & & & \\
\hline \multicolumn{9}{|c|}{ WEEK\#2 } \\
\hline ha & A & & & & $\begin{array}{ll}\mathrm{V} & \mathrm{A}\end{array}$ & & & \\
\hline $1 \pm 0$ & & A & & & v & & & \\
\hline$\# 11$ & A & & & & v & A & A & \\
\hline Hi1.2 & & A & & & & & & v \\
\hline 413 & $\begin{array}{l}\mathrm{A} \\
\mathrm{A}\end{array}$ & v & & & & & & \\
\hline \multicolumn{9}{|c|}{ WEEK\#3 } \\
\hline 类10 & A & $\begin{array}{l}\mathrm{A} \\
\mathrm{A}\end{array}$ & & & & & & \\
\hline 指弪? & & & & & & $\begin{array}{ll}\mathrm{V} & \mathrm{A}\end{array}$ & A & \\
\hline$t: 18$ & & v & & A & & $A$ & $A$ & \\
\hline 419 & & & & & v & & & \\
\hline$\$ 20$ & & A & & & v & & & \\
\hline & & & & & & & & \\
\hline
\end{tabular}




\begin{tabular}{|c|c|c|c|c|c|c|c|c|}
\hline \multicolumn{9}{|c|}{ WEEK\#4 } \\
\hline & A & & & A & v & & v & \\
\hline 1 & $\begin{array}{ll}\mathrm{V} & \mathrm{A}\end{array}$ & & & & & & V A & \\
\hline 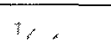 & i & $=\ldots$ & 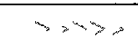 & $b=y^{n}$ & $\Rightarrow>>>n$ & $>\quad$ & $\begin{array}{ll}\mathrm{V} \\
\mathrm{A}\end{array}$ & $\rightarrow>x$ \\
\hline$\pm>0$ & 3 & $\therefore$ & $3>3-20$ & $x, \infty>>$ & $>>, \infty \infty$ & 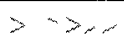 & $>>>$ & $>>>>>$ \\
\hline $1 / 7$ & & v & v & & & & & \\
\hline \multicolumn{9}{|l|}{ WEEK\#5 } \\
\hline si & V A & & & & V A & & & \\
\hline $73^{*}$ & $\begin{array}{ll}V & A\end{array}$ & & & & & & & \\
\hline 52 & V & & & & & & A & \\
\hline$+3:$ & & & & & & & & $\begin{array}{ll}\mathrm{V} & \mathrm{A}\end{array}$ \\
\hline 534 & & v & & & $A$ & & & \\
\hline Totals & 8 vs 13 & 6 vs 5 & 1 vs 0 & 0 vs 3 & 8 vs 4 & 1 vs 3 & 2 vs 6 & \\
\hline & Cons & Lubs & NDP & Bloc & Economy & Culture & Quebec & Other \\
\hline
\end{tabular}




\section{Chapter 6: Analysis of the 2008 Campaign Coverage}

As illustrated in the preceding examination, substantial differences existed between Le Téléjournal and The National in their coverage of the 2008 election campaign. The differences occurred in both focus and subject. In the end, the emerging themes produced profoundly different campaign narratives.

The opening day of the campaign offered a perfect example of differences in

focus. It was one of the only days where line-ups matched, and both had a full report on each of the main party leaders. However, stories on The National focused on leadership issues and Le TJ focused on Quebec-centric themes - particularly, what the parties offered Quebec.

The two solitudes emerged even more profoundly over story selection. Following the first day, the line-ups rarely overlapped. An issue featured high in the line-up by one would be either ignored or reduced to copy in the other. The treatment of the issue of culture and youth crime in Quebec on Le TJ versus campaign gaffes, the economy and leadership on The National are the best examples.

When the English broadcast finally did note the culture story, the report covered it as a Canada-wide issue, not as a Quebec phenomenon. Consider the Rosemary Barton report, for example, which included a French clip of Quebec singer Ariane Moffatt translated as "it's a hot issue because we're proud of our identity." Moffatt actually said: "c'est chaud parce que je pense qu'on a une identité unique et on est très fier" (it's hot because I think we have a unique identity and we're very proud.") (t's a subtle 
difference, but including the phrase "we have a unique identity" would have turned the protest into a particularly Quebec confrontation

Moreover, the line-ups and story treatment by the two broadcasters seemed to reflect their same-language competıtors more than each other This took place on September 19, when the video "Culture en Perıl" led Le TJ, while The Natıonal led with the economy and its election coverage focused on the emerging NDP problems over candıdates appearıng on POT-TV CTV Natıonal News did not cover the "Culture en Peril" story though it did have a report about POT-TV TVA, Le TJ's largest competitor In French meanwhile, led its election news package with the story of "Culture en Perıl" Interviews with journalists workıng with the English networks in Quebec say they flagged the story developıng in Quebec to assıgnment desks (mostly located) in Toronto At the same tıme, Radıo-Canada's assıgnment desk was well aware of the stories being developed by the Englısh services

Nancy Wood, The National's Montreal correspondent said she had been sent the video lınk to "Culture en Perıl" and knew from the chatter on the talk shows that this was developing into a story in Quebec She says she pitched the story for the program, but "they really weren't interested "266 Chantal Hebert, Toronto Star columnist on the weekly "At Issue" panel saıd she phoned Peter Mansbridge, the anchor of the program, to personally flag the story "It just wasn't somethıng that resonated with their viewers

\footnotetext{
${ }^{266}$ Wood was assigned to cover the Bloc in the campaign, and was the program's Quebec correspondent based in Montreal On that particular day she sard during an interview she had flagged the issue early but had been assigned a non-election story about how tainted milk from China had reached Canada Nancy Wood, Interview, July 10, 2011
} 
at that point," she said durıng an interview ${ }^{267}$ Both programs seemed to be guided by different news values, and as seen from the leads sent in by senıor correspondents, that separate sensibility is seen among the rank and file journalısts themselves

The campaign narrative that emerged in the end told different stories to different audiences Audience language, therefore, determıned which issues domınated the two services of the public broadcaster

\section{Who's Holding the Fiddle?}

It is also fair to suggest both programs followed the agendas of the politicians in determınıng the issues salient for voters In this way, the two solitudes exist with the messengers and their messages Consıder that in Englısh Canada, Stephen Harper outlıned in the begınnıng of the 2008 campaign that this would be an election about the economy, and more particularly, "proven leadershıp in uncertaın tımes "268 Although it Is more than likely The National's concentrated focus on the economy in the campaign came as much from the pull of world-wide events, the program did reflect the politıcians' agenda In Quebec, Stephen Harper delıvered a message taılored to Quebec audiences His speech in Quebec City the openıng day of the campaign focused on the opportunities for Quebeckers in supporting the Conservatıves and the impotence of the Bloc in delivering the goods to Quebec ${ }^{269}$ Le Telejournal's emphasis on measurıng how well the parties serve Quebec's interests can be linked in this way to the agendas set by

\footnotetext{
${ }^{267}$ Chantal Hebert, Interview, November 23, 2008

${ }^{269}$ L Ian MacDonald, “A Missed Rendezvous with a Majonty," Policy Optlons (November 2008), 26, accessed July 20, 201 1, http //www $1 \mathrm{rpp}$ org/po/archive/nov08/macdonald2 pdt

${ }^{269}$ Ellis and Woolstencroft, "Stephen Harper," 46
} 
politicians The Bloc had the obvious advantage of having a leader who firstly, never had to consıder the feelıngs of Canadıans outside Quebec, and secondly, could deliver the party message inside the province every day while other party leaders were lımited by their cross-country tours Other leaders were not only hampered in delıvering a consistent message shaped specifically for Quebec audiences, there were tımes when a message for another audience actually conflıcted with messages aımed at Quebeckers Tough-on-crime legislation and culture are two examples of this However, Quebec journalıst Michel Auger points out one of the big faılures of the Conservative campaign In Quebec was its inability to attract star candidates (translation) "the presence of a strong Quebec team of candidates could have compensated for this shortcoming it wasn't the case "270

As seen in chapter three, it is not uncommon for Canadian news organizations to be accused of following the agendas of the politıcians in their analysıs of an earlier period of elections, medıa theorısts Soderlund, Romanow, Briggs and Wagenberg concluded "( ) our data tend to characterıze the electronıc media as holdıng the fiddle for the politicians to play, rather than attempting to call the tune "271

Following the 2008 election campaign, Christopher Waddell's analysıs of media performance also found the media agenda contınues to be strongly controlled by the agendas of the politicians He suggests the media should abandon the leaders' tours, as they close off reporters from voters "captıves of the candıdates" He says "election

\footnotetext{
${ }^{770}$ Michel Auger, "Le Quebec du statu quo," Policv Options (November 2008) 33, accessed July 20, 2011 , http //www irpp org/po/ar chive/nov08/auger pdf

${ }^{271}$ Soderlund et al, Medıa and Electıons 72
} 
campaigns still run the way they did thirty years ago and the media dutifully tag along, reporting in the same tired way."272

\section{Quebec-Ottawa Relations}

In Quebec, it's clear from this analysis that a significant political actor is the premier himself. The premier of Newfoundland, Dany Williams, had a similar impact in 2008 on Newfoundland voters with his ABC campaign ("anything but Conservative"), but in Quebec, this provincial involvement in campaign coverage is more formalized.

Federal election media coverage in Quebec typically incorporates the elite political correspondents covering the National Assembly. For example, Michel Auger, the network's National Assembly Bureau Chief at the time, contributed the regular federal campaign analysis interviews for Le Téléjournal. Senior National Assembly correspondent Josée Thibeault covered the premier's involvement in the campaign from the very first week. ${ }^{273}$ During this particular campaign, Jean Charest appeared in reports on Le Téléjournal almost each week of the campaign usually in conflict with the messages coming from the Conservative party's Quebec campaign. (In contrast, the premier did not appear on The National.) Charest, himself in a volatile minority government position at the time, held off the Quebec election call while the federal election campaign dominated the airwaves. ${ }^{274}$ Reporters such as Thibeault, however, frequently described Charest as clearly in campaign mode. Journalist Michel Auger

\footnotetext{
${ }^{272}$ Christopher Waddell, "The Campaign in the Media 2008," in The Canadian Federal Election of 2008, ed. Jon Pammett et al. (Toronto: Dundurn Press, 2009), 253

${ }^{273}$ Thibeault's first report appears the end of week one, on Frnday, September 12, and focused on how the premier of Quebec had entered the race criticizing Harper on the culture issue before the issue had even been picked up by the BQ It was followed later in the show by an analysis by Michel Auger about what the premer had to gain by getting involved in the federal campaign.

${ }^{274}$ The Quebec provincial election took place on December 8, 2008.
} 
explained late in the first week of the federal campaign on Le Téléjournal that the Lıberal Premier had a dual interest in attackıng Stephen Harper's Conservatives. For one thing, the Conservatives - in lieu of much of a party infrastructure in Quebec ${ }^{275}$ - had aligned themselves with the conservative-leaning ADQ Party following the 2007 provincial election, abandonıng much of their relationship with Jean Charest and the Liberal "Big Red Machine." ${ }^{276}$ With the relatıonship cooled between the two leaders, Charest may have preferred Harper in a mınority positıon, matching his own volatılity in the National Assembly. For another thıng, the culture issue had given Charest an opportunity to set himself as the only true defender of Quebec interests.

Le Téléjournal did on some occasions break away from the agenda set by politicians. An example took place on September 16, when the lead election story featured an investigation of the dilapidated state of the federally-funded Champlain Bridge over the St. Lawrence River to Montreal. It Included responses from the party leaders on what they would do to fix the problem - a story picked up by the francophone print press the following day.

A joint Globe and Mail - CBC investigation appeared on The National on September 24, as well as October 8 suggesting the listeriosis outbreak had been known

\footnotetext{
${ }^{275}$ Since the Mulroney era, much of the federal Conservative Party presence in the province had disappeared

276 The Conservatıve leader had not been happy with Jean Charest after the Quebec premier turned around and handed the multi-billion dollar increase transfer payments from Ottawa as a generous tax cut to Quebeckers in order to attract votes during the 2007 provincial election campaign When the conservative leaning ADQ made a major breakthrough during that same election, becoming the official opposition over the Part1 Quebécois, the federal Conservatives began making ties with that party, Harper even attended an event with ADQ leader Mario Dumont in late 2007 By the time of the 2008 federal campaign, Jean Charest and his "Big Red Machine" were not workıng for the Conservatıves as they had in the previous election, and turned Charest into one of Harper's fiercest critics during the campaign See Ellıs and Woolstencroft, "Stephen Harper," 36, also, Bélanger and Nadeau, "The Bloc," 156.
} 
by the Canadian Food Inspection Agency long before it was reported to the public. However, the story appeared in the news section of the program, and did not elicit responses from the parties vying for election (Le Téléjournal picked up the story the same day.) To be fair, Le Téléjournal has the advantage of being able to take on very local Quebec issues that The National would never get away with without immediate cries of being irrelevant to national audiences.

\section{The Meaning of Culture during the 2008 Election Campaign}

Since one of the key divergences in coverage occurred over the issue of culture in the 2008 campaign, it is worth taking a closer look at how culture may have been interpreted differently by English and French audiences.

Paul Nesbitt-Larking describes three definitions of the word culture. The first is related to what is considered "high culture," that is, the work produced by artists. A second definition, according to Nesbitt-Larking is "the general process of intellectual, spiritual, and artistic development of a people." He refers here to the definition of the expression: "Canadian culture." Finally, and more broadly, culture is a way of life specific to a group "in terms of those practices and artefacts through which they express their being." 277 Following is, once again, the controversial statement by Stephen Harper on culture in order to deconstruct its meaning by the two audiences.

"I think when ordinary working people come home, turn on the TV and see a gala of a bunch of people at, you know, a rich gala all subsidized by taxpayers claiming their subsidies aren't high enough, when they know those subsidies have actually

\footnotetext{
${ }^{277}$ Paul W. Nesbitt-Larking, Politics, Society and the Media: Canadian Perspectives (Peterborough, Ont: Broadview Press, 2001), 84.
} 
gone up -- I'm not sure that's somethıng that resonates with ordınary people"

Stephen Harper is suggesting the issue of arts and culture funding is of limited Interest and the purview of those defendıng "hıgh culture," whıch falls under the first definition explored by Nesbitt-Larkıng It is a notion of culture that as a campaign issue should not warrant concern by reasonable thınkıng Canadıans "I'm not sure that's somethıng that resonates with ordınary people"

This understanding of culture - and the reasonable right by a government to cut spendıng in this area - is put forward as accepted Ideology Nesbitt-Larkıng argues that Ideologies are manufactured belıefs and values manıpulated but founded from common "understandıngs of the world" They are put into play in order to assert power But in Canada, there are two separate "understandıngs of the world"

Nesbitt-Larkıng consıders culture and ideology as it is understood by medıa theorist Tony Bennett, who explaıned "the field of culture is a field of struggle, a sphere withın whıch dıfferent practıses of meanıng-makıng with dıfferent Ideologıcal consequences and effects ( ) vie with one another for domınance "278

In this way, each audience decoded Harper's statement differently The notion of culture as it refers to this particular federal polıcy had already been "encoded" for days in Quebec thanks to the viral spread of the "Culture en Peril" video, followed by assertions by the Bloc QuebecoIs, the NDP and the Liberal Party, and then further repeated by the Quebec medıa in a kınd of feedback loop The projected sıgnifıcance of

${ }^{278}$ Nesbitt-Larking, Politics 86 
culture in this context had been encoded in francophone Quebec to involve NesbittLarking's second and third definitions of culture. In this way, defenders of Quebec culture asserted that interference with funding of the arts now signified an interference with "the general process of intellectual, spiritual, and artistic development of a people." To interfere with this definition of culture is to impede the aspirations and way of life of French Quebec, and how they "express their being."

Le TJ sometimes reflected on this very issue, for example, in SRC reporter Guy Gendron's report on "Culture en Péril" appearing September 19 in which he included a clip of Prof. André Lafrance from the Communications department of the Université de Montréal:

(translation) "Is this a message about how the government cut money from culture, or that the federal government is filled with anglophones and they don't understand Quebec; here the dossier has changed, right?"

This became a powerful ideological tool for the Bloc Québécois and its leader Gilles Duceppe in asserting why Quebeckers should not vote for the Conservative leader. Consider more closely Duceppe's statement in a report the day following the protest concert:

"Quebec's visions and Stephen Harper's visions oppose each other. That's why in Quebec, the vast majority think that, we must not give Stephen Harper a blank cheque. We must keep him in close check."

A Quebec audience had pre-conceived understandings of the significance of culture in its struggle to survive as a nation, as already discussed in chapters three and 
four. Therefore, in the "struggle for dominant meanıngs," Duceppe had a clear advantage in presenting his argument to a Quebec audience.

Further, it was not unreasonable for Stephen Harper to assume his argument on the culture issue would resonate among many English-speaking Canadians, particularly rural voters - seen as a significant constituency for the Conservative party. In a survey commıssioned by the Calgary Sun, the pollster asked "Should the feds increase spending on arts and culture?" Eighty-six per cent of those surveyed said no. ${ }^{279}$ A National Post article during the election campaign asked popular talk show hosts in Manitoba, Saskatchewan and Alberta how their own listeners responded to the decision to cut funding to arts. The hosts reported listeners supported the Harper government decision. Dave Rutherford, host of a top rated radio show aired throughout Alberta, responded: "the people who listen to me and respond to my program are in full agreement with the attitude of the Prime Minister in this case." 280 Bill Tieleman, former communications director and political strategist for the NDP in British Columbia under Premier Glen Clark, explained Harper's target audience:

"These are the average, workaday Canadians in the suburbs, exurbs and rural regions -- those whose cultural experiences are more about TV's Survivor than the Stratford Festival. (...) It is elites versus the ordinary people." ${ }^{281}$

Virtually the only dissenting voice challenging what seemed an accepted ideology regarding "cultural elites" were English artists themselves. They fought back

\footnotetext{
${ }^{279}$ Kevın Lıbın, "Harper's arts cuts, a populıst move?" The Natıonal Post, September 27, 2008, accessed June 5, 2011, http //network nationalpost com/np/blogs/fullcomment/archive $/ 2008 / 09 / 27 / \mathrm{kevin}-l_{1 b}$ inharpels-arts-cuts-a-populist-move aspx

${ }^{280}$ Libın, "Harper's arts cuts."

${ }^{281}$ Libin, "Harper's arts cuts"
} 
usıng very different arguments compared to francophone groups, strugglıng from withın a different paradigm where culture for most Canadians is not connected to Canadian Identity In order to challenge the characterization of arts as the purview of elites, they made ratıonal economic arguments 1) that the arts as an industry contributes to Canadian wealth, 2) that artists are not elite or "rich," but struggle to survive, and 3) finally that Canadians benefit as they are committed consumers of Canadian production from film to books to music ${ }^{282}$ There was not a lot of discussion about the protection of a "Canadian culture" or an identity as a people ${ }^{283}$

A Tory strategist quoted anonymously in the Natıonal Post article said he delighted in watching the response from English artısts who held a media conference in the days following the Prime Mınıster's remarks

"It's so rich for them to be insultıng and complaınıng that they're not gettıng even more subsidy money than they already do, when average people are worried about economic uncertainty ( ) If I had my way, I'd have them on the air SIx hours a day"284

The problem for English artısts, however, was more about lack of coverage than too much coverage The largest event in English Canada took place September 25, and

\footnotetext{
782 James Bradshaw, Harper plays populist tune on arts cuts," Globe and Mall, September 11, 2008, accessed June 5, 2011, http//www theglobeandmail com/news/politics/article 708298 ece

${ }^{283}$ For a good sample of how English Canadian artists defended themselves from Harper's comment about "rich artists" see Margaret Atwood, "To be creative is, in fact Canadian," Globe and Mal September 24, 2008, accessed June 5, 2011, http //www theglobeandma1l com/news/politics/article712137 ece, also "Stephen Harper's use and abuse of culture," 101 Reasons not to vote for Stephen Harper, accessed June 5 , 2011, http //1001 easons ca/101/, also see Rob Benzies, 'Ordinary folks don't care about arts Harper," The Toronto Star, September 24, 2008, accessed June 5, 2011, http / www thestar com/FederalElection/article/504811

${ }^{284}$ Libin, "Harper's arts cuts"
} 
It did not make it into the line-up of The National that night ${ }^{285}$ It is perhaps significant to note that artists in English Canada are not held in the same regard as francophone artısts among Quebeckers Quebec artısts actıvely and openly partıcıpated, and contınue to partıcıpate in Quebec polıtıcs A member of the Radıo Canada natıonal election team, journalist Daniel Lessard, wrote about this in his politıcal blog during the campaign In a submission called "Les Artistes et Politıque," on September 22 he wrote (translation) "In Quebec, artısts were on the front lınes in the advancement of the sovereignty movement From Paulıne Julien and Doris Lussier to Paul Piche, their influence was significant in Quebec "286

The wide distribution of the YouTube video "Culture en Peril" can be credited to the enormous popularity of the artists featured in it, as well as the shared understandıng of its themes It included Quebec singer Michel Rivard, a member of the now disbanded group Beau Dommage, whıch enjoyed record-breakıng album sales during the 1970s The words of the song "La complaınte du phoque en Alaska," are well-known to Quebeckers, it is sung all together at concerts in a kind of anthem tribute to their shared cultural identity The idea that Rivard, his band, nor his song would be recognized by English bureaucrats, as depicted in the video, or that the song's essential meanıng (phoque - seal-misunderstood as $f--k$ ) would be denigrated through translation to English, resonated as a metaphor for the classic Quebec myth about the domınant language group, and its disregard for Quebec culture it plays on stereotypes and the deep-seated fear that the Englısh are intent on destroyıng Quebec culture

\footnotetext{
${ }^{285}$ The event was covered by other platforms and programs of the $\mathrm{CBC}$

${ }^{286}$ Daniel Lessard, 'Les Artistes et Politiques" Les Carnet, September 22, 2008, accessed June 11, 2011 , http //www radio-canada ca/nouvelles/carnets/2008/09/22/106240 shtml
} 
Because of its popularity in French, a subtitled translation subsequently appeared on YouTube, but its themes did not resonate as well with English audiences, and some Englısh artists were offended by its stereotypes of Englısh Canadıans ${ }^{287}$

Another aspect of Quebec dissent is the support from powerful players, including the premier Jean Charest supported artısts along with other members of the National Assembly from both sides of the aisle They opposed federal cultural policy, and argued for cultural money to be transferred to the Quebec government

\section{Treatment of the Bloc Quebecols}

As earlier discussed, there existed a quantitative difference between The Natıonal and Le Telejournal in their treatment of the Bloc Quebecois It's worth considering this difference qualitatively in order to assess how this affected the campaign narrative

On The National, other than the campaign launch day and the sımılar round-up reports appearing at the very end of the campaign, almost no stories focused exclusively on the Bloc Gilles Duceppe dıd appear from tıme to tıme in reports reactıng to Issues, but infrequently Even when discussing Quebec specifically, Duceppe often appeared only in visuals Consider agaın, the report by Rosemary Barton that appeared September 23 regardıng the artısts' protest concert in Montreal In that report, Barton

\footnotetext{
${ }^{297}$ Brendan Kelly, The Montreal Gazette arts critıc based in Montreal did an interesting critique of the video and its stereotypes of anglophones He wrote "This is an issue that artists across the country agree on and it is NOT a French English thing and to portray it as such is dishonest with gusts up to downright hystencal and anglophobic" See Brendan Kelly "What the phoquel Are you as offended by this clip as I am?" The Montreal Gazette September 27, 2008, accessed July 20, 2011, http //blogs montrealgazette com/2008/09/22/what-the phoque-are-you as-offended-by this clip as 1 am/
} 
used a clip from Harper, Dion and even Jack Layton, but none of Gilles Duceppe, who had the most to gain from the attack on culture in Quebec. Duceppe did appear in a visual following a clıp from Layton condemning the cuts to culture programs. When the voice-over stated: "Layton is not alone... Duceppe has been attacking Harper on the issue in a bıd to secure the nationalist vote," there appeared a visual of Layton shaking hands with Gilles Duceppe; Duceppe, in other words, had to share his spotlight. Also, the voice-over statement "...in a bid to secure the nationalist vote," implied that Quebeckers who support the party support its sovereigntist ambitıons, a notion that risks catering to a frequent misunderstandıng among Englısh Canadians about why Quebeckers support that party. ${ }^{288}$

However, since two thirds of Quebec seats went to the Bloc (for the third election in a row), while at the same time interest in sovereignty was at an all time low (below 35 per cent), a more nuanced understanding of Quebec voters' intention seemed to be consistently missing from the anglophone election news narrative.

Certainly, coverage of the Bloc has limited relevance for most English Canadian voters. However, since the party seemed to be so central to the telling of the Quebec story in this and other elections, and since Quebec had figured so significantly in

\footnotetext{
${ }^{298}$ To be clear, Rosemary Barton is perfectly bilıngual, attended College unıversitane de Saint-Bonıface and spent years covering the Natıonal Assembly for both Global Television as well as the CBC - she has a cleat understanding of the Quebec reality However, while Barton may have a nuanced understanding of the word 'nationalıst,' the popular understanding among Englısh Canadians mvolves the idea of sovereıgnty or political separation The word "nation" among Quebeckers refers to the collective "people of Quebec," and so in this way "nationalısm" means supportıng the people and not necessarly the independence of the nation A good example of this notion is the Quebec legislature and the library which are called respectıvely "L'Assemblée natıonale du Québec," and "Le Bıbhoteque et Archıves natıonales du Quebec"
} 
defining what kind of government Canadians got on election day, the lack of coverage could leave English viewers with at best a stunted understanding of the election story. At worst, since the limited coverage that did exist often appeared through a negative frame -- for example, using phrasing such as "...in a bid to secure the nationalist vote" or descriptors such as "the separatist Bloc Québécois" Canadians got a negative impression of the party and by extension, the Quebeckers who voted for them.

However, one of the impediments to covering the Bloc-according to the journalists interviewed for this thesis who work for English news organizations in Quebec - is the attitude toward the party from assignment desks in Toronto.

The National's Quebec correspondent in 2008 -- Nancy Wood -- has close to 25 years experience working as a journalist both at the National Assembly and Parliament Hill. Her credits include The Gazette, The Toronto Star and Macleans magazine before going to the CBC. During the 2008 election campaign she was assigned to the Bloc and in an interview for this thesis described what it was like to pitch stories involving the party:

"I think there's a veiled hostility toward the Bloc. There's the sovereignty issue of course, but they think (the Bloc) have always had an easy ride, and I think they felt Quebeckers weren't critical enough; there was something illogical about (Quebeckers voting for the party). ${ }^{289}$

Daniel L'Heureux, now retired, worked for Radio-Canada for more than three decades. Since 1984, L'Heureux worked as a correspondent in Ottawa, including the

${ }^{289}$ Nancy Wood, Interview, July 15, 2011. 
period when Lucien Bouchard walked out on Brian Mulroney's Conservative Party to

form the Bloc Québécois following the failure of the Meech Lake Accord constitutional

negotiations. L'Heureux said the Bloc always had a legitimacy problem among English

journalists.

"Even the most serious reporters questioned the right of Quebeckers to be elected who would challenge (national unity) and threaten to break up the country. In their minds, this was not a legitimate presence in Ottawa. The French reporter would never feel this way: 'You were elected, you pay taxes, you have the right to be there.' The English would hate to think about the idea that (the Bloc MPs) take a pension from the federal government or that they use public funds to promote their sovereigntist ideas." 290

On the other hand, the omnipresence of the Bloc in Quebec federal election reporting on Radio-Canada is equally criticized. Christian Bourque has been a Quebec pollster since the 1995 referendum, and the firm where he currently works, Léger Marketing, was cited by election observers in 2008 as the most accurate in polling of Quebec voters. ${ }^{291}$ Bourque said he felt "(the media) have a huge role to play to determine what is salient at a given point in time." He said the Bloc's sovereigntist vision may have only represented the minority, but they were "brilliant tacticians" at representing "le consensus Québécois;" a consensus manufactured by the Bloc. About the culture cuts, he said:

"So maybe there'll be fewer Quebec mimes walking around Paris, is that really a

\footnotetext{
${ }^{290}$ Daniel L'Heureux, Interview, July 17, 2011

${ }^{291}$ L. Ian MacDonald wrote in a Pollcy Options article that Léger came out "the clear winner in the pollıng sweepstakes," for calling the election result three days before election day. MacDonald, "A Missed Rendez-vous," 31. Chrıstıan Bourque durıng an interview saıd Léger Marketıng use larger populatıon samples and accounts for Quebec regional differences, where other pollsters tend to over sample the francophone nationalist vote in smaller samples as a portıon of Canada-wide surveys Christıan Bourque, Interview, July 20, 2011.
} 
problem? But it was impossible to say that after that consensus around the culture cuts was built up by Le Bloc Québécois."

The Quebec media may have been complicit in this, he said, because the Bloc

became a kind of default go-to in order to balance reports in election coverage:

"If (the media) do a story on the Liberals and you want someone to react to it, we know the Bloc will react immediately if it has any impact in Quebec, so the Bloc is always the other side. (...) so in a way they get half of the election coverage; they're always the counter to the Liberals, to the Conservatives, to the NDP. (They're) very accessible, very vocal and very well organized when it comes to French language media."

Nancy Wood said she noticed this phenomenon during the 2008 campaign:

"(Gilles Duceppe) would get much greater coverage, say, reacting to the Bush bailout package, but how relevant is his opinion? If you think about it logically, wouldn't it make more sense to have the Premier of Quebec, the man who's actually (...) in charge of our economy giving his opinion than the leader of the third or fourth party in Ottawa? So you know I would find that he would get a lot of coverage for things where he didn't have much real impact."

Christian Bourque says easy access to the Bloc on the culture cuts issue helped

develop the story as a central theme during the 2008 campaign. He said media troll for

stories that will resonate with audiences, and the 2008 campaign began with few of

those "sticky" issues. The media did not create the culture cuts, he said, they just

"throw the bait out" hoping someone will bite, and "if people get hooked the media play it more":

"(The media) can blow up something if it creates excitement in the campaign. (...) but I don't think the media coalesced with the Bloc on that issue. It was more the case that the Bloc fed the hungry giant and it continued over a few days." 
Daniel L'Heureux says the issue appealed most to the Bloc because it was related to Quebec identity:

"Because it's related to identity and "nous et les autres" and to get the unity of your group you need an enemy and if you can identify Harper as the enemy, the enemy of culture, the enemy of youths, that's what they're hoping for."

In this way the treatment of the Bloc Québécois created very different dynamics on The National and Le Téléjournal during the campaign. While the Bloc helped drive the culture story for French audiences, its absence on The National may have contributed to missing this campaign narrative for English audiences.

\section{The Conservative Party and the Message}

As already discussed, it would seem the media tended to hold "the fiddle for the politicians to play, rather than attempting to call the tune." ${ }^{292}$ If this is the case, one last look at the Conservative party sheet music may offer some insight at the dynamic that took place in the media in 2008. Michel Auger mentioned the Conservatives lack of political star candidates in the province. Because of the years shut out of Quebec following the Mulroney era, the party relied on the political machinery of the ADQ in many regions. The communications strategy was highly centralized, and only at the very end of the campaign did candidates in the Quebec City region fight back on their own without their leader against attacks by the Bloc Québécois, as demonstrated through the media conference in the final week.

\footnotetext{
${ }^{292}$ Soderlund et al, Media and Elections, 72.
} 
Unlike the 2006 campaign where the Conservatives made the first inroads into the province with a platform promotıng "open federalism," the 2008 platform offered few Quebec-centric items. ${ }^{293}$ Meanwhile, other platform items such as its get-tough-oncrime strategy toward young offenders and the culture cuts received very negative press in Quebec. Former Conservative speech-writer and columnist, L. Ian MacDonald said the party had few people in the war room to vet the platform and the strategy for Quebec audiences. One communications strategy involved a vehicle with a billboard following the Bloc campaign bus around suggesting the Bloc had been a complete waste of taxpayers' money over the years. MacDonald said it showed contempt for Quebec voters, and was quickly abandoned. MacDonald attended the media conference the day the Conservatives unveiled its young offenders' strategy on September 22. MacDonald said the platform seemed to be well received by the English media but:

“The French questions were all 'you're gonna send kids to prison?' and 'what about those culture cuts?' and I thought: 'uh oh... incoming...' and there were smart guys there who could see it coming, but in the war room they were completely witless. And only in the last week, with the crash in the stock market and Harper pounding the pavement in Quebec did they manage to save ten seats. They started (the election) hoping for thirty, but there was a point when they thought they'd only get five."294

It may be worth comparing this strategy to the approach of the NDP. The NDP credit their enormous success in the 2011 election $^{295}$ to the seeds planted in Quebec

\footnotetext{
293 Bélanger and Nadeau, "The Bloc," 156.

${ }^{294} \mathrm{~L}$ Ian MacDonald, Interview, August 11, 2011

${ }^{295}$ In the most successful election for the party ever, the NDP won a record 103 seats becoming the Official Opposition More incredible still, having never won more than a single seat (and only in two previous elections), in 2011 the party picked up 59 seats in Quebec, almost wiping out the Bloc Québecois The
} 
during the 2008 election campaign. Leader Jack Layton no longer wanted to be seen as 'the half' in the 'two-and-a-half' party system; ${ }^{296}$ he said he wanted to be Prime Minister. The communications director for the party, Marc-André Viau says Quebec was a central part of that strategy. For the first time, the party decentralized communications, set up an office in Montreal, and hired a Quebec ad firm to handle the Quebec message for 2008. The popular "Conservatueurs" 297 advertising campaign was not just perfectly timed but for the first time, grabbed up some of the space taken up by the Bloc on the issue of culture.

"Because we knew it was important to understand inside Quebec, we wanted to find the right message for Quebec. It is different. There's a different way of doing politics in Quebec. There's a different way to talk to people. The media is different. So if we use only a generic message and copy paste it, it's not going to work. So to spread our message it was important for us to decentralize and regionally organize our office in Montreal."

Viau suggests wedge politics, as practiced by the Conservatives in 2008 , was not

a good strategy for Quebec:

"In the rest of Canada it works better than it works in Quebec. I think it's easier to exploit wedge issues in Canada; it's Alberta versus Toronto, it's rural versus urban ridings. In Quebec you won't be able to exploit those to your advantage because Quebec sees itself (in a national context) as a block." 298

Quebec MPs dominate the NDP caucus "Official Votıng Results' $41^{\text {st }}$ General Election," Electıons Canada, accessed June 11, 2011

${ }^{296}$ Canada is considered to have a 'two and a half' party system, where historically two natıonal parties (the Liberals and the Conservatives) have been elected to form government, and a third (the NDP), while able to influence policy, never electing enough MPs to form government.

${ }^{297}$ Viau says the NDP for the first time competed with the Liberals and the Conservatives with a similar ad budget It hired a Quebec firm to undertake advertısing. The "Conservatueurs" campaign began as a typo by one of the ad men. Marc-André Viau, Inteview, August 12, 2011.

${ }^{298}$ Marc-André Viau, Interview, August 12, 2011. 
Following the 2008 election during the debate over the possibility of a Liberal led coalıtıon takıng over government, Harper seemed to employ wedge politıcs agaın He tried to demonize the effort because it involved a deal with the Bloc Quebecois By suggestıng the Liberals were in bed with 'separatısts' he alıenated many Quebeckers, since a plurality had supported that party for almost two decades, and even among those who did not, sovereignty is still seen as a legitımate optıon

Following the 2011 election campaign, the Conservatives were reduced to a handful of Quebec seats As described earlier in this thesis, the brokerage party system managed regional differences from withın the parties in order to help win majority governments The Conservatives have had mınımal representation withın the party from Quebec in order to do that Without being able to manage differences from withın, perhaps the party is left vulnerable to medıa scrutıny of their message shortcomings for Quebec audiences

On the other hand, the Conservatives stıll obtained a majority in 2011, suggestıng some vulnerabılıty for the future of the brokerage party system It's not clear what kınd of threat this poses for national unity Certaınly the medıa in 2008 didn't do much to bring Canadians closer together

\section{In General}

In general, the programs featured pronounced differences in story-tellıng durıng the election campaign of 2008 Much of the tıme, the line-ups diverged substantially with lead stories focused on different subjects When the two shows did deal with the 
same subjects, the story focuses diverged in important ways. While The National and Le Téléjournal diverged from each other, they had a lot in common with their samelanguage competitors in their respective markets. Both programs seemed more often than not, to follow the agendas of the politicians, and in Quebec, that included the Premier of Quebec and the Bloc leader. The Bloc became the default "other side" for many issues, giving it enormous power to drive the campaign narrative for French newsrooms while the Conservative Party faced a number of challenges with its Quebec campaign strategy.

It's fair to say at this point, few examples demonstrate the CBC and RadioCanada lived up to their mandate to foster "a shared national consciousness." 


\section{Chapter 7: Conclusion}

As mentioned previously in this thesis, election coverage at the public broadcaster is monitored for fairness and balance by outside researchers. The corporation has been routinely doing this exercise since $1993 .{ }^{299}$ Since 2004 , however, the job has been split between two research organizations: Erin Research based in the Toronto region for the $\mathrm{CBC}$, and the Universite de Laval's “Centre d'études sur les médias," based in Quebec City for SRC. Both came to the same conclusion for the 2008 campaign. The Centre d'étude sur les medias analyzed all Radio-Canada platforms and programs including Le Téléjournal:

(translation) "To conclude, we find that the journalists of Radio-Canada covered the federal election campaign with rigour and balance, conforming to the rules of their profession."

Erin Research made the same finding, adding a comment about the subjectivity

inherent in such an exercise.

"All in all, CBC coverage of the 2008 campaign appears to be fair and balanced. There are no absolute standards for what a broadcaster ought to do in campaign coverage; it is a matter of informed judgment. Past journalistic practice is probably as good a guide as any, and by this standard, $\mathrm{CBC}$ coverage was on course, consistent with the 5 election campaigns since 1993." ${ }^{301}$

The two research organizations, therefore, concluded the programs of the two services satisfied the rules to remain fair and balanced in the coverage of the 2008

\footnotetext{
${ }^{299}$ Confirmation from Pat Zulmov, Erin Research, e-mail August 19, 2011

300 "Analyse de la couverture de la campaıgne électorale fédérale 2008 par la Socıété Radı-Canada," 20, CBC/Radı-Canada, accessed August 7, 2011, http //www cbc radio-canada ca/annualmeetmg/Couvertueelections-federales-2008 pdf

301 "Balance in News Coverage of the 2008 Federal Election Campaign," Erın Research, 4, accessed August 7, 2011, http $/ /$ www ermresearch com/mages/cbc pdf
} 
election campaign. ${ }^{302}$ Still, this thesis clearly demonstrated two distinct election coverage narratives during the 2008 campaıgn. This analysis showed differences in the choice of stories, as well as differences in story focus on those occasions when both covered the same subject. Stories that led Le Téléjournal, sometimes did not appear on The National and vice versa. Stories that appeared high on The National line-up received treatment through copy lower down the line-up of Le Téléjournal and vice versa. The general themes appearing on The National included campaign gaffes, issues of leadership, and a focus on the economy. Le Téléjournal developed themes around culture, federal-provincial relations, and youth crime. The two programs diverged in how they framed certain ideas and issues including culture, treatment of the Bloc Québécois, and the significance of provıncial leaders. These differences follow many of the same distinctions consistently found in previous research as seen in chapter three.

These differences are not apparent through the analyses dealing with fairness and balance in political coverage undertaken separately by Erin Research and the Centre d'études sur les medias. As mentioned, the public broadcaster once had the same research company undertaking this job until 2004 , but the public broadcaster decided to separate the task. During an interview for this thesis, the President of the $\mathrm{CBC}$, Hubert Lacroix explained that because the two news environments and their markets are so

\footnotetext{
${ }^{302}$ As mentioned in chapter one, the rules of election coverage since the early 1990 s as part of CBC Journalistic Standards and Practices, states "Particular care must be given to information programs durnng election or referendum campaigns These series require close and meticulous attention to overall political balance. Quantitative checks are normally employed for guidance during election or referendum campargns Such quantitative checks must be supplemented by the exercise of qualitative judgments so that imbalance does not occur through the manipulation of events "CBC Journalistic Standards and Practices," CBC/Radıo-Canada, accessed November 22, 2008, http //www cbc radiocanada ca/docs/policies/journalistıc/ $\mathrm{xml} /$ policies asp
} 
dıfferent, "we thınk that by doing it that way we get the best possible research and that's more important than having something you can compare "303

The publıc broadcaster should be publıcly accountable for issues of journalistic professionalısm and balance examıned in the two reports, and as such this work is a valuable exercise This work measures some of the professional "journalıstıc creed" values assessed in chapter four However, as seen during that discussion, the "creed" values do little to explain the differences in content between the two services following the same campaign The separate reports measure journalistic rigour, not the mandate to foster a "national consciousness"

Yet, this part of the mandate had been a key goal from the inception of Canada's publıc broadcastıng as a natıon-buildıng project, and then reiterated in subsequent broadcastıng acts It is a mandate undertaken by states internatıonally Consider again the words of the first head of the $\mathrm{CBC}$ board of directors, Leonard Brockıngton

"If Canadian (broadcastıng) makes no lastıng contribution to a better understandıng between the so-called French Canadıan and the so-called Englısh Canadıan, between the East and the West, then we have faltered in our stewardshıp" 304

Unlike the commissioned studies on balance and fairness, this thesis' undertook a comparative analysis of the content produced by the two services reportıng on the federal election campaign - one of the few opportunities for national debate it found

\footnotetext{
${ }^{302}$ Hubert Lacroix, Interview, August 9, 2011

${ }^{204}$ Jones, 'Ethnic," 69
} 
through qualitative analysis clear differences in coverage, and more over, not a lot of content that helped viewers understand "the other."

Since Canadians pay for the public broadcaster, it's worth considering how members of the public feel about its coverage of the federal election - one of the broadcaster's primary democratic functions.

The French service ombudsman, Julie Miville-Dechêne in her annual report of 2008-2009 discussed the feedback from the public regarding Radio-Canada's 2008 election campaign coverage. Miville-Dechêne said she received 20 complaints from audience members saying Radio-Canada showed bias in its reporting against the Harper government. Nine complaints suggested the NDP received insufficient coverage. Five citizens felt the Bloc Québécois did not receive just coverage; among them, one person who said the Bloc should receive equal amounts of coverage as the other major parties. Miville-Dechêne made clear the complaints did not represent a poll, simply a report on the people who made the effort to contact her office. However, she gives several samples that reveal how some citizens viewed how issues had been dealt with. A number of statements involved the issue of culture. For example:

(translation) "The public broadcaster depends in large-part on public funds, and this explains the sensitivity around the protests of artists (...) The news service is no longer giving us neutral nor quality information." Michel $B$.

On the issue of the NDP coverage, one person wrote:

(translation) "Tonight you mentioned the Conservative rally which involved 500 people in Longueuil. Great. But meanwhile, we were twice that number almost a thousand - meeting at the Club Soda in Montreal to greet Jack Layton. And you passed over that event with total silence. Why?" Alexandre B. 
In the same annual report, the ombudsman included some of the findings of six citizen consultatıon committees which involved 30 members of the public put together to go over the 2008 election campaign coverage. The citızens, she reports, criticized the lack of diversity in the issues covered as well as the people chosen to discuss the issues. While they found the journalists competent, partıcularly in the "reality check" reports, they had negative comments as well. Here is an example of criticism against television:

(translation) "On the subject of the cuts to culture, (...) we get the distinct impression the journalists - who are the friends of members of the arts community in Montreal and elsewhere - followed the debate blow by blow (...) We expect more balance from our public broadcaster." ${ }^{305}$

The English language Ombudsman provided no such feedback publicly, although Kirk LaPoInte says similar committees have been assessing English coverage following elections, with reports of findings reviewed internally. ${ }^{306}$

While it is certainly problematic to rely on anonymous web comments to assess the true nature of Canadian views, they do offer some insight. What emerges reading many of the more than 1200 comments appearing on the $\mathrm{CBC}$ website the day after the election is a general misunderstanding among some English Canadians' about what happened in Quebec. Here's one example of a view familıar to many Canadians.

"The Bloc and those in Quebec who support them are nothing but parasites sucking up taxpayers' money to destroy the country. They bring no benefit to the rest of Canada." ${ }^{307}$

\footnotetext{
305 "Rapport annuelle 2008-2009," 7-10, Bureau de l'ombudsman Services Francais, accessed August 9 , 2011, http //blogues 1adı-canada ca/ombudsman/files/2010/11/Rapport_annucl 2008 $2009 \mathrm{pdf}$

${ }^{306}$ Confirmed by Kirk LaPointe, CBC ombudsman, e-mall August 16, 2011

307 "Harper 'very pleased' with stronger minority," CBC ca, accessed June 11, 2011, http //www cbc ca/news/canada/story/2008/10/15/elexn-wednesday html.
} 
While this sentiment is not shared by all Canadians, few would argue there is a general misunderstanding between Canada's two linguistic communities about the other's motivation when choosing a government they both have to live with after election day.

The election result in 2008 featured two distinct patterns of voting with support for the Conservatives generally on the rise in the rest of Canada, and in decline in Quebec. What role the public broadcaster has played and, perhaps more importantly, should play in fostering mutual understanding can only be assessed with a deeper understanding of the two solitudes at the Corporation.

The actual impact of the media on voter choice is a subject about which most researchers have found little conclusive evidence. This, as already mentioned, is not the focus of this research. However, the study of the media's role in "gate keeping" and "agenda setting," does attempt to understand the relationship between the media and its audience. Paul Nesbitt-Larking in his book Politics, Society and the Media: Canadian Perspectives, writes:

"The job of the news media in making the news is to transform a complex series of events into a news package the audience can understand. This means that the story must be placed within a frame of meaning familiar to the audience." ${ }^{308}$

These "frames of meaning" are clearly different for English and French audiences. The National and Le Téléjournal, in coverage of the 2008 federal election campaign, share 'frames of meaning' with their market competitors more than with each other.

\footnotetext{
${ }^{308}$ Paul Nesbitt-Larking, Politics, Society, and the Media: Canadian Perspectives, (Toronto: Broadview Press, 2001) 345
} 
These differences between the two are clearly not new as suggested in chapter three. Consider the findings of Arthur Siegel's research about the two services in 1977, and then again, ten years later by Jean de Bonville and Jacques Vermette, and then again, ten years after that, in 1997 by researchers Julie Fortier and Denis Monière. In all three studies, the French and English services featured different outputs. Again and again, this research showed Radio-Canada continued to be preoccupied with Quebec in its news coverage and few stories overlapped with the English service. In a comparison with TVA, Fortier and Monière found a growing similarity between SRC and its competitor:

(translation)"(...) placing more importance on proximity in order to compete in the battle for ratings and advertising (...) and so, SRC is now even further away from the objectives of the mandate of the public broadcaster. ${ }^{309}$

Fortier and Monière undertook their work at the end of the 1990s; a period when Radio-Canada began competing fiercely for ratings with TVA along with a recent competitor in the market: TQS. In 1984, Le Téléjournal attracted 689,000 viewers. By 1990 , ratings were up to 781,000 but since then viewership has been on an accelerating decline throughout the last decade. Today ratings for the program are at 294,000 viewers. ${ }^{310}$ TVA has also seen its viewership decline during this perıod, facıng the same issues challenging television news programming throughout North America - namely competition for audiences faced with more and more choice on satellite television, the Internet, etc. Still, TVA has over 800,000 viewers watching its 10 o'clock newscast Le

\footnotetext{
${ }^{309}$ Juhe Fortıer and Denis Monière, Radioscopıe de l'information telévisée au Canada, (Montreal· Les Presses de l'Université de Montréal, 2000), 114

${ }^{310}$ Source CBC Corporate Communications courtesy of BBM ratings
} 
TVA 22 heures $^{311}$ (The Natıonal has fewer! see table 4). Pollster Christian Bourque says one of the keys to TVA's success is its salience with local audiences. ${ }^{312}$ He says in terms of news coverage, it tends to avoid federal politıcs and in particular, airing English comments that require translation.

"So if someone only answers a question in English, it probably won't make it into their (report). You may see a visual (of the person) in the report, (otherwise) they feel it's bad TV to translate somebody on air. So that probably accounts for a difference in how the campaigns are covered." ${ }^{313}$

Retired veteran correspondent, Daniel L'Heureux said he notıced Radıo-Canada began getting more and more concerned about its main competitor, TVA, during the late 1990s when TVA moved its flagship news program from $11 \mathrm{pm}$ to $10 \mathrm{pm}$ to compete directly with Le Téléjournal. Once TVA's all-news specialty channel LCN came along to compete directly with RDI, Radio-Canada started looking over its shoulder a lot more, according to L'Heureux:

"So more and more Radio-Canada took into account TVA and of course, TVA is going for ratings and they avoid translation and even without translation, they know the federal scene is not that interesting. A minister will be talking about closing a nuclear plant in Ontario, and the story is far from their viewers and the translation only adds another barrier between their public and the subject itself." $^{314}$

\footnotetext{
${ }^{311}$ BBM ratings for the TVA newscast has been as high as 818 thousand, one of the highest rated regional news programs in North Amenca Philıppe Meilleur, "Cote d'écoute TVA deviance son ses concurrants," Le Journal de Montréal January 1, 2008, accessed July 6, 201 1, http //fr canoe ca/diveitissement/telemedıas/nouvelles/2008/01/14/4771887-jdm.html

${ }^{312}$ Quebecor, owner of TVA, is a frequent clıent of Léger Marketıng, as are most medıa outlets, includıng $\mathrm{SRC}$

${ }_{313}$ Christian Bourque, Interview, July 20, 2011

314 Daniel L'Heureux, Interview, July 20, 2011.
} 
This highly competitive environment puts the mandate to foster "national consciousness" often at odds with makıng sure Radio-Canada remains salıent for viewers exposed to private competition.

Table 4: Ratıngs

\begin{tabular}{|c|c|c|}
\hline Program & $\begin{array}{l}\text { Ratıngs (BBM) } 1990 \\
\text { (among viewers over } 2 \text { yrs old and over) }\end{array}$ & $\begin{array}{l}\text { Ratıngs (BBM) } 2010 \\
\text { (among viewers over } 2 \text { yrs old and over) }\end{array}$ \\
\hline Le Téléjournal & 781,000 & 294,000 \\
\hline Le TVA $22 \mathrm{hr}$ & & $818,000^{* *}$ \\
\hline The National & $1,420,000$ & 641,000 \\
\hline CTV National News & & $1,000,000^{* * *}$ \\
\hline
\end{tabular}

The National also faces declining audiences and attracts sometimes as little as half the audience of the number one newscast among English Canadians, CTV National News. ${ }^{315}$ Consider, however, that The National and CTV National News ${ }^{316}$ combined have on average fewer than 2 million viewers or a little over 7 per cent of the population excluding Quebec on any given evening. ${ }^{317}$ The combined 1 million viewers of Le Téléjournal and Le TVA 22 heures suggest the two programs attract 13 per cent of

\footnotetext{
${ }^{315}$ In October 2009, television critic Alex Strachan suggested CTV National News averages 1 million viewers a night He writes The National dips as low as 500 thousand viewers some evenings, under a new BBM rating system, with CTV National News getting up to 15 million on some nights He blames the new BBM measuring for CBC's poor showing, because it monitors audiences throughout the program, and then averages the audience per minute He suggests The National, as an hour long progi am will measure lower audiences than the half hour CTV program. Alex Strachan, "News Ratıngs," TV Guys Gurde to Good TV, accessed July 25, 2011 , http //communities canada com/shareit/blogs/tvguy/archive/2009/10/07/newsratıngs-scole-1t-ctv-lloyd-1 oberston- 1 -cbc-peter-mansbildge-0-under-new-ratings-measulementsystem aspx

$\frac{5 y}{316}$ Global National, the third network, does not go on air during primetime and is not counted here.

317 "Canada's population clock," Statistics Canada, accessed July 25, 2011 , http //www statcan gc ca/1ggl/pop-ca-eng htm, Canada's population on that day was 345 millon people The researcher subtracted 79 million (the population of Quebec) to compensate for the Quebec market.
} 
the Quebec population. ${ }^{318}$ As well, according to the 2010 CRTC Monitoring Report, "news and analysıs" represents 17 per cent of total weekly viewing time among Englısh Canadıans, but 32.8 per cent among French-speakıng Canadıans, almost twice the rate. 319 This suggests that news and current affairs seem to have a larger impact on Frenchspeaking Canadians compared to English-speakers. Radio-Canada programmıng generally, as outlıned in chapter three, has been more successful than the English service in satisfyıng the public broadcaster's missıon to deliver distınctıvely Canadıan programs to audiences. It also suggests Quebeckers are more engaged in public debate than English Canadians.

Although Canadians still prefer Canadian news over foreıgn news, ${ }^{320}$ Englısh television generally faces a much larger problem attracting audiences competing both with the private sector, as well as same-language programmıng from the U.S, as discussed in chapter three. This has been the challenge facing the public broadcaster since its inception.

However, at some point, could ratings get so low they render the $\mathrm{CBC}$ irrelevant to Canadıans? The former president and CEO, Robert Rabinovitch laıd out the problem

\footnotetext{
318 "Quebec's population clock," Statistics Canada, accessed July 25, 2011, http //wwu statcan gc ca/1gg1/pop-qc-eng htm Quebec's population on that day was 79 million people Consider here that this calculation does not consider francophones outside Quebec

${ }^{319}$ Meanwhile, drama and comedy represent $431 \%$ of Englısh Canadian viewing hours where 213 per cent 1s Canadian content Francophones consume 37 7\% Canadian content in this category "Communications Monitoring Report 2010," CRTC, 78, accessed May 18, 2011, http //www crtc gc ca/eng/publications/rcports/policymonitorng/2010/cmu2010 pdf

${ }^{320}$ According to the broadcast monitoring report undertaken by the CRTC, news and analysis programming consumed by English audiences is 95\% Canadian, with Francophones consuming 99 5\% Canadian content Compare that to drama and comedy where just $215 \%$ is Canadian content among English audiences and $32 \%$ is Canadian among French audiences Consıder as well that drama and comedy represent $431 \%$ of Enghish Canadian viewing hours (37 7\% among Francophones) where news and analysis represents $171 \%$ (32 8\% among Francophones) "Communcations Monitonng Report 2010," CRTC, 78, accessed May 18, 2011, http//www crtc gc ca/eng/publications/reports/policymonitoring $/ 2010 / \mathrm{cmr} 2010 \mathrm{pdf}$
} 
before the Standing Committee on Canadian Heritage in 2007, durıng a review of the mandate one year before the 2008 campaign

"Of course, no matter how compellıng our programs, we cannot succeed if audiences do not watch or listen to them. Audience size is not everythıng, but one cannot have a public broadcaster without a public. (Rabınovitch's emphasis) If too few people are watching, or listenıng, we are irrelevant. (...) And, if we are Irrelevant, why should Canadians contınue to invest in public broadcastıng?"321

His pitch to the committee for stable long-term fundıng for the public

broadcaster included a proposal for a new contract with Canadıans "to ensure that

publıc broadcastıng provides the services Canadians want in the future "

"( ) the public broadcaster can be seen as a vehicle for cultural identity and social cohesion it is not easy to offset fragmentation and embrace diversity at the same tıme. (...) A public broadcaster can create community-buildıng spaces that serve as a buffer against fragmentatıon. These same spaces can also facilitate interaction and dialogue among different communities locally, regionally, nationally, and internationally." ${ }^{322}$

This "Interaction and dialogue" was not always evident across the space that divides the two solitudes in the coverage of the 2008 campaign. The challenges rub up against the mandate. As discussed in chapter one, the mandate is part of the state's effort to exert "technological nationalism" but tensions from both the private sector and Quebec natıonalısm, as just described, have shaped the kınd of publıc broadcaster Canadians experıence today. This thesıs has shown those tensıons at work, manıfested In the coverage dynamic that unfolded before Englısh- and French-speakıng audiences.

\footnotetext{
${ }^{321}$ Robert Rabınovitch, "Openıng remarks for Mr Robert Rabınovitch, president and CEO of CBC/RadıoCanada for CBC's appearance before the Standing Committee on Canadian Heritage," CBC Corporate, November 27, 2007, accessed July 22, 2011, http //www cbc 1adio-canada ca/speeches/20071127 shtml 322 Robert Rabinovitch, "Public Broadcasting in Canada Time for a New Approach Submission to the Standing Committee on Canadian Heritage," presented by Robert Rabinovitch to the Standing Committee March 22, 2007, accessed July 22, 2011, http //www cbc radio-canada ca/submissions/pdf/Mandate pdf
} 
That's not to say the mandate has not had some influence over programmıng.

The Fortıer and Monıère study, for instance also found that while SRC is more like its private competitors than the $\mathrm{CBC}$, its coverage of Canada outside Quebec is much better than the private broadcasters. The English service has also done a better job, the researchers conclude, at covering Quebec issues compared to its private industry counterparts. $^{323}$

Today Radio-Canada and the CBC continue to have a reputation for more comprehensive coverage of national and international news than their private competitors. Erın Research, for instance found the CBC referred to Gilles Duceppe, the leader of the Bloc Québécois, twice as much as CTV. ${ }^{324}$ The analysis undertaken by the Centre d'études sur les médias found a similar difference between Radio-Canada and TVA. For example, TVA included the NDP in 7 per cent of statements, according to the group's research, compared to Radio-Canada at 15 per cent. The researchers concluded Radio-Canada's mandate as a national broadcaster explains the differences in coverage:

(translation) "Radio-Canada is the only pan-Canadian French language media organization. The mandate is to serve all francophones across Canada. (...) Radio-Canada has to take into account the entire territory served even though the majority of its public is in Quebec. (...) The difference between the practices of Radio-Canada and those of TVA or the large Quebec dallies concerning coverage given to each of the parties does not necessarily translate as a problem. This is explained by taking into account the very particular mandate of the public service." 325

\footnotetext{
${ }^{323}$ Fortıer and Monière, Radıoscopie, 118

324 "Balance in News Coverage," 14 In measuring the proportion of statements with references to the party leaders, Duceppe received 4 per cent of coverage on CBC versus 2 per cent on CTV, both very low.

However, in a measurement of positive and negative statements about each party, the total number of statements on CTV about the Bloc was so low, it was not measurable

325 "Analyse de la couverture," 6
} 
Christian Bourque says the mandate does not necessarily put the corporation at a disadvantage It has developed a niche attractıng a particular audience, in this way, standing out from its competition which has a positive impact on federal election campaign coverage

"If it wasn't for the public broadcaster, our elections would be much more regionalıst But If Radıo-Canada did not cover Quebec, it wouldn't have the ratıngs As a private broadcaster why (care) what happens in Saskatchewan cause it doesn't matter to viewers Still there's an audience for that, and that's SRC -- same in the rest of Canada" 326

One good example of this commitment to natıonal coverage by Radıo Canada durıng the 2008 campaign was the presence of SRC correspondents on the leaders' tours TVA saved its money and jumped onto the tours only when the leaders made their way through Quebec, otherwise, TVA relied on pool feeds for coverage of the leaders The financial and personnel commitment by Radio-Canada translated into reports covering Issues outsıde Quebec, though these stories did not often play very high in the campaign news line-ups Radıo-Canada also has a presence from its reporters stationed throughout the rest of Canada where correspondents provided ridıng and regional profiles during the 2008 federal campaign ${ }^{327}$

Meanwhile, the "At Issue" panel on The Natıonal with the regular contribution of Chantal Hebert, has been frequently cited as a valuable forum for Canadians wantıng some insight into how the federal campaign is playıng out in Quebec

\footnotetext{
${ }^{326}$ Christian Bourque, Interview, July 25, 2011

ग7 There were, however, the usual complaints to the Ombudsman of Radio Canada about the poor coverage of francophone communities outsıde Quebec during federal election campaigns Daniel L'Heureux, Interview, July 26, 2011
} 
But was it enough to fulfill the challenge of the mandate? Certaınly, these efforts dıd not prevent the very different campaign narratıves that appeared on Le Telejournal and The National As mentioned, while it is impossible to know what Impact coverage had on how Canadians voted the election result can be viewed as further entrenchment of the two solitudes among voters in Quebec and the rest of Canada In this context, it's hard to see how the public broadcaster did much to promote a "shared national consciousness" Moreover, it would seem not much had changed in 2008 in terms of the public broadcaster actıng as a social integrator compared to even the most divisive periods of national debate

Consider as well, that the Conservatıves won a larger minority government in 2008 and then a majority in 2011 despite a communıcatıons strategy that seemed to enhance regional cleavage rather than broker differences between Canada's two lınguistic communities What will be the role of the public broadcaster in bringing Canadians together - particularly if election coverage contınues to allow the politicians to "hold the fiddle," as found so far? The risks are considerable, accordıng to some

Fred Fletcher, in consıderıng the ımpact of globalızatıon on Canada's dual medıa system, writes that Canadians and partıcularly polıtıcıans have been preoccupied with the need for public spaces to debate national issues (consider Robert Rabınovitch's pitch to the Standing Committee on Canadian Heritage in 2007 for a CBC that creates spaces that "facilitate interaction and dialogue") Yet, some are not optımistıc about how well the current dual system in publıc broadcastıng serves that purpose Media scholar Paul Nesbıtt-Larkıng suggests "We are a state whose natıonal system of publıc broadcastıng 
has been contributıng to its oblivion "328 The assumption discussed in chapter two, is that stable democracies require that citizens share a system of values and beliefs "so that the dispute resolution mechanısms of the political system are accepted as legitımate and a common vocabulary ( ) can be employed in public debate "329 Without a common sense of belongıng, Canadian researcher Greg Marc Neılsen warns "the more widespread the apathy concernıng a sense of belongıng to a country, the less citizens are willing to partıcıpate in the democratıc process and the greater the risks to that country of social disintegration "330

\section{Fletcher writes}

"The space for debate of a common future seems to be contractıng and the common vocabulary of historical precedents remains limited or divisive The gulf in news coverage of critical issues reduces the basis for resolution "331

With audience fragmentation in the globalized communicatıons system, creatıng those spaces for debate will likely get more difficult

In Canada, the state's effort to exert some kınd of "technological natıonalısm" has been met with tensıons leadıng to compromıses that are sometımes complementary, and often contradictory Consider the mandate to foster a "national consciousness" It has endured while at the same tıme - whether by accident or through deliberate polıcy - the publıc broadcaster developed and supported two separate consciousnesses through two separate networks it has been called in this thesıs "the paradox of the mandate," however, as Marc Raboy suggests, this policy has been "part of a political strategy to preserve the coherence of the Canadian state"

\footnotetext{
${ }^{39}$ Nesbitt-Larking, Politics Soctetv and the Media 64

${ }^{79}$ Fletcher, Media and Political Identity,' 362

30 Nesbitt-Larking, Politics Societv and the Media 65

331 Fletcher, "Media and Political Identıty, 366
} 
Canadian philosopher Charles Taylor suggests our federation's success has

depended more on the accommodation of two solitudes than efforts to impose national unity:

"(...) the combination of an unresolved national identity as Canadians and the strength of our historical regional societies make it virtually mandatory for us to practise a more decentralized style of government than other comparable federations." ${ }^{332}$

Canada's accommodation strategy has been an evolving project. One gauge of

its success is the referendum results on Quebec sovereignty which seem to suggest the majority of Quebeckers have so far opted to continue their relationship with Canada.

There seems to be a preference for a kind of non-state seeking nationalism described by political scientist Michael Keating, where people within a state exert their aspirations while enjoying the rights of their citizenship to the state. ${ }^{333}$

Radio-Canada has been one of the vehicles for exerting nationalist aspirations.

Radio-Canada has given French Quebeckers an opportunity to seek out those aspirations within the state of Canada, rather than seek a different arrangement through - for example - separation. Perhaps, as Raboy argues it's time to move from a broadcasting policy that promotes national identity and toward one that promotes "democratic community development and national, regional, and local public spaces."

"As Canada searches for a place in the sea of global culture, its linguistic duality is one of the most unmistakeable, irreducible forms of Canadian distinctiveness.

\footnotetext{
${ }^{332}$ Charles Taylor, "Alternative Futures," in Reconcling the Solitudes, eds Charles Taylor and Guy Laforest (Montreal· McGill-Queens University Press, 1993), 111.

${ }^{333}$ Michael Keatıng. "Stateless nation-bu1dıng Quebec Catalonia and Scotland in the changing state system." Natıons and Nationalism 3(4), 1997, 689-717.
} 
The challenge remains to try to find an institutional arrangement that turns this into a source of strength." 334

Rather than the state using public broadcasting to exert national unity or

identity, Raboy submits, the public broadcaster could contribute to holding civil society

together by creating spaces where "social antagonisms can be explored and worked out, not cater to accentuating difference $(\ldots)^{\prime 335}$

After all, despite this dual system, Canada has continued to thrive and has consistently chosen peace and stability over conflict and separation. Canadian communications theorist Richard Collins suggests this raises questions about assumptions that the current situation is "unsustainable and dangerous."

"The continued existence of Canada as a sovereign state, despite having little television programming shared by the two national communities (...) suggests that the nationalist axiom that political sovereignty and stability depend on cultural and communications sovereignty is misconceived." 336

Greg Marc Neilsen suggests, "it is, perhaps, not the deeds, but rather the narratives, that are missing. The two media solitudes may have helped to inhibit the development of such narratives." ${ }^{337}$ This analysis of the 2008 campaign coverage illustrates the public broadcaster continues to fall short of its mandate to bring Canadians together during national debates.

\footnotetext{
${ }^{334}$ Marc Raboy, "Linguistıc dualsty in broadcasting polıcy: A microcosm of Canada's constıtutional polıtıcs," in Seeing ourselves Media power and policy in Canada, eds H. Holmes and D. Taras, (Toronto: Harcourt Brace, 1996) 169

${ }^{335}$ Marc Raboy, "The World Situation of Public Seivice Broadcastıng. Overview and Analysis," in Public Service Broadcasting · Cultural and Educational Dimensions, (Paris·1997), 19-56.

${ }^{376}$ Fletcher, "Media and Political Identity," 363.

${ }^{337}$ Fletcher, "Media and Polıtical Identıty," 372.
} 
Certainly one of the solutions over the years has been to increase shared programming. During the 1990 s, as political tensions in Canada rose, the public broadcaster invested new money to boost bi-cultural programmıng, among them, the Canada. A People's History series. However projects of that nature dried up by the end of that decade and since then, budgets for the $C B C$ have become less stable.

CBC presıdent Hubert Lacroix says efforts for increased bı-cultural exchanges are part of a five-year plan to 2015 . The plan had to be delayed for two years because of budget cuts but he reports they're on track agaın

"It's a tough challenge but one that we want to tackle. This is our mandate (...) We're not perfect, but there are things in the plan to make us more integrated, closer, partly because of resources, as well, French and Englısh will be workıng together more and more." 338

The plan includes cross cultural programs and bi-cultural documentaries in both languages. But the $\mathrm{CBC}$ - as already mentıoned - is vulnerable to the annual federal budget process. On a much smaller scale, newsrooms have initiated bi-cultural projects by creatively reallocatıng resources. Durıng the 2008 campaign, for instance, RadioCanada's radıo service and CBC Radıo initıated an exchange of journalists to appear on each services' radıo programs. The Centre d'etudes applauded and encouraged this kınd of effort in its report.

Lacroıx says "we have a role to play in helpıng Canadıans understand each other" and yet "beıng different does not mean you're not deliverıng news in the right way"

\footnotetext{
${ }^{338}$ Hubert Lacroix, Interview, August 9, 2011
} 
The mandate itself may soon be up for renewal Hubert Lacroix says he supports updatıng the mandate, it has been more than 20 years since that exercise took place Keep in mind, however, that any debate over the mandate is fraught with potential conflict since it inevitably involves two clashıng notıons of national identity Marcel Masse, the federal Mınıster responsıble for the exercise in 1991, was accused of panderıng to separatısts when he announced the mandate would change from a requirement to foster "national unity" to "national consciousness" 339 However, enough Issues have been rassed in this thesis questioning whether the mandate is appropriate in the current context Perhaps a renewal is worth the risks if it can lead to bringing Canadıans closer together than durıng the federal electıon of 2008

\footnotetext{
${ }^{39}$ Marc Raboy, Missed Opportuntties The Story of Canada s Broadcasting Policv (Montreal McGıll Queens Unıversity Press, 1990)
} 


\section{$\underline{\text { Bibliography }}$}

\section{Books/Journals/Reports/Research}

Auger, Michel. "Le Québec du statu quo." Policy Options. (November 2008): 31-34. Accessed July 20, 2011, http://www.irpp.org/po/archive/nov08/auger.pdf

Anderson, Benedict. Imagined Communities. London: Verso, 2006.

Australian Broadcasting Corporation. "Australian Broadcasting Corporation Act 1983." Accessed June 5, 2011. http:/www.comlaw.gov.au/Details/C2008C00174.

Bélanger, Éric, and Richard Nadcau. "The Bloc Québécois: Victory by Default." In The Canadian Federal Election of 2008, edited by Jon H. Pammett and Christopher Dornan, 136-161. Toronto: Dundurn Press, 2009.

Canada, Royal Commission on Broadcasting, "Report." Ottawa, The King's Printer, 1929.

Canada, Standing Senate Committee on Transport and Communications. "Interim Report on the Canadian News Media." 2004. Accessed Oct 27, 2008. www.parl.gc.ca/37/3/parlbus/commbus/senate/com-e/tran-e/rep-e/01 apr04-e.pdf

-------. "Final Report on the Canadian News Media (2 volumes)." Ottawa: Parliament of Canada, 2006. Accessed October 27, 2007. www.parl.gc.ca/39/1/parlbus/commbus/scnate/Com-c/TRAN-E/repe/repfinjun06voll-e.htm

Carty, Roland Kenneth. "The Politics of Tecumseh Corners: Canadian Political Parties as Franchise Organizations." Presidential address to the Canadian Political Science Association, Toronto, 2002.

CBC/Radio-Canada, Annual Report 2006-2007, Spring 2008. Accessed Oct 28, 2008. http://cbc.radio-canada.ca/annualreports/2006-2007/pdf/AR0607 e.pdf

------. Journalistic Standards and Practices, 2006. Accessed Oct 30, 2008. http://www.cbc.radio-canada.ca/accountability/journalistic/index.shtml.

-...--. "Program Policies - CBC/Radio-Canada Mandate." Accessed November 12, 2008. http://www.cbc.radio-canada.ca/docs/policies/program/mandate.shtml.

Centre d'études sur les medias, Le. "Analyse de la couverture de la campaigne électorale fédérale 2008 par la Société Radio-Canada." Quebec City: Université de Laval, 2009. Accessed August 7, 2011, http:/www.cbc.radiocanada.ca/annualmeeting/Couverture-elections-federales-2008.pdf 
Collins, Richard C. Culture, Communication, and National Unity: The Case of Canadian Television. Toronto: University of Toronto Press, 1990.

Cooper, Barry and Lydia Miljan. Hidden Agendas: How Journalists Influence the News. Vancouver: UBC Press, 2003.

Conway, Kyle R. "Everyone Says No: Canadian Public Service Broadcasting and the Failure of Translation During Canada's Constitutional Crisis." PhD diss., University of Wisconsin-Madison, 2008.

CRTC. Broadcast Monitoring Report. 2007. Accessed October 27, 2007. www.crtc.gc.ca/eng/publications/reports/PolicyMonitoring/2007/bpmr2007.pdf

Communications Monitoring Report. 2010. Accessed May 18, 2011. http://www.crtc.gc.ca/eng/publications/reports/policymonitoring/2010/cmr2010.p df

De Bonville, Jean and Jacques Vermette. "Television et unité nationale: la couverture l'actualité canadienne a Radio-Canada, 1977 et 1987." Canadian Journal of Political Science (December 1994): 699-716.

Deutsch, Karl. Nationalism and Social Communication: An Inquiry into the Foundations of Nationality. Cambridge: Massachusetts Institute of Technology, 1966.

Drijvers, Jan. "Community Broadcasting: A Manifesto for the Media Policy of Small European Countries." Media Culture and Society 14, no. 2: 193-201.

Elcctions Canada. "Official Voting Results: $39^{\text {th }}$ General Election.” Accessed June 16, 2011. http://www.elections.ca/scripts/OVR2006/default.html

. "Official Voting Results: 40th General Election 2008." Accessed June 11, 2011. http:/www.elections.ca/scripts/OVR2008/default.html.

-.------. “Official Voting Results: 41 ${ }^{\text {st }}$ General Election.” Accessed June 11, 2011. http://www.elections.ca/scripts/OVR2011/default.html.

Ellis, Faron and Peter Woolstencroft. "Stephen Harper and the Conservatives Campaign on their Record." In The Canadian Federal Election of 2008, edited by Jon H. Pammett and Christopher Dornan, 16-62. Toronto: Dundurn Press, 2009).

Erin Research. "Balance in News Coverage of the 2008 Federal Election Campaign." Accessed August 7, 2011. http://www.erinresearch.com/images/cbc.pdf.

Fletcher, Frederick J. "Media and political identity: Canada and Quebec in the era of globalization." Canadian Journal of Communication. 23, no. 3, (Summer 1998): 359-380. 
Fortier, Julie and Denis Monière. Radioscopie de l'information télévisée au Canada. Montrcal: Les Presses de l'Université de Montréal, 2000.

Gans, Chaim. The Limits of Nationalism. Cambridge: Cambridge University Press, 2003.

Gellner, Ernest. Nations and Nationalism. Oxford: Basil Blackwell, 1983.

Hazel, Kathryn-Jane. "The Media and Nationalism in Quebec: a complex relationship." Journalism Studies. 2, no.1 (2001): 93-107.

Hébert, Chantal. French Kiss: Stephen Harper's Blind Date with Quebec. Toronto: Alfred A. Knopf Canada, 2007.

Jackson, John D. and Paul Millan. "English language radio drama, A comparison of regional production units." Canadian Journal of Communications 15, no 1.

Jones, Esyllt Wynne. "Ethnic Nationalism in Quebec and Wales: The Case of Public Broadcasting Conflict." MA thesis, McGill University, 1988. Accessed June 5, 2011. http://digitool.library.mcgill.ca:8881/R/? func=dbin-jumpfull\&object id $=618588$.

Keating, Michael. "Stateless nation-building: Quebec Catalonia and Scotland in the changing state system." Nations and Nationalism 3(4), 1997: 689-717.

Kent, Tom. Royal Commission on Newspapers. Ottawa: Parliament of Canada, 1981.

Klingermann, H.D., Richard Hofferbert, and Ian Budge. Parties, Policies and Democracy. Boulder: Westview Press, 1994.

Kozolanka, Kirsten. "The Sponsorship Scandal as Communication: The Rise of Politicized and Strategic Communications in the Federal Government." Canadian Journal of Communication, 31, no 2, (2006): 343-366.

Kwavnick, David ed. The Tremblay Report: Report of the Royal Commission of Inquiry on Constitutional Problems. Toronto: McClelland and Stewart Ltd, 1973.

Lacroix, Hubert. "Notes pour une allocution de Hubert T. Lacroix, président-directeur general de CBC/Radio-Canada." Speech during appearance before the Heritage Parliamentary Committee. May 1, 2008. Accessed October 28, 2008. http://cbc.radio canada.ca/discours/20080501.shtml

MacDonald, L Ian. “A Missed Rendezvous with a Majority." Policy Options. (November 2008): 24-31. Accessed July 20, 2011. http://www.irpp.org/po/archive/nov08/macdonald2.pdf

McRoberts, Kenneth. Quebec: Social Change and Political Crisis, $3^{\text {rd }}$ Ed. Toronto: McClelland \& Stewart Inc., 1988. 
Mendelsohn, Matthew Jay. "Television's persuasive effects: The priming and framing of leadership in the 1988 Canadian election." PhD diss, Ecole Polytechnique, 1994.

Miville-Dechêne, Julie. "Allocution de Julie Miville-Dechêne, ombudsman des Services français" Speech before the $40^{\text {th }}$ sitting of l'Union internationale de la presse francophone." October 16, 2008. Accessed October 28, 2008. http://cbc.radio-canada.ca/discours/20081016.shtml

------. "Rapport annuelle: 2008-2009," Spring 2009. Montreal: Bureau de l'ombudsman Services Francais. Accessed August 9, 2011. http://blogues.radiocanada.ca/ombudsman/files/2010/11/Rapport annuel 2008_2 009.pdf.

Nadeau, Johanne. "La représentation sociopolitique et culturelle de la société canadienne véhiculée par les nouvelles technologies: Une analyse de Radio-Canada et son influence sur l'identité nationale." MA thesis, University of Alberta, 2007.

Nesbitt-Larking, Paul W. Politics, Society and the Media: Canadian Perspectives. Peterborough, Ont: Broadview Press, 2001.

New Zealand Government. "Broadcasting policy in New Zealand." Accessed July 25, 2011. http://www.med.govt.nz/upload/12863/bpinnz.pdf;

Nielsen, Greg Marc. Le Canada de Radio Canada, Sociologie, critique, et dialogisme culture. Toronto: Editions de Grief, 1994.

Raboy, Marc. "Linguistic duality in broadcasting policy: A microcosm of Canada's Constitutional politics." In Seeing ourselves: Media power and policy in Canada, edited by H. Holmes and D. Taras. Toronto: Harcourt Brace, 1996.

------. "Media, Nationalism and Identity in Canada and Quebec." Res Publica 2 (1997): 316-323.

Missed Opportunities: The Story of Canada's Broadcasting Policy. Montreal: McGill Queens University Press, 1990.

"The Role of the Public in Broadcasting Policy-making and Regulation: Lesson for Europe from Canada." European Journal of Communication 9 no.1 (1994): $5-23$

------. "The World Situation of Public Service Broadcasting: Overview and Analysis." Paper presented to the Round Table on the cultural and educational functions of public service broadcasting, UNESCO, 1997.

Radio-Canada/Commercial Services. Portrait of a National Public Broadcaster. 2008. http://publicite.radio-canada.ca/en/marketing/Radio-Canada_2008_english.pdf

Pritchard, David, Paul R. Brewer and Florian Sauvageau. "Changes in Canadian 
Journalists' Vicws about the Social and Political Roles of the News Media: A Pancl Study, 1996-2003." Canadian Journal of Political Science 38, no. 2, (June -July 2005): 287-306.

Rabinovitch, Robert. "Opening remarks for Mr. Robert Rabinovitch, president and CEO of CBC/Radio-Canada for CBC's appearance before the Standing Committee on Canadian Heritage." CBC-Radio Canada Corporate, November 27, 2007. Accessed July 22, 2011. http://www.cbc.radio-canada.ca/speeches/20071127.shtml.

-------. "Public Broadcasting in Canada: Time for a New Approach: Submission to the Standing Committee on Canadian Heritage." Presented by Robert Rabinovitch to the Standing Committee, March 22, 2007. Accessed July 22, 2011.

http:/www.cbc.radio-canada.ca/submissions/pdf/Mandatc.pdf.

Robinson, Gertrude J. Constructing the Quebec Referendum: French and English Media Voices. Toronto: University of Toronto Press, 1998.

Schutz, Alfred. "On multiple realities." In Collected Papers The Problem of Social Realities, edited by Alfred Schutz, and Herman Leo van Breda. The Hague: Nijhoff, 1962.

Siegel, Arthur. A Content Analysis: The Canadian Broadcasting Corporation: Similarities and Differences of French and English News. Background Research Paper, Committee of Inquiry into the National Broadcasting Service, CRTC, 1977.

-----. Politics and the Media in Canada, $2^{\text {nd }} E d$. Toronto: McGraw-Hill Ryerson Limited, 1998.

Simon Fraser University. "2008 Canadian Election Results." Accessed June 16, 2011. http://www.sfu.ca/ aheard/clections/2008-results.html

Soderlund, Walter, Walter Romanow, Donald Briggs, and Ronald Wagenberg. Media \& Elections in Canada. Toronto: Holt, Rinehart and Winston of Canada Ltd, 1984.

South African Broadcasting Corporation. "The SABC Mandate." Accessed July 25, 2011. http://www.sabc.co.za/wps/wcm/connect/41afdd8044341dal a564e 7c4173d8502/ BC Actrevised.pdf?MOD=AJPERES\&CONVERT TO=url\&CACHEID $=41$ afdd 8044341dala564e7c4173d8502.

Taras, David. "The Mass Media and Political Crisis: Reporting Canada's Constitutional Struggles." Canadian Journal of Communication 18, no. 2 (1993): 131-148.

Taylor, Charles. "Alternative Futures." In Reconciling the Solitudes, edited by Charles Taylor, and Guy Laforest. Montreal: McGill-Queens University Press, 1993.

--------. "Nationalism and the Political Intelligentsia: A Case Study." In Reconciling the 
Solitudes, edited by Charles Taylor, and Guy Laforest. Montreal: McGill-Queens Press, 1993.

Vipond, Mary. "British or American?: Canada's 'mixed' broadcasting system in the 1930s." TheRadio Journal - International Studies in Broadcast and Audio Media 2 no. 2, (2004): 89-100.

"One Network or Two? French-Language Programming on the Canadian Radio Broadcasting Commission, 1932-36." The Canadian Historical Review 89, no. 3 (September 2008): 319-343.

------. The Mass Media in Canada $3^{\prime d}$ Ed. Toronto: James Lorimer \& Co. Ltd, 2000

Waddell, Christopher. "The Campaign in the Media 2008." In The Canadian Federal Election of 2008, edited by Jon H. Pammett, and Christopher Dornan, 217-256. Toronto: Dundurn Press, 2009.

Waddell, Christopher and Christopher Dornan. "The Media and the Campaign." In The Canadian Federal Election of 2006, edited by Jon H. Pammett and Christopher Dornan, 220-252. Toronto: Dundurn Press, 2006.

Wells, Paul. Right Side Up: The Fall of Paul Martin and the Rise of Stephen Harper's New Conservatism. Toronto: McClelland \& Stewart, 2006.

Young, David. "Discourses on Communication Technologies in Canadian and European Broadcasting Policy Debates." European Journal of Communication 18 (2003): 209-240.

\section{Articles/Press Releases}

CBC Corporate Affairs. "CBC's election coverage grabs and holds Canadians' attention," October 16, 2008. Canada News Wire. Accessed October 24,2008. http:/www.newswire.ca/en/relcases/archive/October2008/16/c6763.html

Hébert, Chantal. "Tories' Quebec bid in shambles." The Toronto Star, October 8, 2008. Accessed October 27, 2008.

http://www.thestar.com/comment/columnists/article/513822

Laghi, Brian and Campbell Clark and Karen Howlett. "Harper stands by Ritz despite 'tasteless' jokes." The Globe and Mail, September 18, 2008. Accessed June 30, 2011. http://www.theglobeandmail.com/news/politics/article710865.ecc

Lessard, Denis. “Stephen Harper en chute au Québec.” La Presse ${ }_{2}$ October 10, 2008. Accessed October 27, 2008. http://www.cyberpresse.ca/actualites/elections2008/enjcux/sondages/200810/10/01-28193-stephen-harper-en-chute-auquebec.php 
MacDonald, L. Jan. "The wooing of Quebcc will recommence at dawn." The National Post, October 16, 2008. Accessed October 27, 2008.

http://network.nationalpost.com/np/blogs/fullcomment/archive/2008/10/16/l-ianmacdonald-the-wooing-of-quebec-will-recommence-at-dawn.aspx

Maich, Steve. "CBC's Split Personality," Maclean's, August 30, 2005. Accessed October 20,2008

http://www.macleans.ca/culture/media/article.jsp?content $=20050905111641 \quad 11$ $\underline{1641}$

Pratte, André. “M. Harper doit changer." La Presse, October 15, 2008. Accessed October 27, 2008.

http://www.cyberpresse.ca/opinions/editorialistes/andre -pratte/200810/15/01-

29480-m-harper-doit-changer.php

"Aucune parti n'est à la hauteur," La Presse October 9, 2008. Accessed October 27, 2008. http:/www.cyberpresse.ca/opinions/cditorialistes/andrepratte/200810/09/01-27866-aucun-parti-nest-a-la-hauteur.php

Simpson, Jeffrey. "All that wooing, but will it win Quebec's heartland?" Globe and Mail October 3, 2008. Accessed October 28, 2008.

http://www.theglobeandmail.com/scrvlet/story/RTGAM.20081003.wcosimp04/B NStory/specialComment/

Strachan, Alex. "News Ratings." TV Guys Guide to Good TV. Accessed July 25, 2011. http://communities.canada.com/shareit/blogs/tvguy/archive/2009/10/07/newsratings-score-it-ctv-lloyd-roberston-1-cbc-peter-mansbridge-0-under-new-ratingsmeasurement-system.aspx

Therrien, Richard. "Debat des chefs." Cyberpresse. April 14, 2011. Accessed August 11, 2011. http:/blogues.cyberpresse.ca/therricn/2011/04/14/debat-des-chefsbaisse-dauditoire/

“Élection, la victoire à TVA." Le Blogue de Richard Therrien. May 3, 2011. Accessed June 15, 2011. http://blogues.cyberpresse.ca/therrien/category/cotes-decoute/page/2/

-.-.-.... "Prix Gémeaux: les artistes enragé comme Harper." Le Soleil, 15 September 2008. Accessed July 15, 2011, http://www.cyberpresse.ca/le-soleil/arts-etspectacles/television-ct-radio/200809/15/01-21278-prix-gemeaux-les-artistesenrages-comme-harper.php

“À la conquête du Québec.” Radio-Canada. September 7, 2008. Accessed June 11, 2011. http://www.radio-canada.ca/nouvelles/Politique/2008/09/07/003-ElectionsHarper.shtml?ref=rss 
"CBC's election coverage grabs and holds Canadians' attention." CNW. Accessed June 15, 2011. http:/www.newswire.ca/en/releases/archive/October2008/16/c6763.html.

"Harper must manage rising anti-Quebec backlash: How many times have we heard the question: What does Quebec want?" Victoria Times Colonist, October 22, 2008. Accessed July 20, 2011.

http://www.canada.com/victoriatimescolonist/columnists/story.html? id $=53 \mathrm{fc} 2 \mathrm{f} 65$ 0b46-4159-badb-a160afc677c0

"Harper 'very pleased' with stronger minority." CBC.ca. Accessed June 11, 2011. http://www.cbc.ca/news/canada/story/2008/10/15/clexn-wedncsday.html.

"Radical bailout plan has a jawdropping price tag." American Press, September 19, 2008. Accessed July 17, 2011. http://www.allstocks.com/stockmessageboard/cgibin/ultimatcbb.cgi? ubb $=$ get topic; $\mathrm{f}=14 ; \mathrm{t}=004663 ; \mathrm{p}=1$

"Top court won't hear fixed election date case." CBC.ca. January 20, 2011. Accessed June 8, 2011. http://www.cbc.ca/news/canada/story/2011/01/20/fixed-electionscoc.html

"What would PM do with majority?" The Toronto Star, September 13, 2008. Accessed June 5, 2011. http://www.angus-reid.com/wp-content/uploads/archived$\mathrm{pdf} / \mathrm{star}$ majority.pdf

YouTube. "Culture in Danger (Culture en Peril with subtitles)." Accessed June 11, 2011. http://www.youtube.com/watch?v=Uhgv85m852Q,

\section{Television Program}

CBC The National nightly episodes from September $7^{\text {th }}$ to Oct 15, 2008.

SRC Le Telejournal nightly episodes from September $7^{\text {th }}$ to Oct $15^{\mathrm{t}}, 2008$.

SRC Le Debat, Election 2008, Live French language Election 2008 debate, Recorded on SRC's main network, Oct 2, 2008.

CBC Election Debate 2008, Live English language Election 2008 debate, Recorded Oct 2, 2008.

CTV CTV National News episode from Sept 19, 2008

TVA Le Grand Soir, episode from Sept 19, 2008. 


\section{Formal Interviews}

Michel C. Auger, Radio-Canada, Journalist, Montreal

Christian Bourque, Léger Marketing, Pollster, Montreal.

Chantal Hébert, The Toronto Star, Montreal

Daniel L'Heureux, Radio-Canada, Journalist, retired, Ottawa

Hubert Lacroix, President/CEO CBC/Radio-Canada

L. Ian MacDonald, Columnist, Telephone

Julie Van Dusen, CBC, Journalist, Ottawa

Marc-André Viau, Communications Director, NDP, Ottawa.

Nancy Wood, CBC, Journalist. Montreal 